\title{
Article \\ Identification and Characterization of Leaf-Inhabiting Fungi from Castanea Plantations in China
}

\author{
Ning Jiang $\mathbb{D}^{\mathbb{B}}$, Xinlei Fan and Chengming Tian * \\ The Key Laboratory for Silviculture and Conservation of Ministry of Education, Beijing Forestry University, \\ Beijing 100083, China; 13146723574@163.com (N.J.); xinleifan@bjfu.edu.cn (X.F.) \\ * Correspondence: chengmt@bjfu.edu.cn
}

check for updates

Citation: Jiang, N.; Fan, X.; Tian, C. Identification and Characterization of Leaf-Inhabiting Fungi from Castanea Plantations in China. J. Fungi 2021, 7, 64. https://doi.org/10.3390/ jof7010064

Received: 22 December 2020

Accepted: 15 January 2021

Published: 18 January 2021

Publisher's Note: MDPI stays neutral with regard to jurisdictional claims in published maps and institutional affiliations.

Copyright: (C) 2021 by the authors. Licensee MDPI, Basel, Switzerland. This article is an open access article distributed under the terms and conditions of the Creative Commons Attribution (CC BY) license (https:// creativecommons.org/licenses/by/ $4.0 /)$.

\begin{abstract}
Two Castanea plant species, C. henryi and C. mollissima, are cultivated in China to produce chestnut crops. Leaf spot diseases commonly occur in Castanea plantations, however, little is known about the fungal species associated with chestnut leaf spots. In this study, leaf samples of $C$. henryi and C. mollissima were collected from Beijing, Guizhou, Hunan, Sichuan and Yunnan Provinces, and leaf-inhabiting fungi were identified based on morphology and phylogeny. As a result, twenty-six fungal species were confirmed, including one new family, one new genus, and five new species. The new taxa are Pyrisporaceae fam. nov., Pyrispora gen. nov., Aureobasidium castaneae sp. nov., Discosia castaneae sp. nov., Monochaetia castaneae sp. nov., Neopestalotiopsis sichuanensis sp. nov. and Pyrispora castaneae sp. nov.
\end{abstract}

Keywords: Castanea henryi; C. mollissima; Diaporthales; phylogeny; Sporocadaceae; taxonomy

\section{Introduction}

Castanea, a plant genus well-known for edible chestnuts and hard timber, is distributed worldwide. The most four famous species are American chestnut (C. dentata), Chinese chestnut (C. mollissima), European chestnut (C. sativa) and Japanese chestnut (C. crenata). C. mollissima is widely cultivated as the crop in most provinces of China. In recent years, another Castanea species, C. henryi, was planted in Hunan Province of China to replace C. mollissima for its higher economic benefits.

In the long cultivation history of chestnut trees, fungal diseases have caused serious economic and ecological problems. Chestnut blight caused by Cryphonectria parasitica is the most notorious one, which devasted Castanea dentata forests in North America and weakened the other chestnut species in plantations [1-3]. Several emerging pathogens were recently reported in Castanea sativa from Australia and Europe, viz. Gnomoniopsis smithogilvyi (syn. G. castaneae) [4,5], Phytophthora cinnamomi [6], Sirococcus castanea [7].

In China, previous studies have revealed a high fungal diversity associated with chestnut branch cankers. For example, three Coryneum species [8], two Cryphonectria species [2], six Cytospora species and seven Dendrostoma species were described from the cankered branches [9,10]. In addition, some cryptic species were discovered, such as Aurantiosacculus castaneae [2], Endothia chinensis [2], Melanops castaneicola and Neopseudomelanconis castaneae [11,12]. Due to the high fungal diversity on chestnut branches, we collected leaf samples from two chestnut species, Castanea henryi and C. mollissima in China. In the present study, fungal taxa associated with the symptomatic leaves were identified based on morphological and molecular approaches, which is a fundamental task for the subsequent research on chestnut leaf diseases.

\section{Materials and Methods \\ 2.1. Field Sampling and Isolation}

From 2017 to 2020, we investigated Castanea plantations of C. henryi and C. mollissima in the Beijing, Guizhou, Hunan, Sichuan and Yunnan Provinces of China. The disease 
symptoms were recorded (Figure 1), and 176 fresh leaf samples were collected and packed in sealed plastic bags. These leaf samples were transported to the laboratory for fungal isolation within ten days.

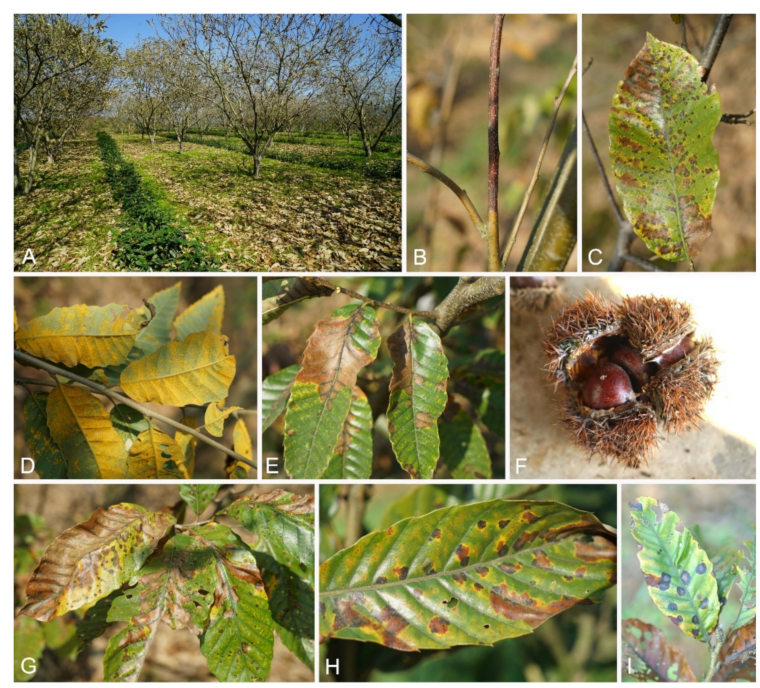

Figure 1. Field Sampling. (A) A Castanea plantation; (B) Symptoms of twig canker; (C-E,G-I) Symptoms of leaf diseases; (F) Chestnuts.

Fresh isolates were acquired by removing spore masses in fruiting bodies or surfacesterilized leaf tissues onto the surfaces of potato dextrose agar (PDA; $200 \mathrm{~g}$ potatoes, $20 \mathrm{~g}$ dextrose, $20 \mathrm{~g}$ agar per $\mathrm{L}$ ) using axenic syringe needles. Then plates were incubated in the dark at $25^{\circ} \mathrm{C}$ until germination. Hyphal tips were cut and transported to new PDA plates, and incubated in the dark at $25^{\circ} \mathrm{C}$.

\subsection{Morphological Identification and Characterization}

Fungal species on Chinese chestnut leaves were initially observed based on ascomata and conidiomata formed on the leaf surface or PDA, under a dissecting stereomicroscope (AZ100, Nikon, Tokyo, Japan), then asci, ascospores, conidiogenous cells and conidia were photographed using a Leica compound microscope (DM 2500, Leica, Wetzlar, Germany). Cultural characteristics of isolates incubated on PDA in the dark at $25^{\circ} \mathrm{C}$ were recorded.

\subsection{DNA Extraction, Sequencing and Phylogenetic Analysis}

Genomic DNA was extracted from mycelium grown on PDA using a CTAB (cetyltrime thylammonium bromide) method [13]. Then PCR (polymerase chain reaction) was conducted for each genus using selected genes and primers (Table 1). The PCR conditions were set as follows: an initial denaturation step of $5 \mathrm{~min}$ at $94{ }^{\circ} \mathrm{C}$ followed by 35 cycles of $30 \mathrm{~s}$ at $94{ }^{\circ} \mathrm{C}, 50 \mathrm{~s}$ at $52{ }^{\circ} \mathrm{C}$ (ITS, LSU) or $54{ }^{\circ} \mathrm{C}$ (act, cal, chs-1, gapdh, his3, rpb2, tub2, tef1) and $1 \mathrm{~min}$ at $72{ }^{\circ} \mathrm{C}$, and a final elongation step of $7 \mathrm{~min}$ at $72{ }^{\circ} \mathrm{C}$. The PCR amplification products were sequenced using an ABI PRISM ${ }^{\circledR}$ 3730XL DNA Analyzer with BigDye ${ }^{\circledR}$ Terminater Kit v.3.1 (Invitrogen) at the Shanghai Invitrogen Biological Technology Company Limited (Beijing, China).

The sequences obtained in this study (Table 2) were supplemented with the additional sequences retrieved from GenBank. The sequences were aligned and checked manually using MEGA6. Ambiguous regions were excluded from the analyses and gaps were treated as missing data. Phylogenetic analyses were carried out with maximum likelihood analysis (ML), which was performed at the CIPRES web portal [14]. Bayesian inference analysis (BI) was performed in MrBayes v. 3.2.0 [15]. Phylogenetic trees were viewed in FigTree v1.4. The names of the isolates from present study are marked in blue in the trees. Maximum likelihood bootstrap support values $\geq 50 \%$ (BT) and Bayesian posterior probabilities $\geq 0.90(\mathrm{PP})$ are given at the nodes respectively. 
Table 1. Selected genes and primers for polymerase chain reaction of each genus.

\begin{tabular}{|c|c|c|c|c|c|c|c|c|c|c|}
\hline Genera & ITS [16] & LSU [16] & act [17] & cal [17] & chs-1 [17] & gapdh $[18,19]$ & his3 $[20,21]$ & $r p b 2$ [22] & tef1 [17] & $t u b 2[20]$ \\
\hline Aplosporella & ITS1/ITS4 & & & & & & & & EF1-688F/EF1-1251R & \\
\hline Arthrinium & ITS1/ITS4 & & & & & & & & & \\
\hline Aureobasidium & ITS1/ITS4 & LR0R/LR5 & & & & & & & & \\
\hline Bartalinia pini & ITS1/ITS4 & LR0R/LR5 & & & & & & & & \\
\hline Botryosphaeria & ITS1/ITS4 & & & & & & & & EF1-688F/EF1-1251R & TI/BT2B \\
\hline Colletotrichum & ITS1/ITS4 & & $\begin{array}{c}\text { ACT-512F/ACT- } \\
783 \mathrm{R}\end{array}$ & & $\begin{array}{c}\text { CHS-79F/CHS- } \\
345 \mathrm{R}\end{array}$ & GDF/GDR & & & & $\mathrm{TI} / \mathrm{BT} 2 \mathrm{~B}$ \\
\hline Coniella & ITS1/ITS4 & & & & & & & & EF1-688F/EF1-1251R & \\
\hline Diaporthe & ITS1/ITS4 & & & $\begin{array}{c}\text { CAL- } \\
\text { 228F/CAL-737R }\end{array}$ & & & CYLH4F/H3-1b & & EF1-688F/EF1-1251R & $\mathrm{TI} / \mathrm{BT} 2 \mathrm{~B}$ \\
\hline Didymella & ITS1/ITS4 & LR0R/LR5 & & & & & & $\begin{array}{c}\text { RPB2- } \\
\text { 5F2/RPB2-7CR }\end{array}$ & & $\mathrm{TI} / \mathrm{BT} 2 \mathrm{~B}$ \\
\hline Discosia & ITS1/ITS4 & LR0R/LR5 & & & & & & & & TI/BT2B \\
\hline Gnomoniopsis & ITS1/ITS4 & & & & & & & & EF1-688F/EF1-1251R & TI/BT2B \\
\hline Monochaetia & ITS1/ITS4 & LR0R/LR5 & & & & & & $\begin{array}{c}\text { RPB2- } \\
\text { 5F2/RPB2-7CR }\end{array}$ & EF1-688F/EF1-1252R & $\mathrm{TI} / \mathrm{BT} 2 \mathrm{~B}$ \\
\hline Neopestalotiopsis & ITS1/ITS4 & & & & & & & & EF1-688F/EF1-1253R & TI/BT2B \\
\hline Phyllosticta & ITS1/ITS4 & & $\begin{array}{c}\text { ACT-512F/ACT- } \\
783 \mathrm{R}\end{array}$ & & & $\begin{array}{c}\text { Gpd1- } \\
\text { LM/Gpd2-LM }\end{array}$ & & & & \\
\hline Pyrispora & ITS1/ITS4 & LR0R/LR5 & & & & & & $\begin{array}{c}\text { RPB2- } \\
\text { 5F2/RPB2-7CR }\end{array}$ & EF1-688F/EF1-1254R & \\
\hline Robillarda & ITS1/ITS4 & LR0R/LR5 & & & & & & $\begin{array}{c}\text { RPB2- } \\
\text { 5F2/RPB2-7CR }\end{array}$ & EF1-688F/EF1-1255R & $\mathrm{TI} / \mathrm{BT} 2 \mathrm{~B}$ \\
\hline Tubakia & ITS1/ITS4 & & & & & & & & EF1-688F/EF1-1256R & TI/BT2B \\
\hline
\end{tabular}


Table 2. Isolates and GenBank accession numbers of sequences from this study.

\begin{tabular}{|c|c|c|c|c|c|c|c|c|c|c|c|}
\hline \multirow{2}{*}{ Species } & \multirow{2}{*}{ Isolates } & \multicolumn{10}{|c|}{ GenBank Accession No. } \\
\hline & & ITS & LSU & act & cal & chs-1 & gapdh & his3 & $r p b 2$ & tef1 & $t u b 2$ \\
\hline Aplosporella prunicola & CFCC $54334=$ SM18B & MW350059 & NA & NA & NA & NA & NA & NA & NA & MW381858 & NA \\
\hline Aplosporella prunicola & SM18B-1 & MW350060 & NA & NA & NA & NA & NA & NA & NA & MW381859 & NA \\
\hline Arthrinium arundinis & XT18-1 & MW364286 & NA & NA & NA & NA & NA & NA & NA & NA & NA \\
\hline $\begin{array}{l}\text { Aureobasidium castaneae } \\
\text { sp. nov. }\end{array}$ & CFCC $54591=$ JJ7-3 & MW364284 & MW364275 & NA & NA & NA & NA & NA & NA & NA & NA \\
\hline Bartalinia pini & CFCC $54574=$ JJ4 & MW364285 & MW364276 & NA & NA & NA & NA & NA & NA & NA & NA \\
\hline Botryosphaeria dothidea & $\mathrm{JJ} 2 \mathrm{~B}$ & MW350061 & NA & NA & NA & NA & $\mathrm{NA}$ & NA & NA & MW381860 & MW381864 \\
\hline Botryosphaeria dothidea & CFCC $54576=$ JJ12 & MW350062 & NA & NA & NA & NA & NA & NA & NA & MW381861 & MW381865 \\
\hline Botryosphaeria dothidea & $\mathrm{JJ} 14$ & MW350063 & NA & NA & NA & NA & $\mathrm{NA}$ & NA & NA & MW381862 & MW381866 \\
\hline Botryosphaeria dothidea & JJ27-1 & MW350064 & NA & NA & NA & NA & NA & NA & NA & MW381863 & MW381867 \\
\hline Colletotrichum fructicola & SM6 & MW217249 & NA & MW227352 & NA & MW227370 & MW381824 & NA & NA & NA & MW227388 \\
\hline Colletotrichum fructicola & SM9 & MW217250 & NA & MW227353 & NA & MW227371 & MW381825 & NA & NA & NA & MW227389 \\
\hline Colletotrichum fructicola & CFCC $54363=$ SM13 & MW217251 & NA & MW227354 & NA & MW227372 & MW381826 & NA & NA & NA & MW227390 \\
\hline Colletotrichum fructicola & SM16 & MW217252 & NA & MW227355 & NA & MW227373 & MW381827 & NA & NA & NA & MW227391 \\
\hline Colletotrichum fructicola & SM30 & MW217253 & NA & MW227356 & NA & MW227374 & MW381828 & NA & $\mathrm{NA}$ & NA & MW227392 \\
\hline Colletotrichum henanense & CFCC $54364=$ SM12 & MW217255 & NA & MW227358 & NA & MW227376 & MW381830 & NA & NA & NA & MW227394 \\
\hline Colletotrichum henanense & SM22 & MW217256 & NA & MW227359 & NA & MW227377 & MW381831 & NA & NA & NA & MW227395 \\
\hline Colletotrichum henanense & SM33 & MW217257 & NA & MW227360 & NA & MW227378 & MW381832 & NA & NA & NA & MW227396 \\
\hline Colletotrichum henanense & ZX2-1 & MW217258 & NA & MW227361 & NA & MW227379 & MW381833 & NA & NA & NA & MW227397 \\
\hline Colletotrichum jiangxiense & SM21 & MW217259 & NA & MW227362 & NA & MW227380 & MW381834 & NA & NA & NA & MW227398 \\
\hline Colletotrichum jiangxiense & CFCC 54362 = ZX10-1 & MW217260 & NA & MW227363 & NA & MW227381 & MW381835 & NA & NA & $\mathrm{NA}$ & MW227399 \\
\hline Colletotrichum jiangxiense & $\mathrm{ZY} 12 \mathrm{~B}$ & MW217261 & NA & MW227364 & NA & MW227382 & MW381836 & NA & NA & NA & MW227400 \\
\hline Colletotrichum jiangxiense & $\mathrm{ZY} 12$ & MW217262 & NA & MW227365 & NA & MW227383 & MW381837 & NA & NA & NA & MW227401 \\
\hline Colletotrichum karsti & CFCC $54365=$ ZY3B & MW217263 & NA & MW227366 & NA & MW227384 & MW381838 & NA & NA & NA & NA \\
\hline Colletotrichum karsti & ZY3B-1 & MW217264 & NA & MW227367 & NA & MW227385 & MW381839 & NA & NA & NA & NA \\
\hline
\end{tabular}


Table 2. Cont.

\begin{tabular}{|c|c|c|c|c|c|c|c|c|c|c|c|}
\hline \multirow{2}{*}{ Species } & \multirow{2}{*}{ Isolates } & \multicolumn{10}{|c|}{ GenBank Accession No. } \\
\hline & & ITS & LSU & act & cal & chs-1 & gapdh & his3 & $r p b 2$ & tef1 & $t u b 2$ \\
\hline Colletotrichum nymphaeae & CFCC 54366 = SM26 & MW217265 & NA & MW227368 & NA & MW227386 & MW381840 & NA & NA & NA & MW227402 \\
\hline Colletotrichum nymphaeae & SM26-1 & MW217266 & NA & MW227369 & NA & MW227387 & MW381841 & NA & NA & NA & MW227403 \\
\hline Coniella castaneicola & CFCC 54344 = ZY7-1 & MW208111 & NA & NA & NA & NA & NA & NA & NA & MW227343 & NA \\
\hline Coniella castaneicola & ZY7-2 & MW208112 & NA & NA & NA & NA & NA & NA & NA & MW227344 & NA \\
\hline Diaporthe lithocarpi & CFCC $54573=$ JJ3 & MW364281 & NA & NA & MW381842 & NA & NA & MW381845 & NA & MW381848 & MW381851 \\
\hline Diaporthe lithocarpi & JJ3-2 & MW364282 & NA & NA & MW381843 & NA & NA & MW381846 & NA & MW381849 & MW381852 \\
\hline Didymella coffeae-arabicae & CFCC 54343 = SM24 & MW364357 & MW364277 & NA & NA & NA & NA & NA & MW381854 & NA & MW381856 \\
\hline Didymella coffeae-arabicae & SM24B & MW364358 & MW364278 & NA & NA & NA & NA & NA & MW381855 & NA & MW381857 \\
\hline Discosia castaneae sp. nov. & CFCC 54088 = CML1 & MN842798 & MN842796 & NA & NA & NA & NA & NA & NA & & MN864778 \\
\hline Discosia castaneae sp. nov. & CML2 & MN842799 & MN842797 & NA & NA & NA & NA & NA & NA & & MN864779 \\
\hline Gnomoniopsis daii & CFCC 54345 = ZY11 & MW208113 & NA & NA & NA & NA & NA & NA & NA & MW227345 & MW218543 \\
\hline Gnomoniopsis daii & $\mathrm{ZY} 10-1$ & MW208114 & NA & NA & NA & NA & NA & NA & NA & MW227346 & MW218544 \\
\hline Gnomoniopsis daii & ZY10-3 & MW208115 & NA & NA & NA & NA & NA & NA & NA & MW227347 & MW218545 \\
\hline Gnomoniopsis daii & $\mathrm{ZY} 12 \mathrm{~A}$ & MW208116 & NA & NA & NA & NA & NA & NA & NA & MW227348 & MW218546 \\
\hline $\begin{array}{l}\text { Monochaetia castaneae sp. } \\
\text { nov. }\end{array}$ & CFCC 54354 = SM9-1 & MW166222 & MW166263 & NA & NA & NA & NA & NA & MW199737 & MW199741 & MW218515 \\
\hline $\begin{array}{l}\text { Monochaetia castaneae sp. } \\
\text { nov. }\end{array}$ & SM9-2 & MW166223 & MW166264 & NA & NA & NA & NA & NA & MW199738 & MW199742 & MW218516 \\
\hline Neopestalotiopsis asiatica & CFCC 54339 = SM32 & MW166224 & NA & NA & NA & NA & NA & NA & NA & MW199743 & MW218517 \\
\hline Neopestalotiopsis asiatica & SM7 & MW166225 & NA & NA & NA & NA & NA & NA & NA & MW199744 & MW218518 \\
\hline Neopestalotiopsis asiatica & SM8B & MW166226 & NA & NA & NA & NA & NA & NA & NA & MW199745 & MW218519 \\
\hline Neopestalotiopsis asiatica & SM11 & MW166227 & NA & NA & NA & NA & NA & NA & NA & MW199746 & MW218520 \\
\hline Neopestalotiopsis asiatica & SM19B & MW166228 & NA & NA & NA & NA & NA & NA & NA & MW199747 & MW218521 \\
\hline $\begin{array}{c}\text { Neopestalotiopsis } \\
\text { brasiliensis }\end{array}$ & CFCC $54341=$ ZY4 & MW166229 & NA & NA & NA & NA & NA & NA & NA & MW199748 & MW218522 \\
\hline $\begin{array}{l}\text { Neopestalotiopsis } \\
\text { brasiliensis }\end{array}$ & ZY4-2D & MW166230 & NA & NA & NA & NA & NA & NA & NA & MW199749 & MW218523 \\
\hline
\end{tabular}


Table 2. Cont.

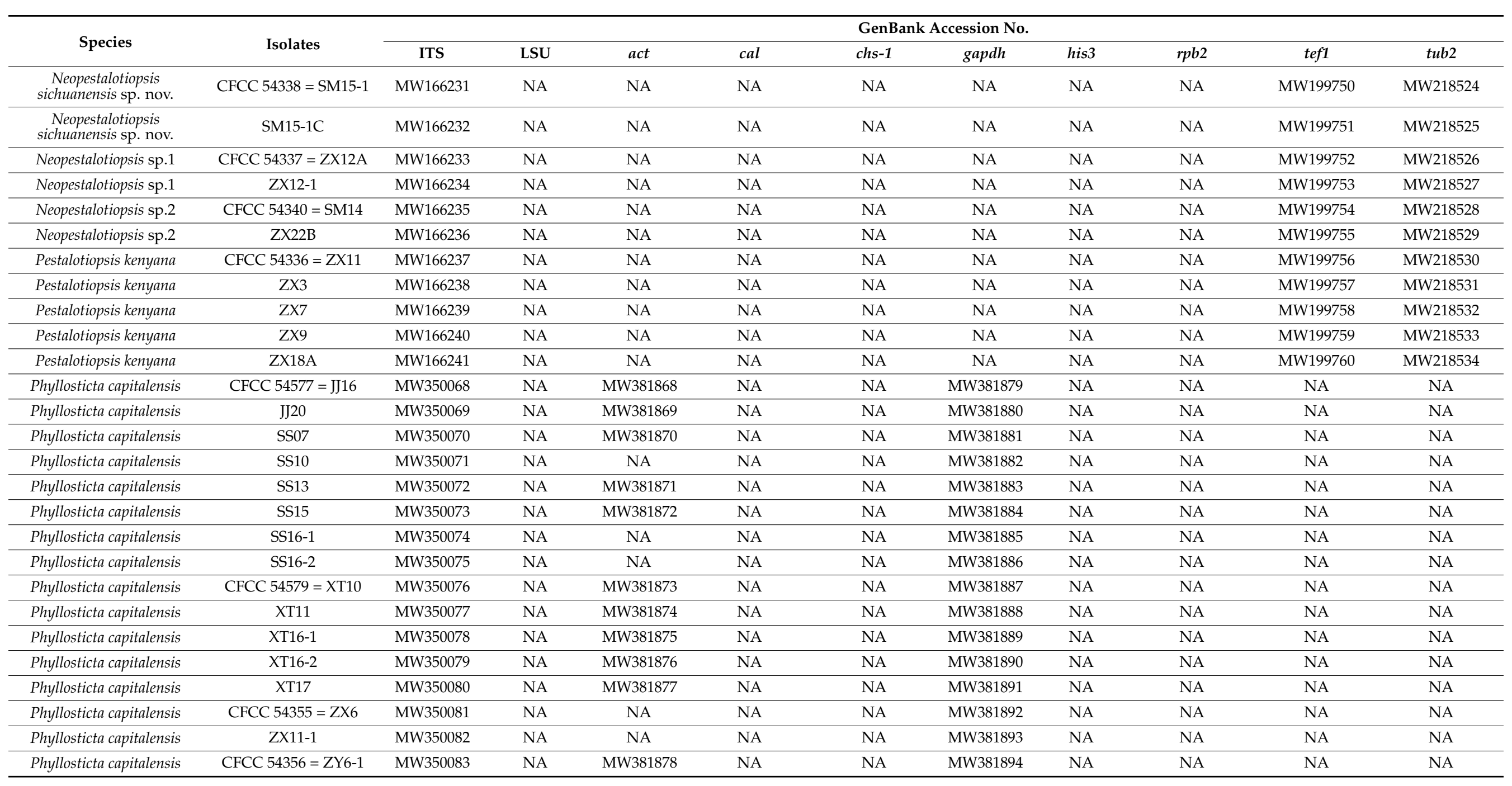


Table 2. Cont.

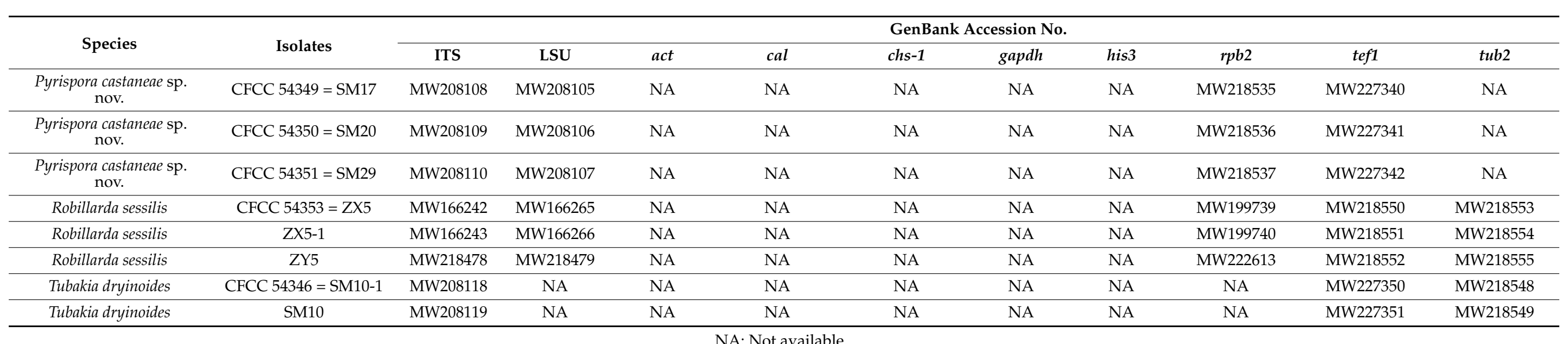

NA: Not available. 


\section{Results}

A total of 26 species were identified, which belonging to two classes, six orders, 13 families and 18 genera in Ascomycota (Table 3). The seven new taxa are Pyrisporaceae fam. nov., Pyrispora gen. nov., Aureobasidium castaneae sp. nov., Discosia castaneae sp. nov., Monochaetia castaneae sp. nov., Neopestalotiopsis sichuanensis sp. nov. and Pyrispora castaneae sp. nov.

\subsection{Aplosporella Speg.}

Aplosporella prunicola Damm \& Crous, Fungal Divers. 27(1): 39 (2007)

Endophytic or pathogenic on Castanea mollissima leaves. Sexual morph: Undetermined. Asexual morph: Undetermined.

Culture characteristics-Colonies on PDA reaching up to $60 \mathrm{~mm}$ in 5 days, flat with undulate edge, olivaceous to grey-olivaceous, aerial mycelium appressed, floccose, white to smoke-grey.

Material examined-CHINA, Sichuan Province, Yaan City, Shimian County, $29^{\circ} 13^{\prime} 31^{\prime \prime}$ $\mathrm{N}, 102^{\circ} 21^{\prime} 27^{\prime \prime} \mathrm{E}$, alt. $978 \mathrm{~m}$, on leaf spots of Castanea mollissima, 10 September 2020, N. Jiang (living culture, CFCC 54334 = SM18B); ibid. (living culture, SM18B-1).

Notes-Aplosporella prunicola was initially recorded from Prunus persica var. nucipersica in South Africa [23]. Two new isolates from diseased chestnut leaves in present study are phylogenetically close to Aplosporella prunicola (Figure A1) and share similar culture characteristics on PDA. This is the first report of this fungus on the host Castanea mollissima, and in the Country China.

\subsection{Botryosphaeria Ces. \& De Not.}

Botryosphaeria dothidea Ces. \& De Not., Comm. Soc. crittog. Ital. 1(fasc. 4): 212 (1863) (Figure 2)

Pathogenic on Castanea henryi and C. mollissima leaves. Sexual morph: Undetermined. Asexual morph: Conidiomata 100-250 $\mu \mathrm{m}$ diam., pycnidial, aggregated, globose, black. Conidiophores absent. Conidiogenous cells 3-11 × 1.5-3 $\mu \mathrm{m}$, holoblastic, discrete, hyaline, cylindrical to lageniform, phialidic with periclinal thickening. Conidia (18.3-)20-24.7(-26.4) $\times(6.3-) 7.2-8.4(-8.7) \mu \mathrm{m}(\bar{x}=22.3 \times 7.8 \mu \mathrm{m}, n=50), \mathrm{L} / \mathrm{W}=(2.3-) 2.4-3.4(-3.9)(\bar{x}=2.9, n=$ $50)$, hyaline, thin-walled, smooth with granular contents, unicellular, aseptate, ellipsoid to fusoid, base subtruncate to bluntly rounded.

Culture characteristics-Colonies on PDA reaching up to $60 \mathrm{~mm}$ in 4 days, initially white with fluffy, aerial mycelium, becoming black on the surface after 5 days; reverse side of the colonies dark-brown.

Material examined-CHINA, Hunan Province, Changsha City, Changsha County, Jinjing Town, $28^{\circ} 58^{\prime} 52^{\prime \prime} \mathrm{N}, 113^{\circ} 34^{\prime} 38^{\prime \prime} \mathrm{E}$, alt. $63 \mathrm{~m}$, on leaf spots of Castanea henryi, 10 November 2020, C.M. Tian \& N. Jiang (BJFC-S1823; living culture, JJ 2B); ibid. (living cultures, CFCC $54576=$ JJ12, JJ14, JJ27-1); Hunan Province, Shaoshan City, Yintian Town, $27^{\circ} 52^{\prime} 04^{\prime \prime} \mathrm{N}, 112^{\circ} 35^{\prime} 03^{\prime \prime} \mathrm{E}$, alt. $73 \mathrm{~m}$, on leaf spots of Castanea mollissima, 9 November 2020, C.M. Tian \& N. Jiang (living culture, CFCC 54585 = SS9-1); Beijing City, Haidian District, $40^{\circ} 00^{\prime} 30^{\prime \prime} \mathrm{N}, 116^{\circ} 20^{\prime} 26^{\prime \prime} \mathrm{E}$, alt. $23 \mathrm{~m}$, on leaf spots of Castanea mollissima, 28 August 2020, N. Jiang (BJFC-S1797).

Notes-The genus Botryosphaeria is presently not well separated phylogenetically [24-26]. In the phylogenetic inference of ITS, tef1 and tub2 sequence data (Figure A2), four new isolates from this study are close to B. auasmontanum, B. dothidea, B. minutispermatia, B. qinlingensis, $B$. sinensis and $B$. wangensis. Phylogenic analyses based on more collections of this genus are necessary to clarify species concept in the future. In present study, we provide the morphology and phylogeny of samples from Castanea leaves, and identified these isolates as Botryosphaeria dothidea s. l. 
Table 3. Fungal species from Castanea leaves.

\begin{tabular}{|c|c|c|c|c|c|c|}
\hline Phylum & Class & Order & Family & Species & Phogeny & Morphology \\
\hline \multirow{25}{*}{ Ascomycota } & \multirow{5}{*}{ Dothideomycetes } & \multirow{3}{*}{ Botryosphaeriales } & Aplosporellaceae & Aplosporella prunicola & Figure A1 & NA \\
\hline & & & Botryosphaeriaceae & Botryosphaeria dothidea & Figure A2 & Figure 2 \\
\hline & & & Phyllostictaceae & Phyllosticta capitalensis & Figure A3 & Figures 3 and 4 \\
\hline & & Dothideales & Saccotheciaceae & Aureobasidium castaneae & Figure 5 & Figure 6 \\
\hline & & Pleosporales & Didymellaceae & Didymella coffeae-arabicae & Figure A4 & Figure 7 \\
\hline & \multirow{20}{*}{ Sordariomycetes } & \multirow{10}{*}{ Amphisphaeriales } & Apiosporaceae & Arthrinium arundinis & Figure A5 & NA \\
\hline & & & \multirow{9}{*}{ Sporocadaceae } & Bartalinia pini & Figure A6 & Figure 8 \\
\hline & & & & Discosia castaneae & Figure 9 & Figure 10 \\
\hline & & & & Monochaetia castaneae & Figure 11 & Figure 12 \\
\hline & & & & Neopestalotiopsis asiatica & Figure 13 & Figure 14 \\
\hline & & & & Neopestalotiopsis brasiliensis & Figure 13 & Figure 15 \\
\hline & & & & Neopestalotiopsis sichuanensis & Figure 13 & Figure 16 \\
\hline & & & & Neopestalotiopsis sp.1 & Figure 13 & Figure 17 \\
\hline & & & & Neopestalotiopsis sp.2 & Figure 13 & Figure 18 \\
\hline & & & & Robillarda sessilis & Figure A8 & Figure 20 \\
\hline & & \multirow{5}{*}{ Diaporthales } & Diaporthaceae & Diaporthe lithocarpi & Figure A9 & Figure 21 \\
\hline & & & Gnomoniaceae & Gnomoniopsis daii & Figure A10 & Figure 22 \\
\hline & & & Pyrisporaceae & Pyrispora castaneae & Figure 23 & Figures 24 and 25 \\
\hline & & & Schizoparmaceae & Coniella castaneicola & Figure A11 & Figure 26 \\
\hline & & & Tubakiaceae & Tubakia dryinoides & Figure A12 & Figure 27 \\
\hline & & \multirow{5}{*}{ Glomerellales } & \multirow{5}{*}{ Glomerellaceae } & Colletotrichum fructicola & Figure A13 & NA \\
\hline & & & & Colletotrichum henanense & Figure A13 & NA \\
\hline & & & & Colletotrichum jiangxiense & Figure A13 & NA \\
\hline & & & & Colletotrichum karsti & Figure A14 & NA \\
\hline & & & & Colletotrichum nymphaeae & Figure A15 & NA \\
\hline
\end{tabular}




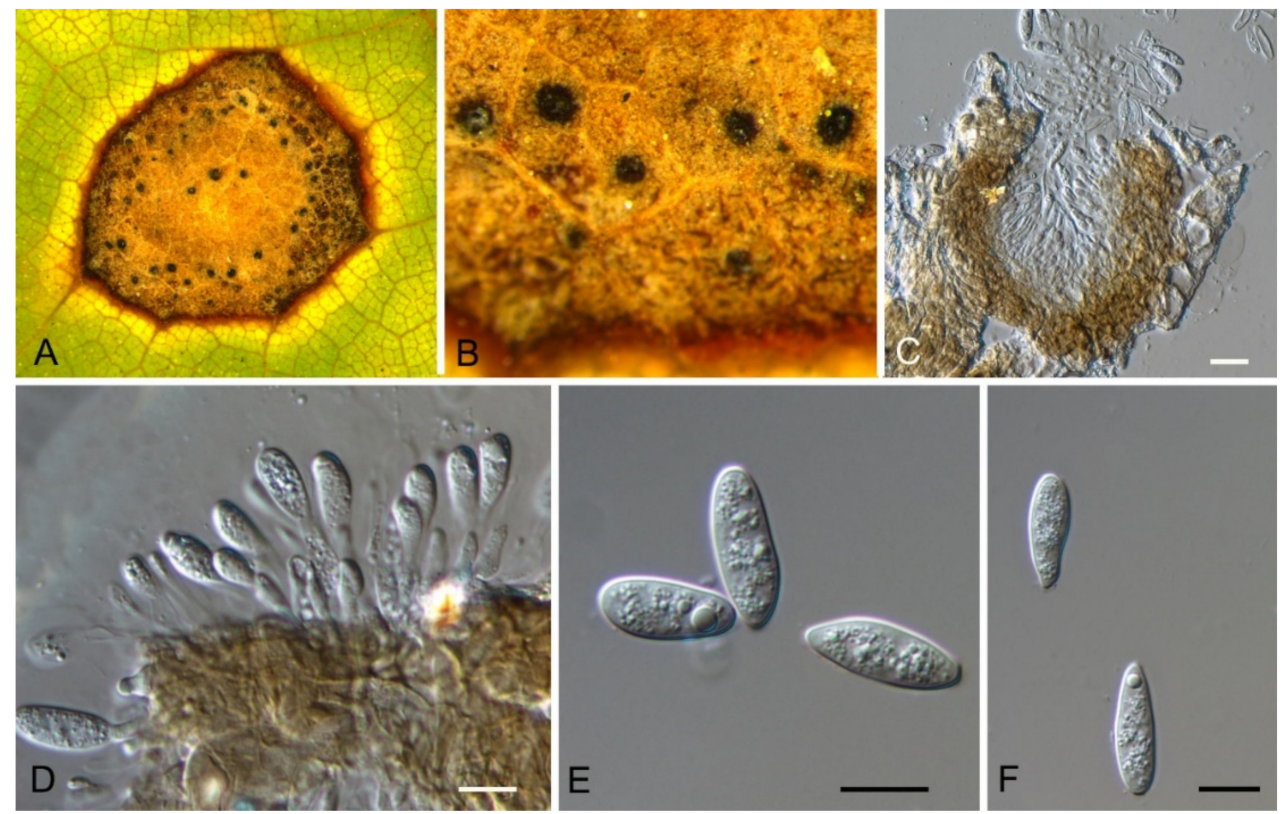

Figure 2. Botryosphaeria dothidea (BJFC-S1797). (A,B) Conidiomata on the diseased leaves of Castanea mollissima; (C) Section through the pycnidium; (D) Conidiogenous cells giving rise to conidia; $(\mathbf{E}, \mathbf{F})$ Conidia. Scale bars: $(\mathbf{C})=15 \mu \mathrm{m} ;(\mathbf{C}-\mathbf{F})=10 \mu \mathrm{m}$.

\subsection{Phyllosticta Pers.}

Phyllostictacapitalensis Henn., Hedwigia 48: 13 (1908) (Figures 3 and 4)

Pathogenic on Castanea henryi and C. mollissima leaves. Sexual morph: Ascomata 80-200 $\mu \mathrm{m}$ diam., globose to pyriform, black. Asci $62-85 \times 8-12.5 \mu \mathrm{m}$, bitunicate, clavate to broadly fusoid-ellipsoid. Ascospores (13.2-)14.6-16.2(-17.4) $\times(3.7-) 4.1-5.2(-6.8) \mu \mathrm{m}$ $(\bar{x}=15.1 \times 4.5 \mu \mathrm{m}, n=30), \mathrm{L} / \mathrm{W}=(2.8-) 2.9-4(-4.1)(\bar{x}=3.5, n=30)$, bi-seriate, hyaline, smooth, 1-septate or aseptate, guttulate, straight and slightly curved, widest in the middle, limoniform with obtuse ends, with distinct hyaline gelatinous caps at both ends, 3-5 $\times 1.5-3 \mu \mathrm{m}$. Asexual morph: Conidiomata 100-250 $\mu \mathrm{m}$ diam., pycnidial, scattered or aggregated, globose to subglobose, black. Pycnidial wall of several layers, composed of cells of textura angularis, thick, inner wall of hyaline textura angularis cells. Conidiophores reduced to conidiogenous cells. Conidiogenous cells 3-12 $\times 2.5-5.5 \mu \mathrm{m}$, terminal, subcylindrical to ampulliform to doliiform, hyaline, smooth, proliferating several times percurrently near apex. Conidia (9-)10-11.8(-12.4) $\times(6.8-) 7.4-8.3(-8.6) \mu \mathrm{m}(\bar{x}=10.9 \times 7.8 \mu \mathrm{m}, n=50)$, $\mathrm{L} / \mathrm{W}=(1.1-) 1.3-1.5(-1.6)(\bar{x}=1.4, n=50)$, solitary, hyaline, aseptate, thin and smooth walled, with a single large central guttulate, obovoid, tapering towards a narrow truncate base, enclosed in a persistent mucoid sheath, 2-7 $\mu \mathrm{m}$ thick.

Culture characteristics-Colonies on PDA reaching up to $40 \mathrm{~mm}$ in 10 days, flat, initially white-grey mycelium, gradually becoming greenish to dark brown, with white hyphae at the margin; reverse black.

Material examined-CHINA, Hunan Province, Changsha City, Changsha County, Jinjing Town, $28^{\circ} 58^{\prime} 52^{\prime \prime} \mathrm{N}, 113^{\circ} 34^{\prime} 38^{\prime \prime} \mathrm{E}$, alt. $63 \mathrm{~m}$, on leaf spots of Castanea henryi, 10 November 2020, C.M. Tian \& N. Jiang (BJFC-S1821; living culture, JJ4); ibid. (BJFCS1822; living culture, CFCC 54576 = JJ11); ibid. (living cultures, CFCC 54577 = JJ16, JJ20); Hunan Province, Shaoshan City, Yintian Town, $27^{\circ} 52^{\prime} 04^{\prime \prime} \mathrm{N}, 112^{\circ} 35^{\prime} 03^{\prime \prime} \mathrm{E}$, alt. $73 \mathrm{~m}$, on leaf spots of Castanea mollissima, 9 November 2020, C.M. Tian \& N. Jiang (BJFC-S1820; living culture, SS5); ibid. (living cultures, SS10, SS13, SS15, SS16-1, SS16-2); Hunan Province, Xiangtan City, $27^{\circ} 48^{\prime} 51^{\prime \prime} \mathrm{N}, 112^{\circ} 71^{\prime} 42^{\prime \prime} \mathrm{E}$, alt. $85 \mathrm{~m}$, on leaf spots of Castanea mollissima, 9 November 2020, N. Jiang (BJFC-S1819; living culture, XT2); ibid. (living cultures, XT10, XT11, XT16-1, XT16-2, XT17); Yunnan Province, Zhaotong City, Zhenxiong County, $27^{\circ} 43^{\prime} 28^{\prime \prime} \mathrm{N}$, 
$105^{\circ} 10^{\prime} 35^{\prime \prime} \mathrm{E}$, alt. $1280 \mathrm{~m}$, on leaf spots of Castanea mollissima, 5 September 2020, N. Jiang (living cultures, ZX6, ZX11-1); Guizhou Province, Zunyi City, Goujiang Town, $27^{\circ} 24^{\prime} 49^{\prime \prime} \mathrm{N}$, $106^{\circ} 52^{\prime} 49^{\prime \prime} \mathrm{E}$, alt. $1064 \mathrm{~m}$, on leaf spots of Castanea mollissima, 7 September 2020, N. Jiang (living culture, ZY6-1).

Notes-The genus Phyllosticta is a worldwide genus of pathogens, endophytes and saprobes, which was separated into six species complexes [27]. In the present study, we observed the sexual and asexual morphs on Castanea leaves, and identified them as Phyllosticta capitalensis s. s. based on the phylogenetic inference of ITS, LSU, act, gapdh and tef1 sequence data (Figure A3).
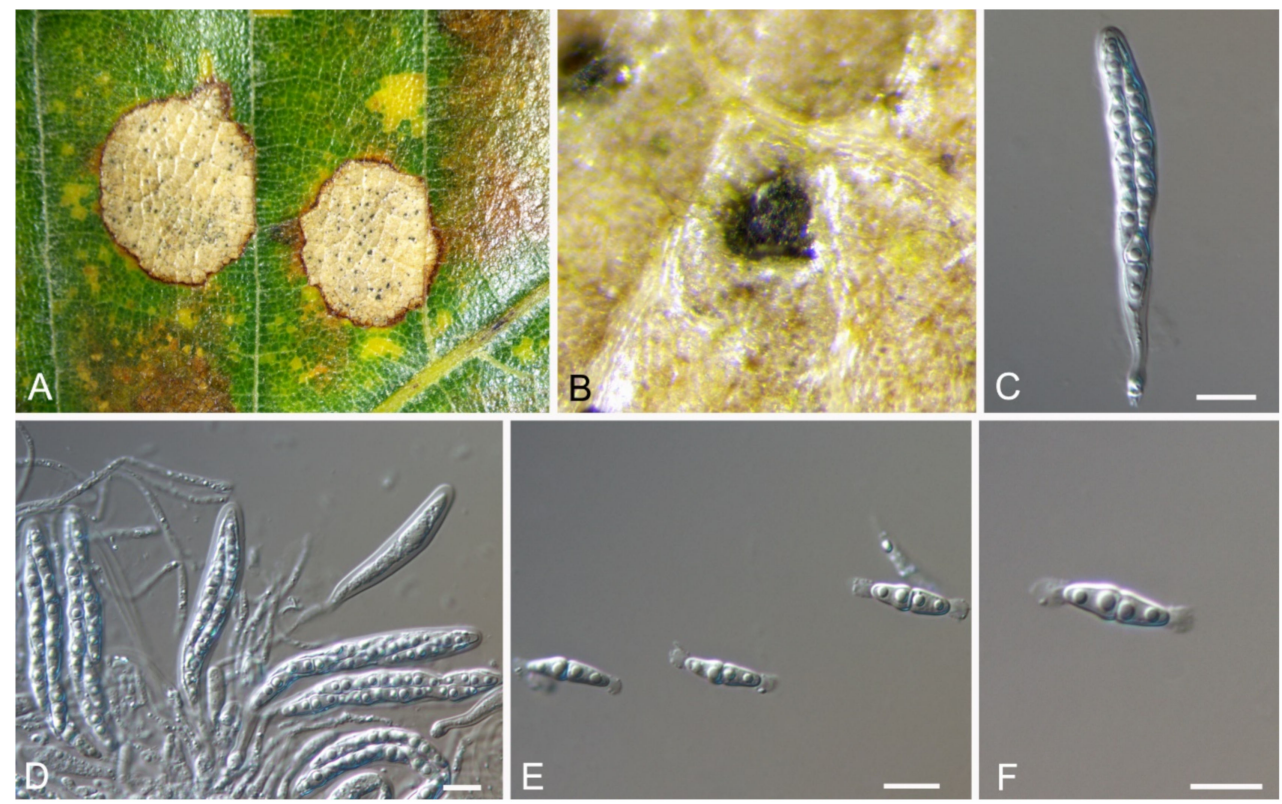

Figure 3. Phyllosticta capitalensis (BJFC-S1821). (A,B) Ascostromata on the diseased leaves of Castanea mollissima; (C,D) Asci; (E,F) Ascospores. Scale bars: $(\mathbf{C}-\mathbf{F})=10 \mu \mathrm{m}$.
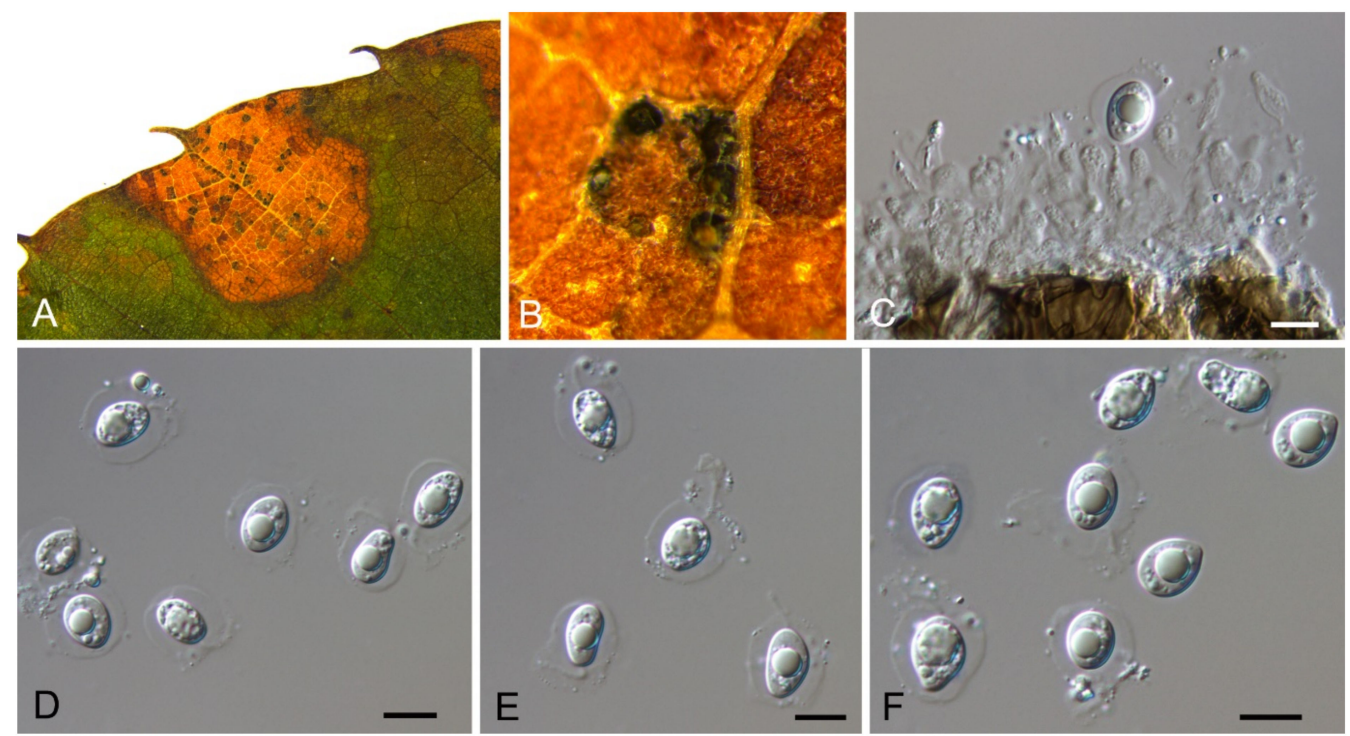

Figure 4. Phyllosticta capitalensis (BJFC-S1820). (A,B) Conidiomata on the diseased leaves of Castanea mollissima; (C) Conidiogenous cells giving rise to conidia; (D-F) Conidia. Scale bars: $(\mathbf{C}-\mathbf{F})=10 \mu \mathrm{m}$.

\subsection{Aureobasidium Viala \& G. Boyer}

Aureobasidium castaneae C.M. Tian \& N. Jiang, sp. nov. (Figure 6) 
MycoBank: MB 838314

Etymology—named after the host genus, Castanea.

Holotype-BJFC-C007

Endophytic or pathogenic on Castanea henryi leaves. Sexual morph: Undetermined. Asexual morph was observed on PDA: Mycelium immersed, no aerial mycelium. Hyphae 3-7 $\mu \mathrm{m}$ wide, smooth, thin-walled, septate, hyaline or brown. Conidiogenous cells undifferentiated, hyaline or brown, intercalary or rarely terminal. Conidia (5.9-)7.1-10.6(-11.8) $\times$ $(2.7-) 2.7-4.7(-6.2) \mu \mathrm{m}(\bar{x}=8.9 \times 3.7 \mu \mathrm{m}, n=50), \mathrm{L} / \mathrm{W}=(1.8-) 2.1-2.8(-3.1)(\bar{x}=2.4, n=50)$, hyaline or brown based on the color of conidiogenous cells, variable in size, ellipsoidal, straight, rarely slightly curved, with rounded to subtruncate base and a flat basal hilum, thin-walled, with two or more guttules.

Culture characteristics-Colonies on PDA reaching up to $40 \mathrm{~mm}$ in 7 days, spreading, smooth, flat, rapidly turning to olivaceous black, with dark green, irregular margins, covered with slimy masses of conidia.

Material examined-CHINA, Hunan Province, Changsha City, Changsha County, Jinjing Town, $28^{\circ} 58^{\prime} 52^{\prime \prime} \mathrm{N}, 113^{\circ} 34^{\prime} 38^{\prime \prime} \mathrm{E}$, alt. $63 \mathrm{~m}$, on leaf spots of Castanea henryi, 10 November 2020, C.M. Tian \& N. Jiang (BJFC-C007, holotype; ex-type living culture, CFCC 54591 = JJ 7-3).

Notes-Aureobasidium is a well-known genus comprising saprophytes, endophytes and pathogens on various substrates [28-32]. A. castaneae from Castanea henryi in this study is closely related to $A$. thailandense from unknown plants based on phylogenetic inference of ITS and LSU sequence data (Figure 5). However, A. castaneae can be easily distinguished from $A$. thailandense by conidial size $(7.1-10.6 \times 2.7-4.7 \mu \mathrm{m}$ in A. castaneae vs. 3-10 $\times 5-12 \mu \mathrm{m}$ in A. thailandense) [31].

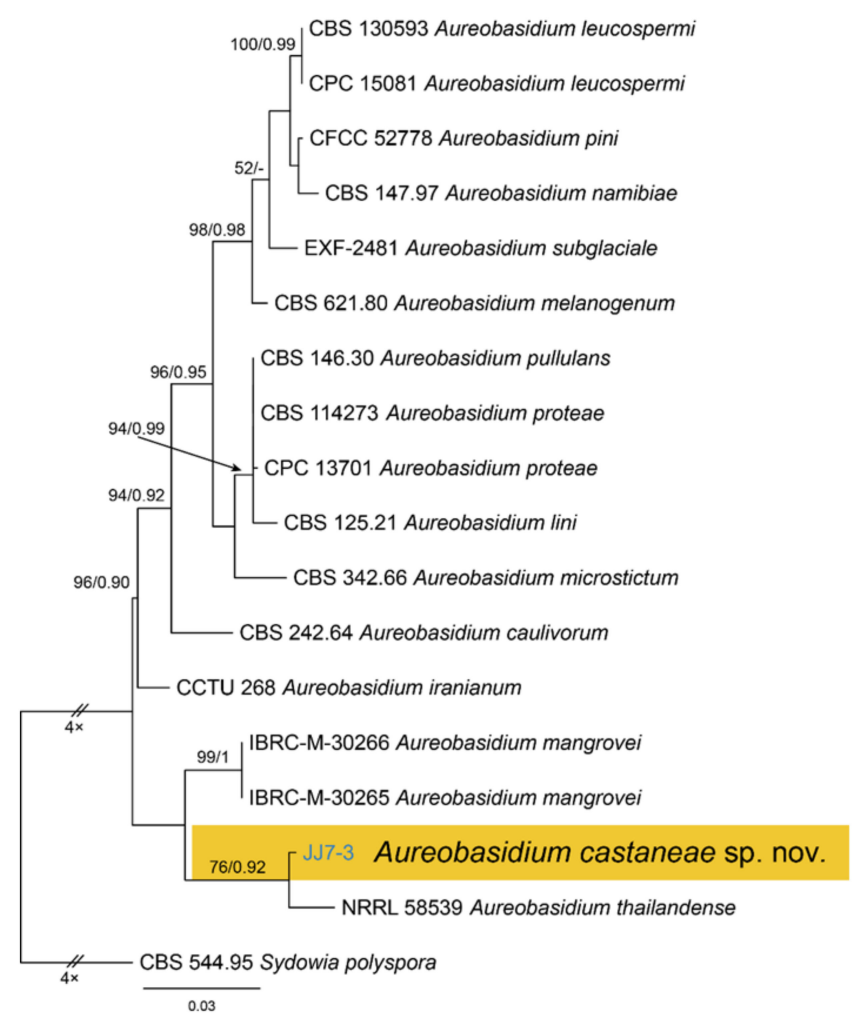

Figure 5. Phylogram generated from RAxML analysis based on combined ITS and LSU sequence data of Aureobasidium isolates. The tree was rooted to Sydowia polyspora (CBS 544.95). The scale bar indicates 0.03 nucleotide changes per site. Isolate from this study is marked in blue, and the identified species is marked in yellow. 

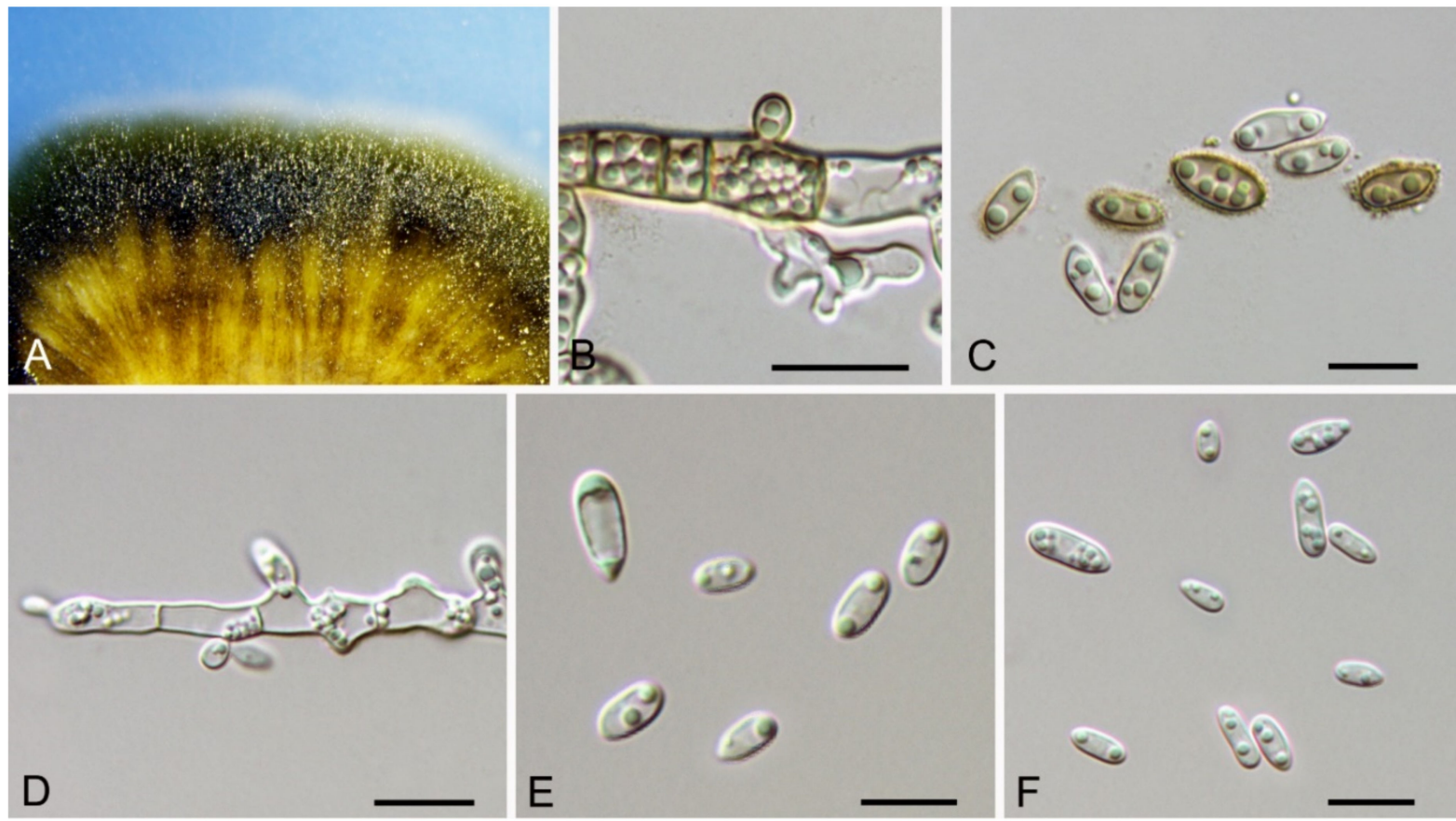

Figure 6. Aureobasidium castaneae (BJFC-C007, holotype). (A) Colony on PDA; (B,D) Conidiogenous cells and conidia; $(\mathbf{C}, \mathbf{E}, \mathbf{F})$ Conidia. Scale bars: $(\mathbf{B}-\mathbf{F})=10 \mu \mathrm{m}$.

\subsection{Didymella Sacc.}

Didymella coffeae-arabicae Qian Chen \& L. Cai, Stud. Mycol. 82: 175 (2015) (Figure 7)

Pathogenic on Castanea mollissima leaves. Sexual morph: Undetermined. Asexual morph: Conidiomata 120-200 $\mu \mathrm{m}$ diam., 100-180 $\mu \mathrm{m}$ high, pycnidial, conspicuous, stromatic, scattered or aggregated, globose to subglobose, dark brown, with septate and dark hyphal outgrowths. Ostioles single, centric. Pycnidial wall pseudoparenchymatous, composed of isodiametric cells, 3-5 layers, $8-20 \mu \mathrm{m}$ thick. Conidiogenous cells phialidic, hyaline, simple, smooth, flask-shaped to globose. Conidia (3.1-)3.7-4.8(-4.9) $\times(1.8-) 2.1-$ 2.7(-2.8) $\mu \mathrm{m}(\bar{x}=4.3 \times 2.4 \mu \mathrm{m}, n=50), \mathrm{L} / \mathrm{W}=(1.3-) 1.5-2.2(-2.6)(\bar{x}=1.8, n=50)$, ellipsoidal to ovoid, thin-walled, smooth, hyaline, always aseptate, eguttulate or with several minute apolar guttules.

Culture characteristics-Colonies on PDA reaching up to $70 \mathrm{~mm}$ in 7 days, margin regular, covered by felty aerial mycelium, olivaceous, mouse grey towards periphery, reverse dark mouse grey.

Material examined-CHINA, Sichuan Province, Yaan City, Shimian County, $29^{\circ} 13^{\prime} 31^{\prime \prime} \mathrm{N}$, $102^{\circ} 21^{\prime} 27^{\prime \prime}$ E, alt. $978 \mathrm{~m}$, on leaf spots of Castanea mollissima, 10 September 2020, N. Jiang (BJFC-S1792; living culture, CFCC 54343 = SM24); ibid. (living culture, SM24B).

Notes-Didymella is a famous pathogenic genus mainly occurring on plant leaves [33-37]. Phoma-like species are difficult to identify to the genus and species level due to a lack of good characteristics, making molecular data are essential during species identification $[34,35,37]$. The new isolates (CFCC 54343 and SM24B) from Castanea mollissima grouped with Didymella coffeae-arabicae on Coffea arabica with high statistical support (Figure A4). Our collection also shared similar morphology in conidial size with Didymella coffeae-arabicae [33]. 

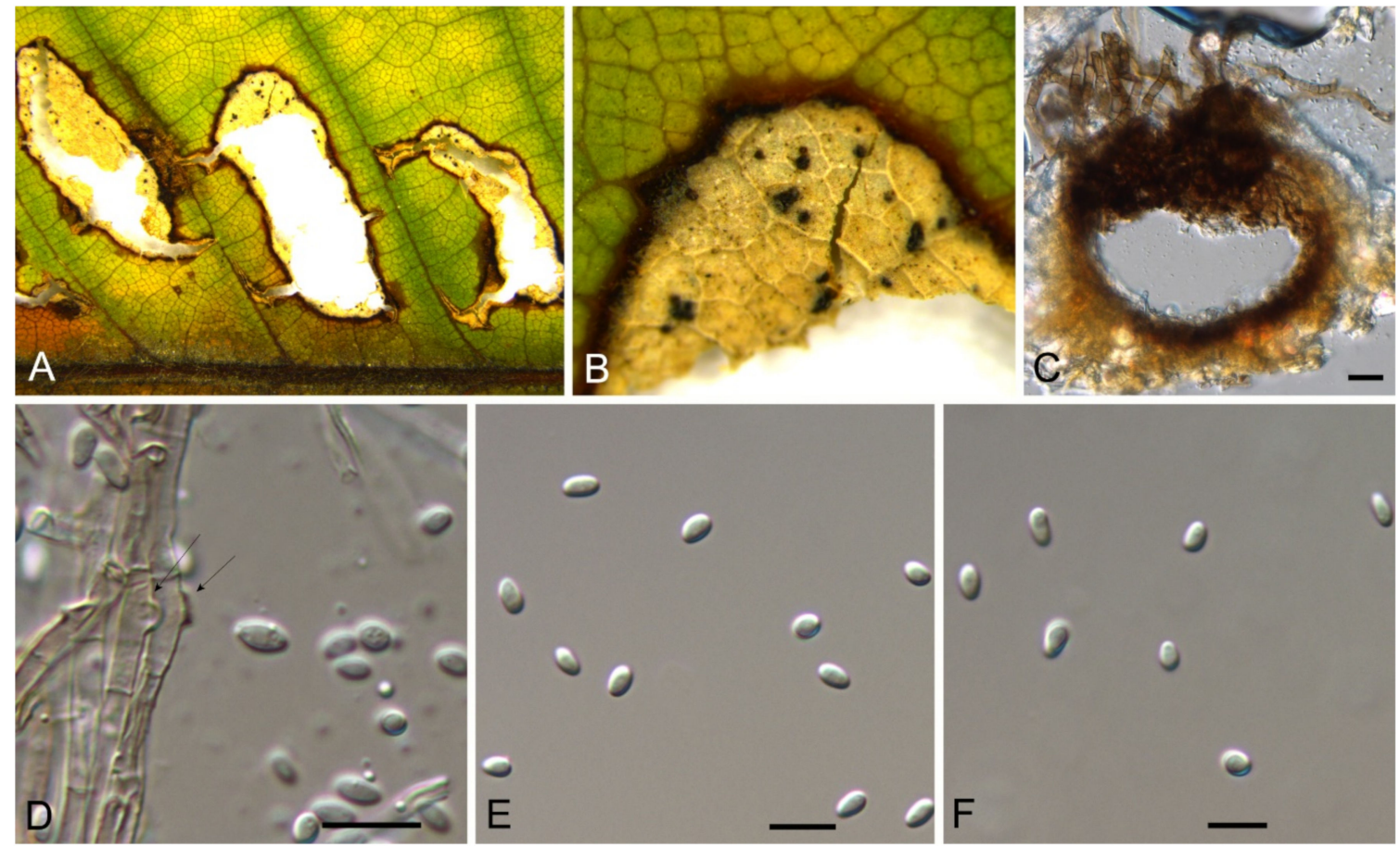

Figure 7. Didymella coffeae-arabicae (BJFC-S1792). (A,B) Conidiomata on the diseased leaves of Castanea mollissima; (C) Section through the pycnidium; (D) Conidiogenous cells giving rise to conidia (arrows); (E,F) Conidia. Scale bars: $(\mathbf{C}-\mathbf{F})=10 \mu \mathrm{m}$.

\subsection{Arthrinium Kunze}

Arthrinium arundinis (Corda) Dyko \& B. Sutton, Mycotaxon 8(1): 119 (1979)

Endophytic or pathogenic on Castanea mollissima leaves. Sexual morph: Undetermined. Asexual morph was observed on PDA: Mycelium consisting of smooth, hyaline, branched, septate, 1.5-3 $\mu \mathrm{m}$ diam hyphae. Conidiogenous cells 5.5-15 $\times 2.5-3.5 \mu \mathrm{m}$, aggregated in clusters on hyphae, pale brown, smooth, ampulliform. Conidia $3-4 \mu \mathrm{m}$ diam. $(\bar{x}=3.4 \mu \mathrm{m}$, $n=50$ ), brown, smooth, globose, with pale equatorial slit.

Culture characteristics-Colonies on PDA reaching up to $70 \mathrm{~mm}$ in 7 days, flat, spreading, covered by iron-grey aerial mycelium, reverse grey.

Material examined-CHINA, Hunan Province, Xiangtan City, $27^{\circ} 48^{\prime} 51^{\prime \prime} \mathrm{N}, 112^{\circ} 71^{\prime} 42^{\prime \prime}$ E, alt. $85 \mathrm{~m}$, on leaf spots of Castanea mollissima, 9 November 2020, N. Jiang (living culture, XT18-1).

Notes-Arthrinium is a common genus on a wide range of substrates, including soil, plant debris, plants, lichens, marine algae, and human tissues [38-42]. The new isolate (XT18-1) from Castanea mollissima grouped with A. arundinis isolates with high statistical support (Figure A5). Therefore, we identify our new isolate as A. arundinis and Castanea mollissima as a new host record for the fungus.

\subsection{Bartalinia Tassi}

Bartalinia pini F. Liu, L. Cai \& Crous, Stud. Mycol. 92: 309 (2019) (Figure 8)

Pathogenic on Castanea henryi leaves. Sexual morph: Undetermined. Asexual morph: Conidiomata 85-160 $\mu \mathrm{m}$ diam., 50-120 $\mu \mathrm{m}$ high, acervular, conspicuous, stromatic, scattered or aggregated, rounded, black. Conidiophores reduced to conidiogenous cells, septate, smooth, hyaline, invested in mucus. Conidiogenous cells $4.5-15 \times 1.5-4 \mu \mathrm{m}$, annellidic, discrete, ampulliform. Conidia (18.2-)19-21.5(-22.1) $\times(3.4-) 3.6-4.2(-4.5) \mu \mathrm{m}$ $(\bar{x}=20.1 \times 3.8 \mu \mathrm{m}, n=50), \mathrm{L} / \mathrm{W}=(4.5-) 4.7-5.9(-6.2)(\bar{x}=5.3, n=50)$, cylindrical with acute or obtuse ends, straight or slightly curved, 4 -septate, smooth; basal cell obconic with a truncate base, thin-walled, hyaline, 1.5-3.5 $\mu \mathrm{m}$ long; median cells 3, cylindrical, pale brown, each 3.5-7.5 $\mu \mathrm{m}$ long; apical cell conic with an acute apex, thin-walled, hyaline, 2-3.5 $\mu \mathrm{m}$ 
long; apical appendage with three branches, tubular, filiform, flexuous, divergent, 5-25 $\mu \mathrm{m}$ long; basal appendage tubular, unbranched, excentric, 3-8 $\mu \mathrm{m}$ long.

Culture characteristics-Colonies on PDA reaching up to $70 \mathrm{~mm}$ in 10 days, flat with entire edge, glaucous grey to grey.

Material examined-CHINA, Hunan Province, Changsha City, Changsha County, Jinjing Town, $28^{\circ} 58^{\prime} 52^{\prime \prime} \mathrm{N}, 113^{\circ} 34^{\prime} 38^{\prime \prime} \mathrm{E}$, alt. $63 \mathrm{~m}$, on leaf spots of Castanea henryi, 10 November 2020, C.M. Tian \& N. Jiang (BJFC-S1808; living culture, CFCC 54574 = JJ4).

Notes-Bartalinia is morphologically distinct from the other Sporocadaceous genera by its conidial characters [43]. The new isolate (CFCC 54574) from Castanea henryi grouped with B. pini isolates from Pinus patula (Pinaceae) needles and leaves of Acacia koa (Fabaceae) (Figure A6) and overlapped in morphology with B. pini [43]. Therefore, we identify our new isolate as B. pini, China as a new geographical record and Castanea henryi as a new host record for the fungus.
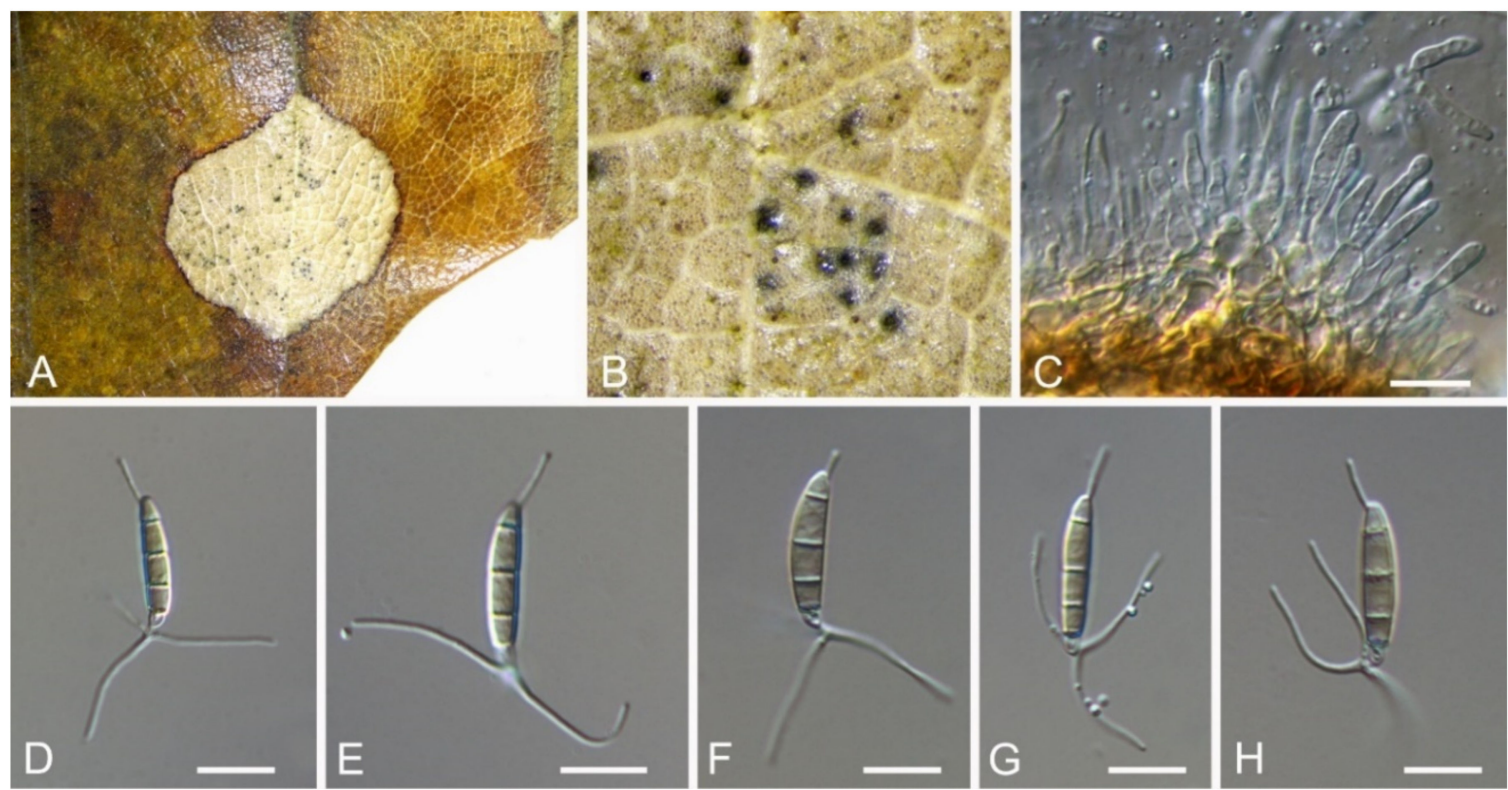

Figure 8. Bartalinia pini (BJFC-S1808). (A,B) Conidiomata on the diseased leaves of Castanea henryi; (C) Conidiogenous cells giving rise to conidia; $(\mathbf{D}-\mathbf{H})$ Conidia. Scale bars: $(\mathbf{C}-\mathbf{F})=10 \mu \mathrm{m}$.

\subsection{Discosia Lib. ex Durieu \& Mont.}

Discosia castaneae C.M. Tian \& N. Jiang, sp. nov. (Figure 10)

MycoBank: MB837794

Etymology—named for the host genus, Castanea.

Holotype-BJFC-S1805

Pathogenic on Castanea mollissima leaves. Sexual morph: Undetermined. Asexual morph: Conidiomata 100-170 $\mu \mathrm{m}$ diam., 20-40 $\mu \mathrm{m}$ high, acervular, conspicuous, stromatic, scattered or aggregated, rounded, black, glabrous, epidermal. Conidiophores absent. Conidiogenous cells 3-7 $\times 1-3 \mu \mathrm{m}$, holoblastic to phialidic, ampulliform, integrated, hyaline, smooth-walled. Conidia (14.1-)15.4-17(-18.7) $\times(2.9-) 3.1-3.8(-3.9) \mu \mathrm{m}(\bar{x}=16.2 \times 3.5 \mu \mathrm{m}$, $n=50), \mathrm{L} / \mathrm{W}=(3.9-) 4.2-5.3(-5.5)(\bar{x}=4.8, n=50)$, cylindrical to allantoid, initially hyaline, becoming pale brown at maturity, smooth-walled, guttulate, 3-euseptate, slightly constricted at septa, thin-walled; with basal cell obconic, slightly truncate at the base and appendaged; 2 median cells subcylindrical, with second cell from the base 5-8 $\mu \mathrm{m}$ long and third cell 3-6 $\mu \mathrm{m}$ long; apical cell subconical with a obtuse apex; apical and basal cells each with a single, simple, unbranched, filamentous appendage at the ends, apical appendage 5-12 $\mu \mathrm{m}$ and basal appendage 5-10 $\mu \mathrm{m}$.

Culture characteristics-Colonies on PDA reaching up to $50 \mathrm{~mm}$ in 10 days, flat with entire edge, forming concentric circles, olivaceous black, sterile. 
Material examined-CHINA, Beijing City, Miyun District, Xinchengzi Town, Potou Village, $40^{\circ} 60^{\prime} 28^{\prime \prime} \mathrm{N}, 117^{\circ} 36^{\prime} 02^{\prime \prime} \mathrm{E}$, alt. $65 \mathrm{~m}$, on leaf spots of Castanea mollissima, 29 October 2017, C.M. Tian \& N. Jiang (BJFC-S1805, holotype; ex-type living cultures, CFCC 54088 = CML1, CML2). Yunnan Province, Zhaotong City, Zhenxiong County, $27^{\circ} 43^{\prime} 28^{\prime \prime} \mathrm{N}$, $105^{\circ} 10^{\prime} 35^{\prime \prime} \mathrm{E}$, alt. $1280 \mathrm{~m}$, on leaf spots of Castanea mollissima, 5 September 2020, N. Jiang (living culture, CFCC 54352 = ZX22A). Hunan Province, Shaoshan City, Yintian Town, $27^{\circ} 52^{\prime} 04^{\prime \prime} \mathrm{N}, 112^{\circ} 35^{\prime} 03^{\prime \prime} \mathrm{E}$, alt. $73 \mathrm{~m}$, on leaf spots of Castanea mollissima, 9 November 2020, C.M. Tian \& N. Jiang (BJFC-S1806, living culture, CFCC $54584=$ SS3).

Notes-Discosia was recorded on leaf spots of Chinese chestnut leaves in the monograph of chestnut diseases [44]. However, the fungus was not identified to the species level. In present study, we collected Discosia samples from Beijing (North China), Hunan and Yunnan (South China), and found it different from any known species $[43,45,46]$. From the phylogram (Figure 9), Discosia brasiliensis was the closest species to D. castaneae, but they could be distinguished by their conidial width (3.5-4.5 $\mu \mathrm{m}$ in D. castaneae vs. $2-3 \mu \mathrm{m}$ in D. brasiliensis) [46].

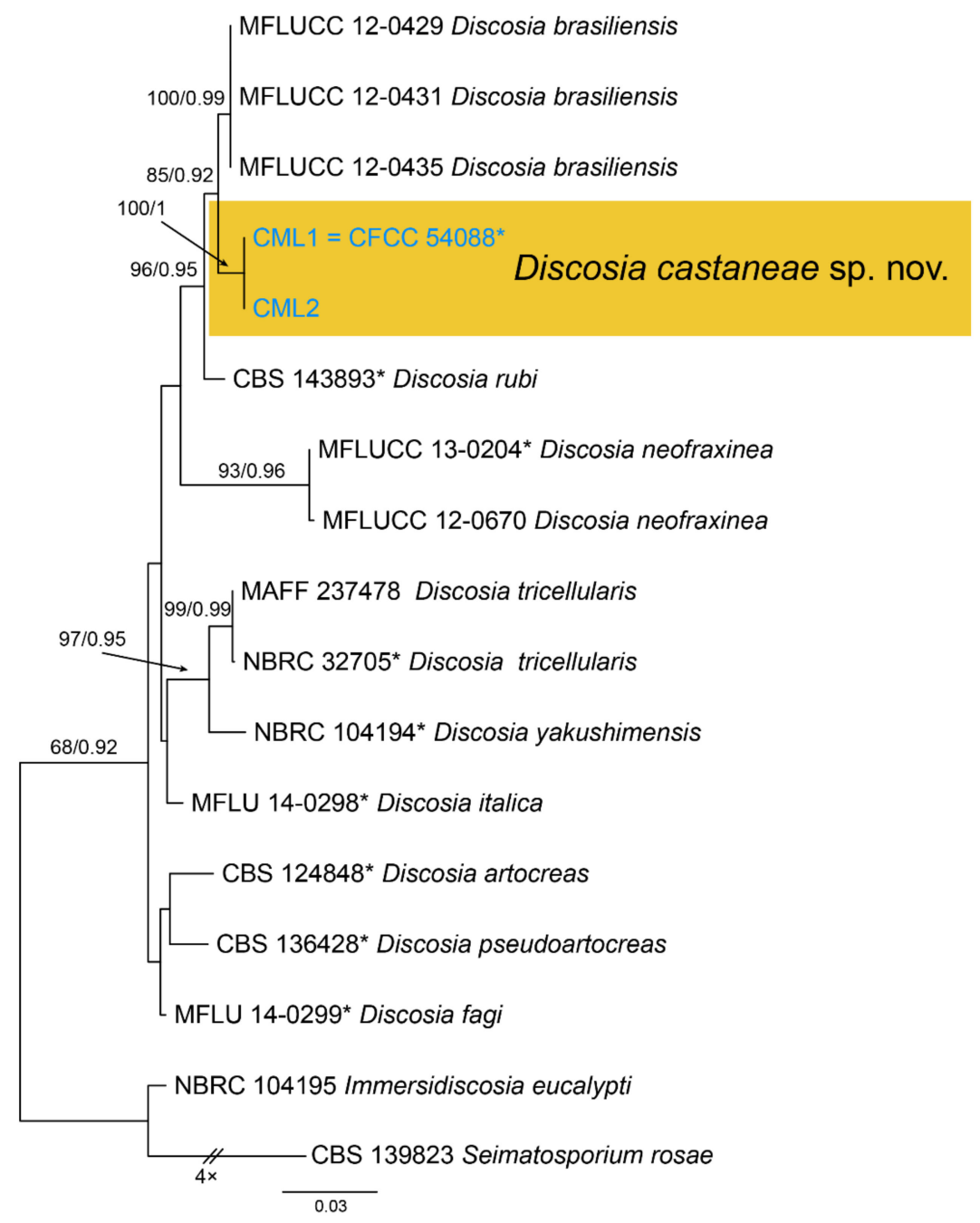

Figure 9. Phylogram generated from RAxML analysis based on combined ITS, LSU and tub2 sequence data of Discosia isolates. The tree was rooted to Immersidiscosia eucalypti (CBS 544.95) and Seimatosporium rosae (CBS 139823). The scale bar indicates 0.03 nucleotide changes per site. Isolates from this study are marked in blue, ex-type strains are marked with *, and the identified species is marked in yellow. 


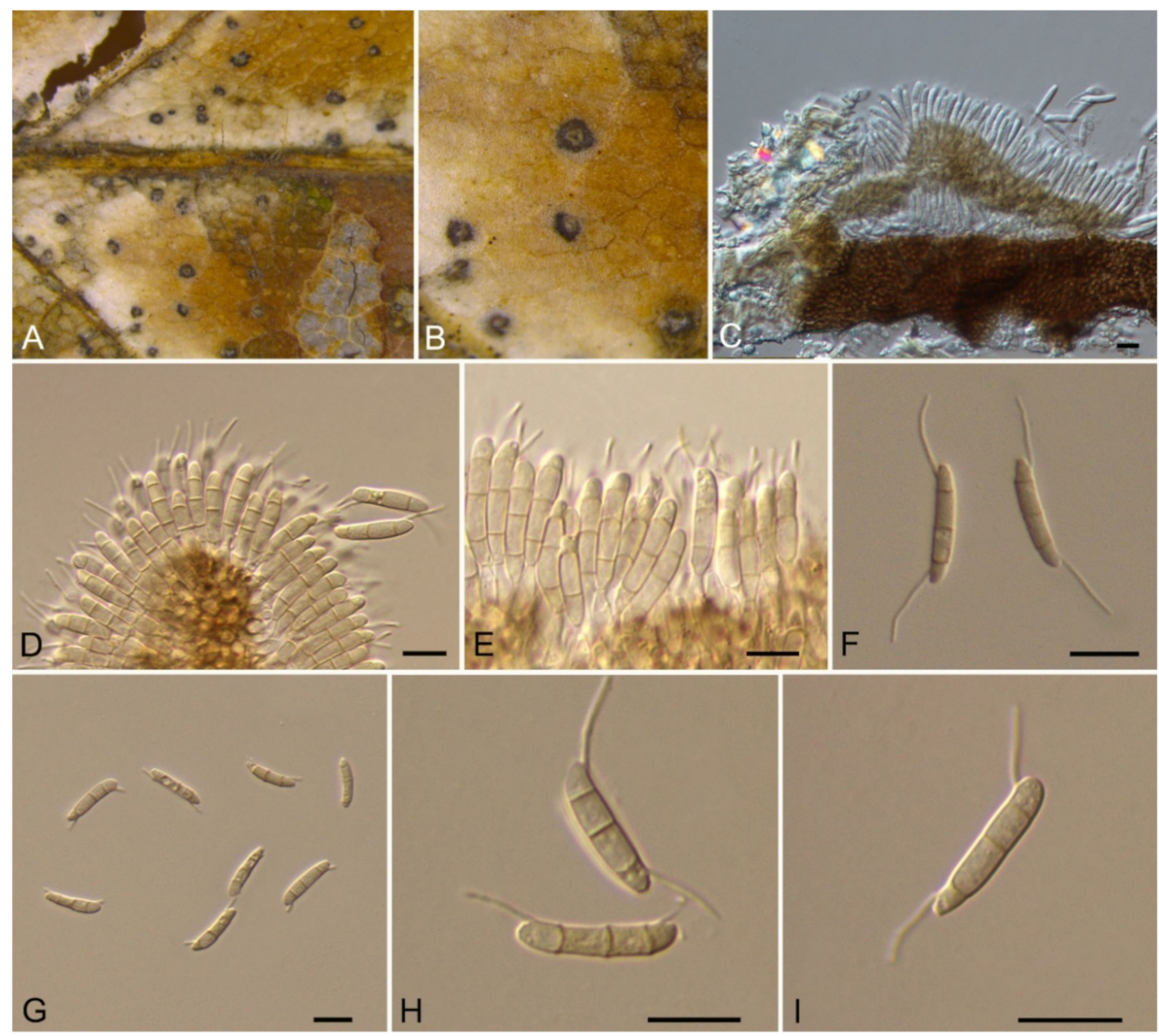

Figure 10. Discosia castaneae (BJFC-S1805). (A,B) Conidiomata on the diseased leaves of Castanea mollissima; (C) Section through the conidioma; (D,E) Conidiogenous cells giving rise to conidia; $(\mathbf{F}-\mathbf{I})$ Conidia. Scale bars: $(\mathbf{C}-\mathbf{I})=10 \mu \mathrm{m}$.

\subsection{Monochaetia (Sacc.) Allesch.}

Monochaetia castaneae C.M. Tian \& N. Jiang, sp. nov. (Figure 12)

MycoBank: MB837793

Etymology—named for the host genus, Castanea.

Holotype-BJFC-S1807

Pathogenic on Castanea mollissima leaves. Sexual morph: Undetermined. Asexual morph: Conidiomata 120-230 $\mu \mathrm{m}$ diam., 20-50 $\mu \mathrm{m}$ high, acervular, conspicuous, scattered or aggregated, rounded, black. Conidiophores cylindrical, hyaline, smooth-walled. Conidiogenous cells 12-20 × 1.5-2.5 $\mu \mathrm{m}$, phialidic, ampulliform, discrete, hyaline, smoothwalled. Conidia (18.8-)20-24(-27.3) $\times(4.7-) 5.4-6.2(-6.6) \mu \mathrm{m}(\bar{x}=22 \times 5.8 \mu \mathrm{m}, n=50)$ $\mathrm{L} / \mathrm{W}=(3.1-) 3.2-4.5(-5.8)(\bar{x}=3.8, n=50)$, fusiform, tapering at both ends, 4 -septate; basal cell 2.5-4.0 $\mu \mathrm{m}$ long, conic, hyaline and smooth-walled; three median cells each 3.5-5.5 $\mu \mathrm{m}$ long, doliiform, light brown, rough-walled; apical cell 3.0-4.5 $\mu \mathrm{m}$ long, conic, hyaline and smooth-walled; apical appendage 17.5-35 $\mu \mathrm{m}$ long, single, tubular, filiform; basal appendage 10-20 $\mu \mathrm{m}$ long, single, central, tubular, filiform.

Culture characteristics-Colonies on PDA reaching up to $40 \mathrm{~mm}$ in 15 days, flat, spreading, with sparse aerial mycelium and smooth, lobate margin, cinnamon, reverse isabelline. Fruiting bodies were observed after 20 days.

Material examined-CHINA, Sichuan Province, Yaan City, Shimian County, $29^{\circ} 13^{\prime} 31^{\prime \prime} \mathrm{N}$, $102^{\circ} 21^{\prime} 27^{\prime \prime}$ E, alt. $978 \mathrm{~m}$, on leaf spots of Castanea mollissima, 10 September 2020, N. Jiang (BJFC-S1807, holotype; ex-type living cultures, CFCC 54354 = SM9-1, SM9-2).

Notes-Monochaetia concentrica and M. kansensis were recorded to inhabit Castanea leaves, but Monochaetia castaneae from present study is narrower than them $(4.7-6.6 \mu \mathrm{m}$ in 
M. castaneae vs. $6.5-8.5 \mu \mathrm{m}$ in M. concentrica vs. 6.0-8.0 $\mu \mathrm{m}$ in M. kansensis) [47]. Monochaetia castaneae is phylogenetically close to $M$. junipericola from twigs of Juniperus communis (Figure 11), but they are distinguished by hosts and conidial sizes (18.8-27.3 × 4.7-6.6 $\mu \mathrm{m}$ in M. castaneae vs. 22-28 × 5.0-7.0 $\mu \mathrm{m}$ in M. junipericola) [48].

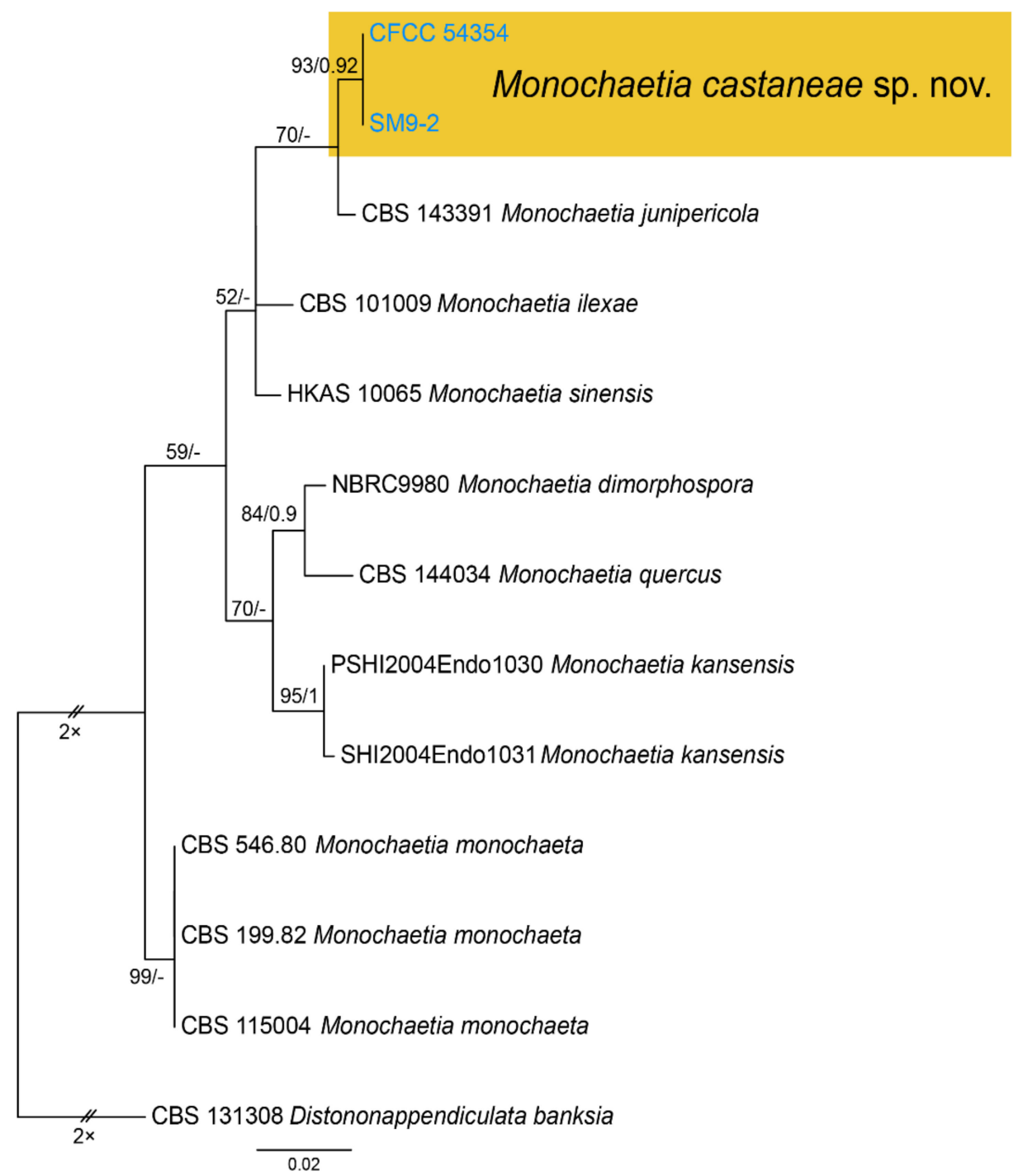

Figure 11. Phylogram generated from RAxML analysis based on combined ITS sequence data of Monochaeta isolates. The tree was rooted to Distononappendiculata banksia (CBS 131308). The scale bar indicates 0.02 nucleotide changes per site. Isolates from this study are highlighted. Isolates from this study are marked in blue, and the identified species is marked in yellow. 

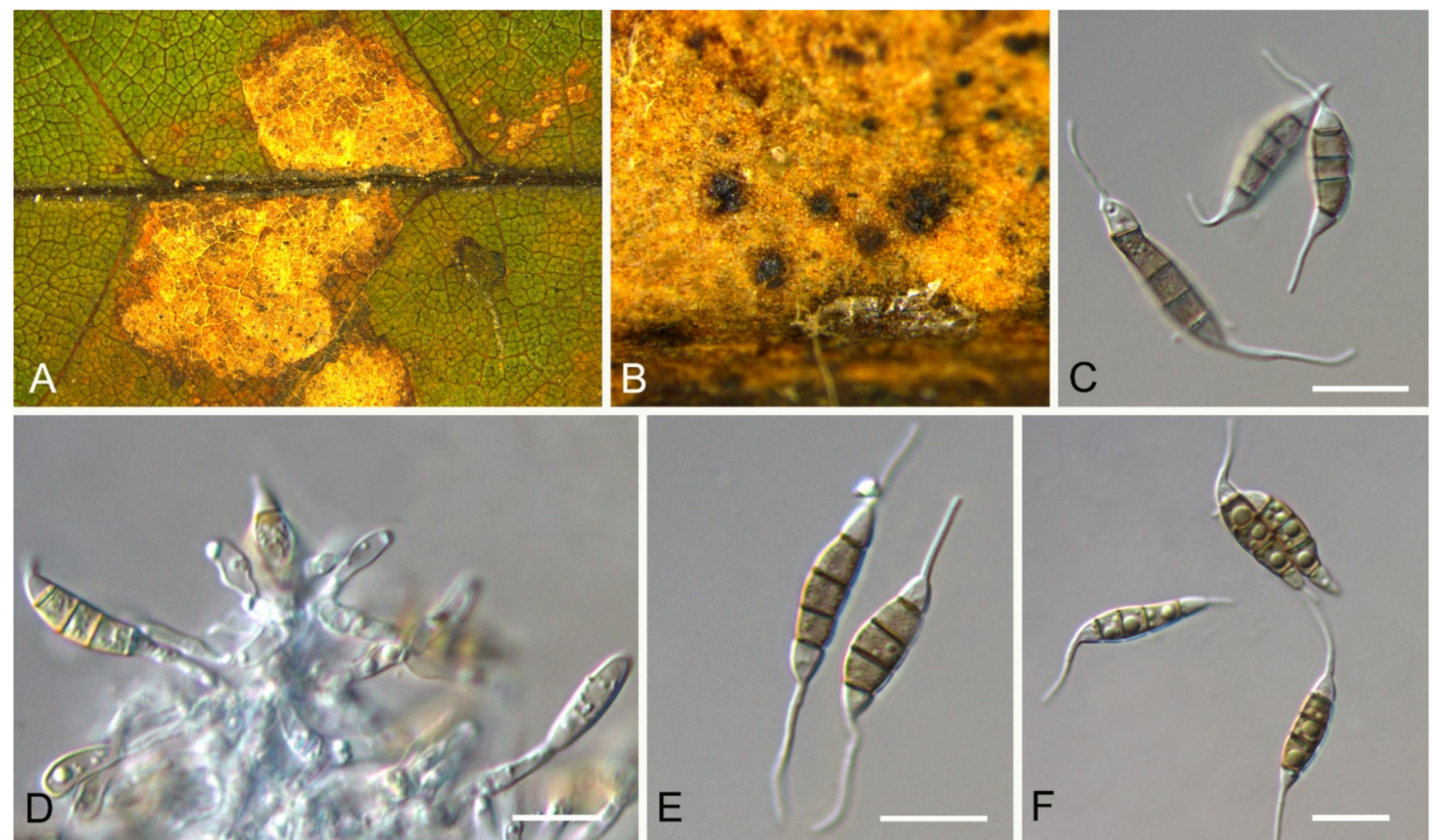

Figure 12. Monochaetia castaneae (BJFC-S1807). (A,B) Conidiomata on the diseased leaves of Castanea mollissima; (C,E,F) Conidia; (D) Conidiogenous cells giving rise to conidia. Scale bars: $(\mathbf{C}-\mathbf{F})=10 \mu \mathrm{m}$.

\subsection{Neopestalotiopsis Maharachch., K.D. Hyde \& Crous}

Neopestalotiopsis asiatica Maharachch., K.D. Hyde \& Crous, Stud. Mycol. 79: 136 (2014) (Figure 14)

Pathogenic on Castanea mollissima leaves. Sexual morph: Undetermined. Asexual morph: Conidiomata 80-200 $\mu \mathrm{m}$ diam., 20-150 $\mu \mathrm{m}$ high, acervular, conspicuous, scattered or aggregated, rounded, black. Conidiophores reduced to conidiogenous cells, smooth, hyaline. Conidiogenous cells 4-10 $\times 1.5-4 \mu \mathrm{m}$, discrete, thin-walled, lageniform, subcylindrical or irregular. Conidia (15.4-)17.6-23.1(-25.5) $\times(4.6-) 5.4-7.8(-8.4) \mu \mathrm{m}(\bar{x}=19.4 \times 6.2 \mu \mathrm{m}$, $n=50), \mathrm{L} / \mathrm{W}=(2.2-) 2.7-3.5(-4)(\bar{x}=3.1, n=50)$, basal cell conic to obconic with a truncate base, hyaline, minutely verruculose and thin-walled, 4-5.5 $\mu \mathrm{m}$ long; three median cells doliiform, versicolourous, second cell from base pale brown to olivaceous, 4.5-6 $\mu \mathrm{m}$ long; third cell honey brown, 5-6.5 $\mu \mathrm{m}$ long; fourth cell brown, 4.5-5.5 $\mu \mathrm{m}$ long; apical cell 3.5-5 $\mu \mathrm{m}$ long, hyaline, subcylindrical, rugose and thin-walled; with 3 (seldom 4) tubular apical appendages, arising from the apical crest, unbranched, filiform, 23-35 $\mu \mathrm{m}$ long; basal appendage present, 3.5-8.5 $\mu \mathrm{m}$ long.

Culture characteristics-Colonies on PDA reaching up to $60 \mathrm{~mm}$ in 10 days, dense aerial mycelium on the surface with undulate edge, white. Fruiting bodies were observed after 20 days.

Material examined-CHINA, Sichuan Province, Yaan City, Shimian County, $29^{\circ} 13^{\prime} 31^{\prime \prime}$ N, $102^{\circ} 21^{\prime} 27^{\prime \prime} \mathrm{E}$, alt. $978 \mathrm{~m}$, on leaf spots of Castanea mollissima, 10 September 2020, N. Jiang (BJFC-S1789, living culture, CFCC 54339 = SM32); ibid. (living cultures, SM7, SM8B, SM11, SM19B).

Notes-Neopestalotiopsis asiatica was described based on the endophytic isolate from unknown trees in China under the name of Pestalotiopsis asiatica [49], but subsequently transferred to the genus Neopestalotiopsis [50]. In the present study, several isolates of $N$. asiatica were obtained from Chinese chestnut diseased leaves (Figure 13). 


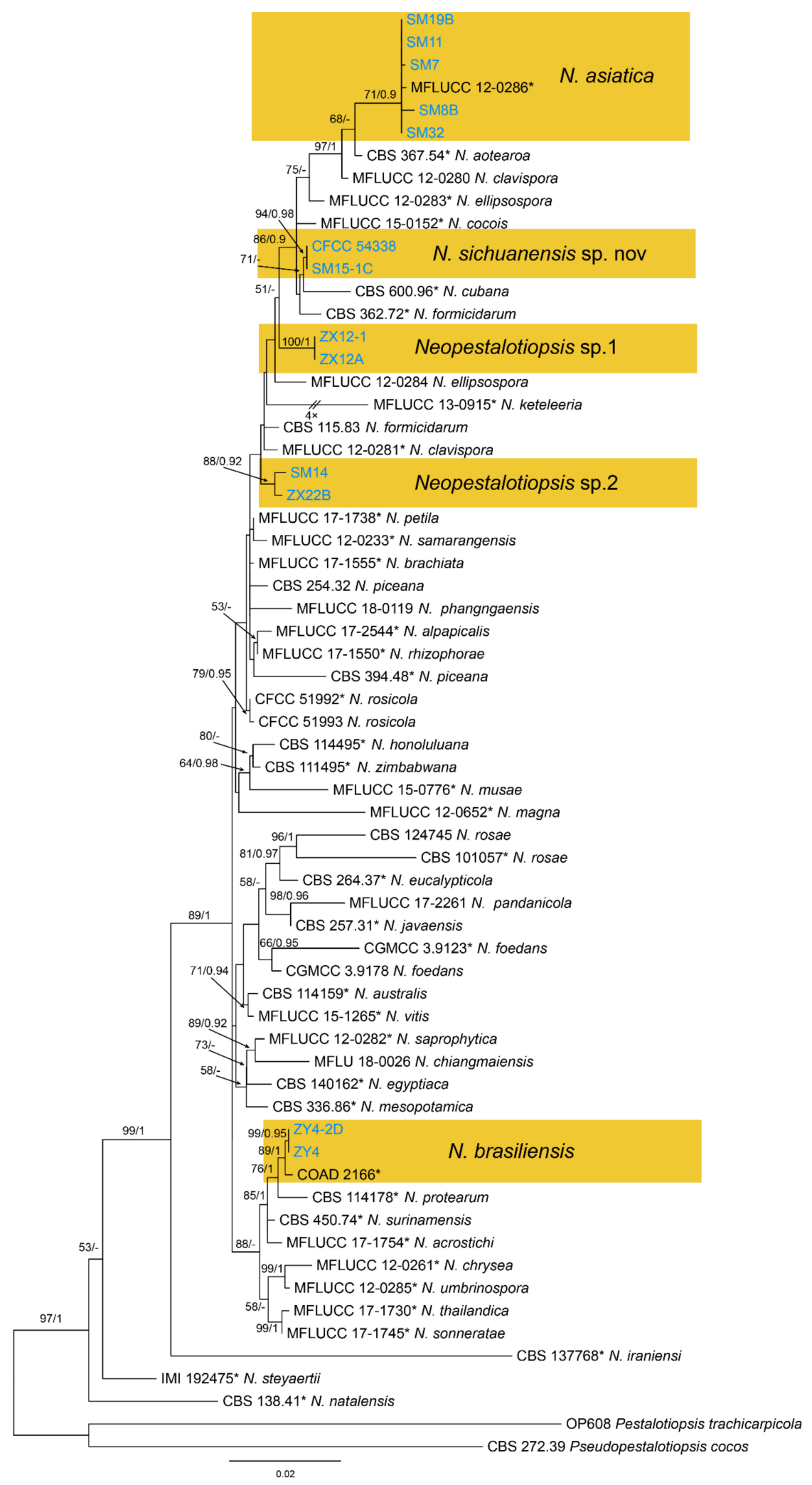

Figure 13. Phylogram generated from RAxML analysis based on combined ITS tef1 and tub2 sequence data of Neopestalotiopsis isolates. The tree was rooted to Pestalotiopsis trachicarpicola (OP608) and Pseudopestalotiopsis cocos (CBS 272.39). The scale bar indicates 0.02 nucleotide changes per site. Isolates from this study are marked in blue, ex-type strains are marked with *, and the identified species are marked in yellow. 

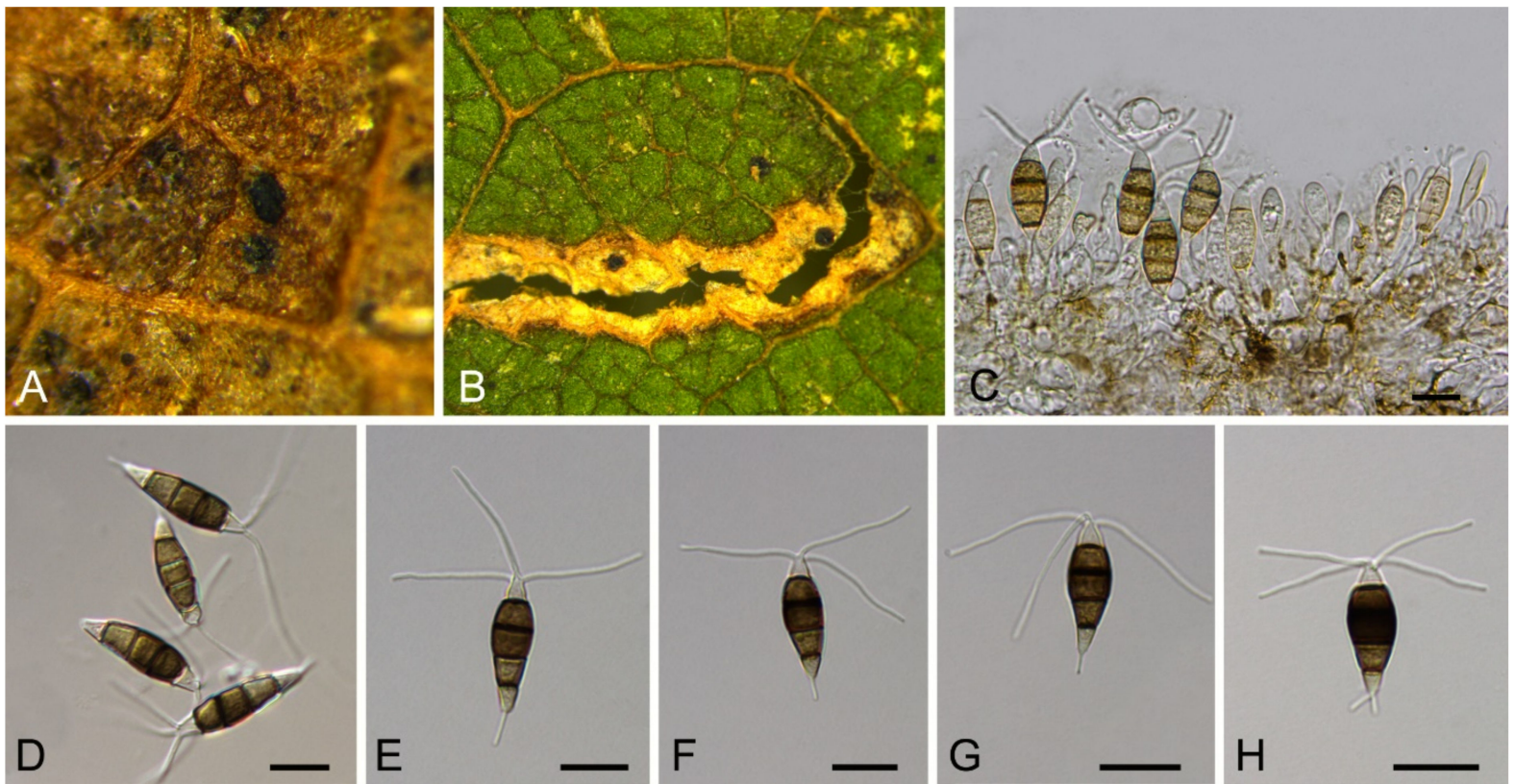

Figure 14. Neopestalotiopsis asiatica (BJFC-S1789). (A,B) Conidiomata on the diseased leaves of Castanea mollissima; (C) Conidiogenous cells giving rise to conidia; $(\mathbf{D}-\mathbf{H})$ Conidia. Scale bars: $(\mathbf{C}-\mathbf{H})=10 \mu \mathrm{m}$.

\subsubsection{Neopestalotiopsis brasiliensis}

Neopestalotiopsis brasiliensis V.P. Abreu, A.W.C. Rosado \& O.L. Pereira, Acta Bot. Brasilica 32(4): 661 (2018) (Figure 15)

Pathogenic on Castanea mollissima leaves. Sexual morph: Undetermined. Asexual morph: Conidiomata 50-150 $\mu \mathrm{m}$ diam., 30-90 $\mu \mathrm{m}$ high, acervular, conspicuous, scattered or aggregated, rounded, black. Conidiophores reduced to conidiogenous cells, smooth, hyaline. Conidiogenous cells 6-15 $\times 1.5-3.5 \mu \mathrm{m}$, discrete, thin-walled, lageniform, subcylindrical or irregular. Conidia (18.5-)19.5-24.1(-26.1) $\times(5-) 5.3-6.4(-6.8) \mu \mathrm{m}$ $(\bar{x}=21.8 \times 5.9 \mu \mathrm{m}, n=50), \mathrm{L} / \mathrm{W}=(2.9-) 3.2-4.3(-4.4)(\bar{x}=3.8, n=50)$, fusoid, ellipsoid to subcylindrical, straight to slightly curved, 4-septate; basal cell conic to obconic with a truncate base, hyaline, minutely verruculose and thin-walled, 3-5.5 $\mu \mathrm{m}$ long; three median cells doliiform, versicolourous, second cell from base pale brown to olivaceous, 4-6.5 $\mu \mathrm{m}$ long; third cell honey brown, 4.5-5.5 $\mu \mathrm{m}$ long; fourth cell brown, $4.5-6 \mu \mathrm{m}$ long; apical cell 3.5-5.5 $\mu \mathrm{m}$ long, hyaline, subcylindrical, rugose and thin-walled; with 2 (seldom 3) tubular apical appendages, arising from the apical crest, unbranched, filiform, 8-20 $\mu \mathrm{m}$ long; basal appendage present, $2-5.5 \mu \mathrm{m}$ long.

Culture characteristics-Colonies on PDA reaching up to $60 \mathrm{~mm}$ in 7 days, dense aerial mycelium on the surface with undulate edge, white. Fruiting bodies were observed after 15 days.

Material examined-CHINA, Guizhou Province, Zunyi City, Goujiang Town, $27^{\circ} 24^{\prime} 49^{\prime \prime} \mathrm{N}$, $106^{\circ} 52^{\prime} 49^{\prime \prime}$ E, alt. $1064 \mathrm{~m}$, on leaf spots of Castanea mollissima, 7 September 2020, N. Jiang (BJFC-S1791, living culture, CFCC 54341 = ZY4); ibid. (living culture, ZY4-2D).

Notes-Neopestalotiopsis brasiliensis was described from rotted fruits of Psidium guajava in Brazil [51]. In present study, strains from diseased chestnut leaves formed a supported clade with the ex-type strain COAD 2166 (Figure 13), and shared similar morphology. Hence, we identified our strains as $N$. brasiliensis, which represented a new host and geographical record. 

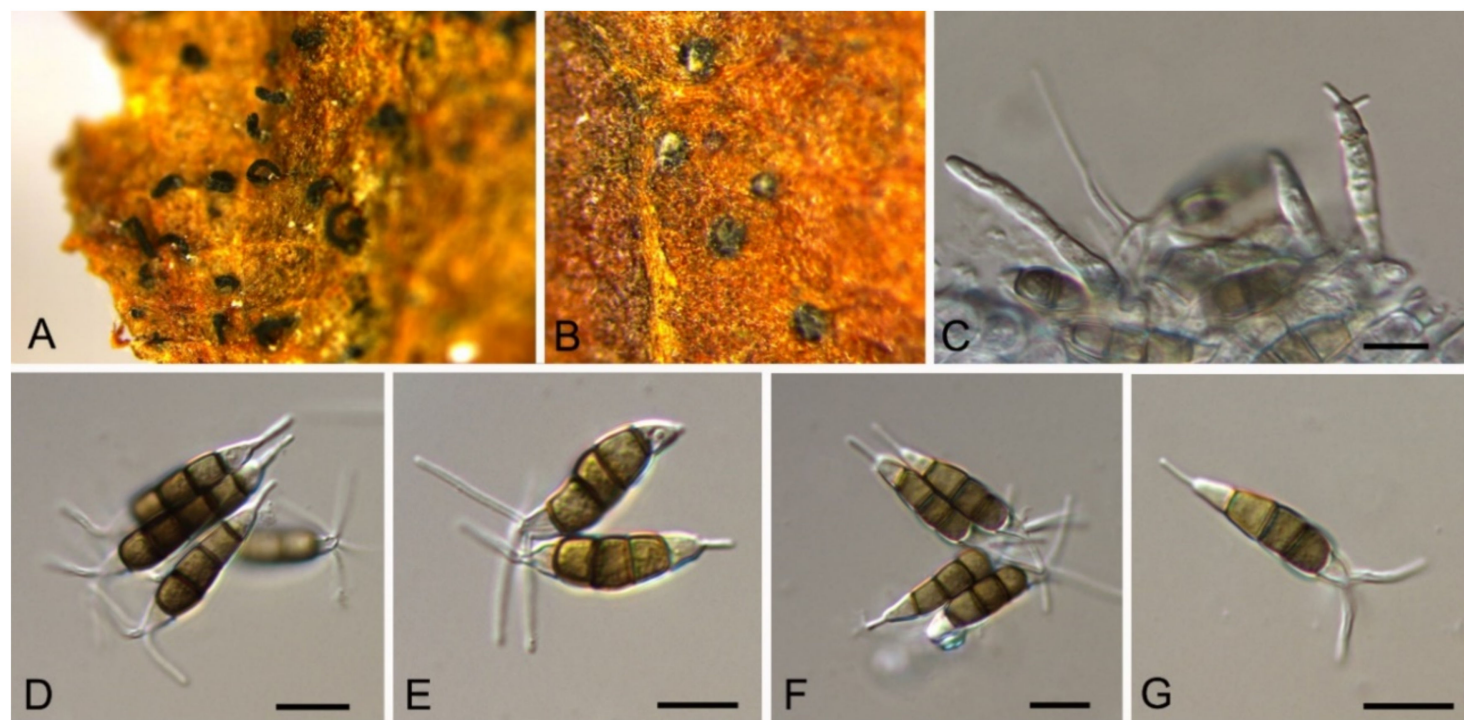

Figure 15. Neopestalotiopsis brasiliensis (BJFC-S1791). (A,B) Conidiomata on the diseased leaves of Castanea mollissima; (C) Conidiogenous cells giving rise to conidia; (D-G) Conidia. Scale bars: $(\mathbf{C}-\mathbf{G})=10 \mu \mathrm{m}$.

\subsubsection{Neopestalotiopsis sichuanensis}

C.M. Tian \& N. Jiang, sp. nov. (Figure 16)

MycoBank: MB 837792

Etymology—named for the location of the type specimen.

Holotype-BJFC-S1788

Pathogenic on Castanea mollissima leaves. Sexual morph: Undetermined. Asexual morph: Conidiomata 100-250 $\mu \mathrm{m}$ diam., 50-150 $\mu \mathrm{m}$ high, acervular, conspicuous, scattered or aggregated, rounded, black. Conidiophores reduced to conidiogenous cells, smooth, hyaline. Conidiogenous cells 7-20 $\times 2-6 \mu \mathrm{m}$, discrete, thin-walled, lageniform, subcylindrical or irregular. Conidia (23.2-)24.3-30.4(-32.8) $\times(5.7-) 6.3-7.1(-7.5) \mu \mathrm{m}(\bar{x}=27.3 \times 6.7 \mu \mathrm{m}$, $n=50), \mathrm{L} / \mathrm{W}=(3.4-) 3.5-4.6(-5.1)(\bar{x}=4.1, n=50)$, fusoid, ellipsoid to subcylindrical, straight to slightly curved, 4 -septate; basal cell conic to obconic with a truncate base, hyaline, minutely verruculose and thin-walled, 3.5-5 $\mu \mathrm{m}$ long; three median cells doliiform, versicolourous, second cell from base pale brown to olivaceous, 3.5-6 $\mu \mathrm{m}$ long; third cell honey brown, 4.5-6.5 $\mu \mathrm{m}$ long; fourth cell brown, 4.5-6 $\mu \mathrm{m}$ long; apical cell 3.5-6 $\mu \mathrm{m}$ long, hyaline, subcylindrical, rugose and thin-walled; with 2 or 3 tubular apical appendages, arising from the apical crest, unbranched, filiform, $8-15 \mu \mathrm{m}$ long; basal appendage present, $1.5-4 \mu \mathrm{m}$ long.

Culture characteristics-Colonies on PDA reaching up to $60 \mathrm{~mm}$ in 7 days, dense aerial mycelium on the surface with undulate edge, white. Fruiting bodies were observed after 15 days.

Material examined-CHINA, Sichuan Province, Yaan City, Shimian County, $29^{\circ} 13^{\prime} 31^{\prime \prime} \mathrm{N}$, $102^{\circ} 21^{\prime} 27^{\prime \prime}$ E, alt. $978 \mathrm{~m}$, on leaf spots of Castanea mollissima, 10 September 2020, N. Jiang (BJFC-S1788, holotype; ex-type living culture, CFCC 54338 = SM15-1); ibid. (living culture, SM15-1C).

Notes-Neopestalotiopsis sichuanensis was phylogenetically close to N. cubana (Figure 13) but differed in conidial width (5.7-7.5 $\mu \mathrm{m}$ in N. sichuanensis vs. 7.5-10 $\mu \mathrm{m}$ in N. cubana) [50]. 

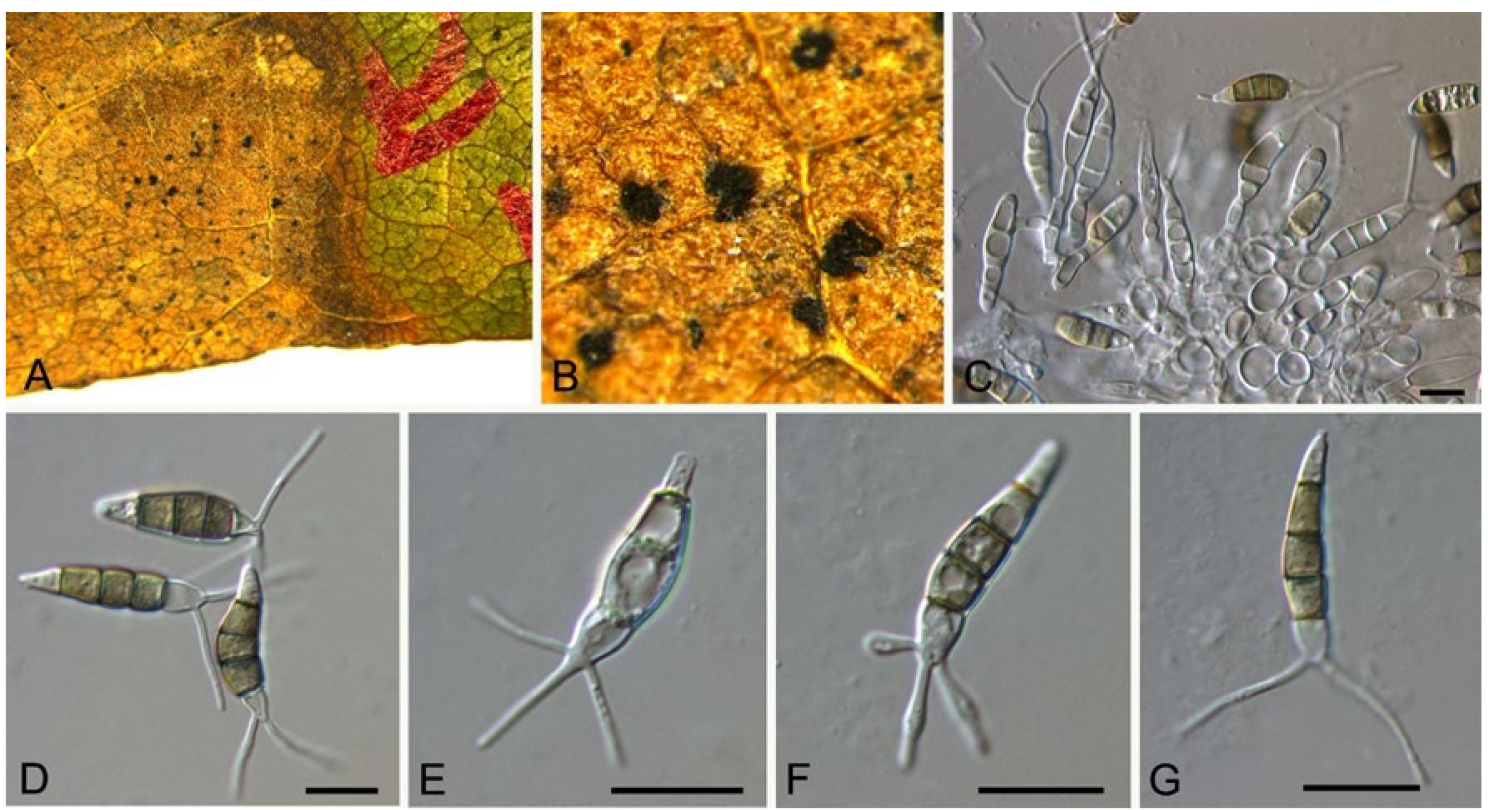

Figure 16. Neopestalotiopsis sichuanensis (BJFC-S1788). (A,B) Conidiomata on the diseased leaves of Castanea mollissima; (C) Conidiogenous cells giving rise to conidia; $(\mathbf{D}-\mathbf{G})$ Conidia. Scale bars: $(\mathbf{C}-\mathbf{G})=10 \mu \mathrm{m}$.

\subsubsection{Neopestalotiopsis sp.1}

Pathogenic on Castanea mollissima leaves. Sexual morph: Undetermined. Asexual morph: Conidiomata 80-150 $\mu \mathrm{m}$ diam., 30-60 $\mu \mathrm{m}$ high, acervular, conspicuous, scattered or aggregated, rounded, black. Conidiophores reduced to conidiogenous cells, smooth, hyaline. Conidiogenous cells 5.5-15.5 $\times 3-7 \mu \mathrm{m}$, discrete, thin-walled, lageniform, subcylindrical or irregular. Conidia (19.1-)19.9-23.2(-24.7) $\times(5.4-) 5.8-7.6(-8.6) \mu \mathrm{m}$ $(\bar{x}=21.6 \times 6.7 \mu \mathrm{m}, n=50), \mathrm{L} / \mathrm{W}=(2.9-) 3.0-3.5(-3.7)(\bar{x}=3.2, n=50)$, fusoid, ellipsoid to subcylindrical, straight to slightly curved, 4 -septate; basal cell conic to obconic with a truncate base, hyaline, minutely verruculose and thin-walled, 3-4.5 $\mu \mathrm{m}$ long; three median cells doliiform, versicolourous, second cell from base pale brown to olivaceous, 3-5 $\mu \mathrm{m}$ long; third cell honey brown, 4.5-6 $\mu \mathrm{m}$ long; fourth cell brown, 4-6 $\mu \mathrm{m}$ long; apical cell 3.5-5 $\mu \mathrm{m}$ long, hyaline, subcylindrical, rugose and thin-walled; with 2 or 3 tubular apical appendages, arising from the apical crest, unbranched, filiform, 7.5-14 $\mu \mathrm{m}$ long; basal appendage present, 3-6.5 $\mu \mathrm{m}$ long (Figure 17).

Culture characteristics-Colonies on PDA reaching up to $60 \mathrm{~mm}$ in 7 days, dense aerial mycelium on the surface with undulate edge, white. Fruiting bodies were observed after 15 days.

Material examined-CHINA, Yunnan Province, Zhaotong City, Zhenxiong County, $27^{\circ} 43^{\prime} 28^{\prime \prime} \mathrm{N}, 105^{\circ} 10^{\prime} 35^{\prime \prime} \mathrm{E}$, alt. $1280 \mathrm{~m}$, on leaf spots of Castanea mollissima, 5 September 2020, N. Jiang (BJFC-S1787, living culture, CFCC 54337 = ZX12A); ibid. (living culture, ZX12-1).

Notes-Although phylogenetically distinct, these two isolates were not proposed as a new species for lack of distinguished characters from close clades (Figure 13). 


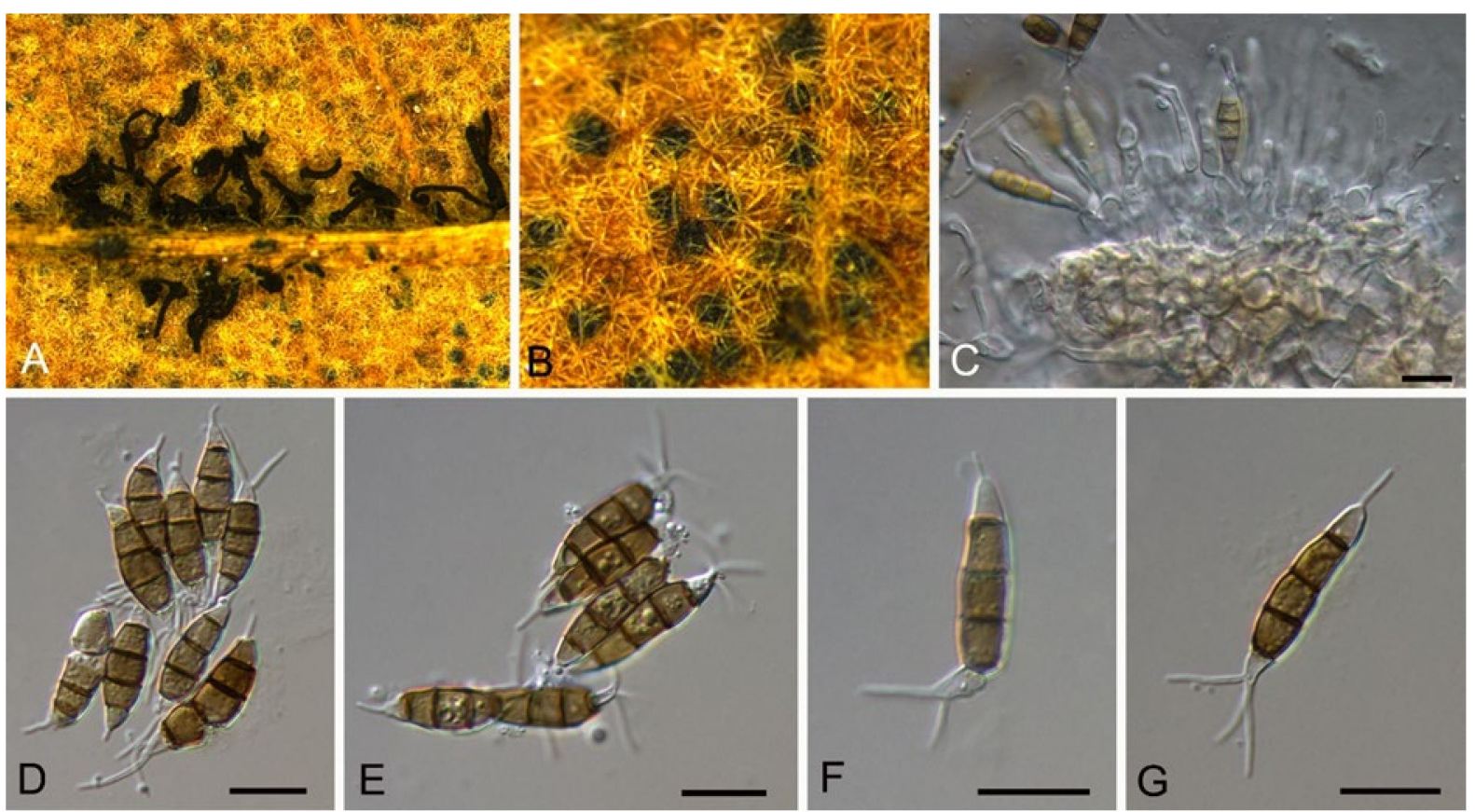

Figure 17. Neopestalotiopsis sp.1 (BJFC-S1787). (A,B) Conidiomata on the diseased leaves of Castanea mollissima; (C) Conidiogenous cells giving rise to conidia; (D-G) Conidia. Scale bars: $(\mathbf{C}-\mathbf{G})=10 \mu \mathrm{m}$.

\subsubsection{Neopestalotiopsis sp.2}

Pathogenic on Castanea mollissima leaves. Sexual morph: Undetermined. Asexual morph: Conidiomata 75-175 $\mu \mathrm{m}$ diam., 30-75 $\mu \mathrm{m}$ high, acervular, conspicuous, scattered or aggregated, rounded, black. Conidiophores reduced to conidiogenous cells, smooth, hyaline. Conidiogenous cells 3.5-8 $\times 2.5-5.5 \mu \mathrm{m}$, discrete, thin-walled, lageniform, subcylindrical or irregular. Conidia (21.4-)22-25.2(-26.2) $\times(5.1-) 6.2-7.7(-8.7) \mu \mathrm{m}$ $(\bar{x}=23.6 \times 7 \mu \mathrm{m}, n=50), \mathrm{L} / \mathrm{W}=(2.9-) 3-3.9(-4.4)(\bar{x}=3.4, n=50)$, fusoid, ellipsoid to subcylindrical, straight to slightly curved, 4 -septate; basal cell conic to obconic with a truncate base, hyaline, minutely verruculose and thin-walled, 3-5 $\mu \mathrm{m}$ long; three median cells doliiform, versicolourous, second cell from base pale brown to olivaceous, 4.5-6.5 $\mu \mathrm{m}$ long; third cell honey brown, 4.5-6 $\mu \mathrm{m}$ long; fourth cell brown, 4-6 $\mu \mathrm{m}$ long; apical cell 3.5-5 $\mu \mathrm{m}$ long, hyaline, subcylindrical, rugose and thin-walled; with 2 (seldom 3) tubular apical appendages, arising from the apical crest, unbranched, filiform, 10-25 $\mu \mathrm{m}$ long; basal appendage present, 1.5-5 $\mu \mathrm{m}$ long (Figure 18).

Culture characteristics-Colonies on PDA reaching up to $60 \mathrm{~mm}$ in 7 days, dense aerial mycelium on the surface with undulate edge, white. Fruiting bodies were observed after 15 days.

Material examined-CHINA, Sichuan Province, Yaan City, Shimian County, $29^{\circ} 13^{\prime} 31^{\prime \prime} \mathrm{N}$, $102^{\circ} 21^{\prime} 27^{\prime \prime}$ E, alt. $978 \mathrm{~m}$, on leaf spots of Castanea mollissima, 10 September 2020, N. Jiang (BJFC-S1790, living culture, CFCC 54340 = SM14); Yunnan Province, Zhaotong City, Zhenxiong County, $27^{\circ} 43^{\prime} 28^{\prime \prime} \mathrm{N}, 105^{\circ} 10^{\prime} 35^{\prime \prime} \mathrm{E}$, alt. $1280 \mathrm{~m}$, on leaf spots of Castanea mollissima, 5 September 2020, N. Jiang (living culture, ZX22B).

Notes-Although phylogenetically distinct, these two isolates were not proposed as a new species for lack of distinguished characters from close clades (Figure 13). 

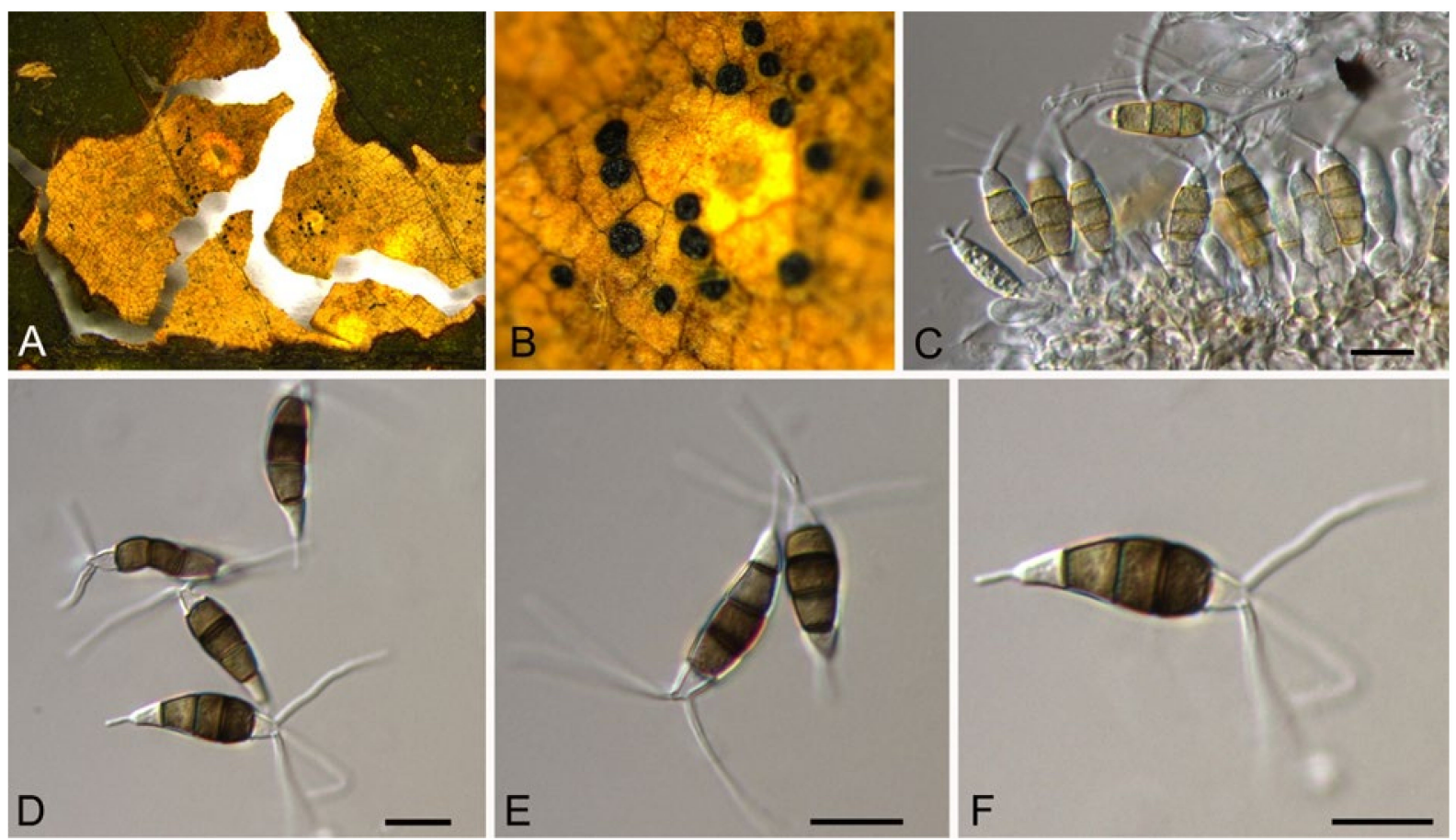

Figure 18. Neopestalotiopsis sp.2 (BJFC-S1790). (A,B) Conidiomata on the diseased leaves of Castanea mollissima; (C) Conidiogenous cells giving rise to conidia; $(\mathbf{D}-\mathbf{F})$ Conidia. Scale bars: $(\mathbf{C}-\mathbf{F})=10 \mu \mathrm{m}$.

\subsection{Pestalotiopsis Steyaert}

Pestalotiopsis kenyana Maharachch., K.D. Hyde \& Crous, Stud. Mycol. 79: 166 (2014) (Figure 19)

Pathogenic on Castanea henryi and C. mollissima leaves. Sexual morph: Undetermined. Asexual morph: Conidiomata 50-250 $\mu \mathrm{m}$ diam., 30-150 $\mu \mathrm{m}$ high, acervular, conspicuous, scattered or aggregated, rounded, black. Conidiophores reduced to conidiogenous cells, smooth, hyaline. Conidiogenous cells 5-19 $\times 2.5-6.5 \mu \mathrm{m}$, discrete, thin-walled, lageniform, subcylindrical or irregular. Conidia (20.4-)21.8-26.2(-28) $\times(6.1-) 6.3-7.4(-8) \mu \mathrm{m}$ $(\bar{x}=23.8 \times 6.9 \mu \mathrm{m}, n=50), \mathrm{L} / \mathrm{W}=(3-) 3.1-3.9(-4.2)(\bar{x}=3.5, n=50)$, fusoid, ellipsoid to subcylindrical, straight to slightly curved, 4 -septate; basal cell conic to obconic with a truncate base, hyaline, minutely verruculose and thin-walled, 3-5 $\mu \mathrm{m}$ long; three median cells doliiform, concolourous, brown, second cell 3-5.5 $\mu \mathrm{m}$ long; third cell 4.5-6.5 $\mu \mathrm{m}$ long; fourth cell 4.5-6 $\mu \mathrm{m}$ long; apical cell 3.5-5.5 $\mu \mathrm{m}$ long, hyaline, subcylindrical, rugose and thin-walled; with 3 tubular apical appendages, arising from the apical crest, unbranched, filiform, 3.5-15 $\mu \mathrm{m}$ long; basal appendage present, 1.5-3.5 $\mu \mathrm{m}$ long.

Culture characteristics-Colonies on PDA reaching up to $60 \mathrm{~mm}$ in 7 days, dense aerial mycelium on the surface with undulate edge, white. Fruiting bodies were observed after 15 days.

Material examined-CHINA, Yunnan Province, Zhaotong City, Zhenxiong County, $27^{\circ} 43^{\prime} 28^{\prime \prime} \mathrm{N}, 105^{\circ} 10^{\prime} 35^{\prime \prime} \mathrm{E}$, alt. $1280 \mathrm{~m}$, on leaf spots of Castanea mollissima, 5 September 2020, N. Jiang (BJFC-S1784, living culture, CFCC 54336 = ZX11); ibid. (living culture, ZX3, ZX7, ZX9, ZX18A); Guizhou Province, Zunyi City, Goujiang Town, $27^{\circ} 24^{\prime} 49^{\prime \prime}$ N, $106^{\circ} 52^{\prime} 49^{\prime \prime}$ E, alt. $1064 \mathrm{~m}$, on leaf spots of Castanea mollissima, 7 September 2020, N. Jiang (BJFC-S1786, living culture, ZY6-2A); ibid. (living culture, ZY7); Sichuan Province, Yaan City, Shimian County, $29^{\circ} 13^{\prime} 31^{\prime \prime} \mathrm{N}, 102^{\circ} 21^{\prime} 27^{\prime \prime} \mathrm{E}$, alt. $978 \mathrm{~m}$, on leaf spots of Castanea mollissima, 10 September 2020, N. Jiang (BJFC-S1785, living culture, SM18); Hunan Province, Changsha City, Changsha County, Jinjing Town, $28^{\circ} 58^{\prime} 52^{\prime \prime}$ N, $113^{\circ} 34^{\prime} 38^{\prime \prime}$ E, alt. $63 \mathrm{~m}$, on leaf spots of Castanea henryi, 10 November 2020, C.M. Tian \& N. Jiang (BJFC-S1817; living culture, JJ 2A); ibid. (living cultures, JJ5, JJ10, JJ13, JJ15, JJ17, JJ18, JJ26). 
Notes-Pestalotiopsis kenyana was proposed from Coffea sp. in Kenya [50]. Strains collected from Castanea mollissima in present study formed a supported clade with Pestalotiopsis kenyana (Figure A7), and shared similar morphology. Hence, we identified our strains as P. kenyana, which represented a new host record.
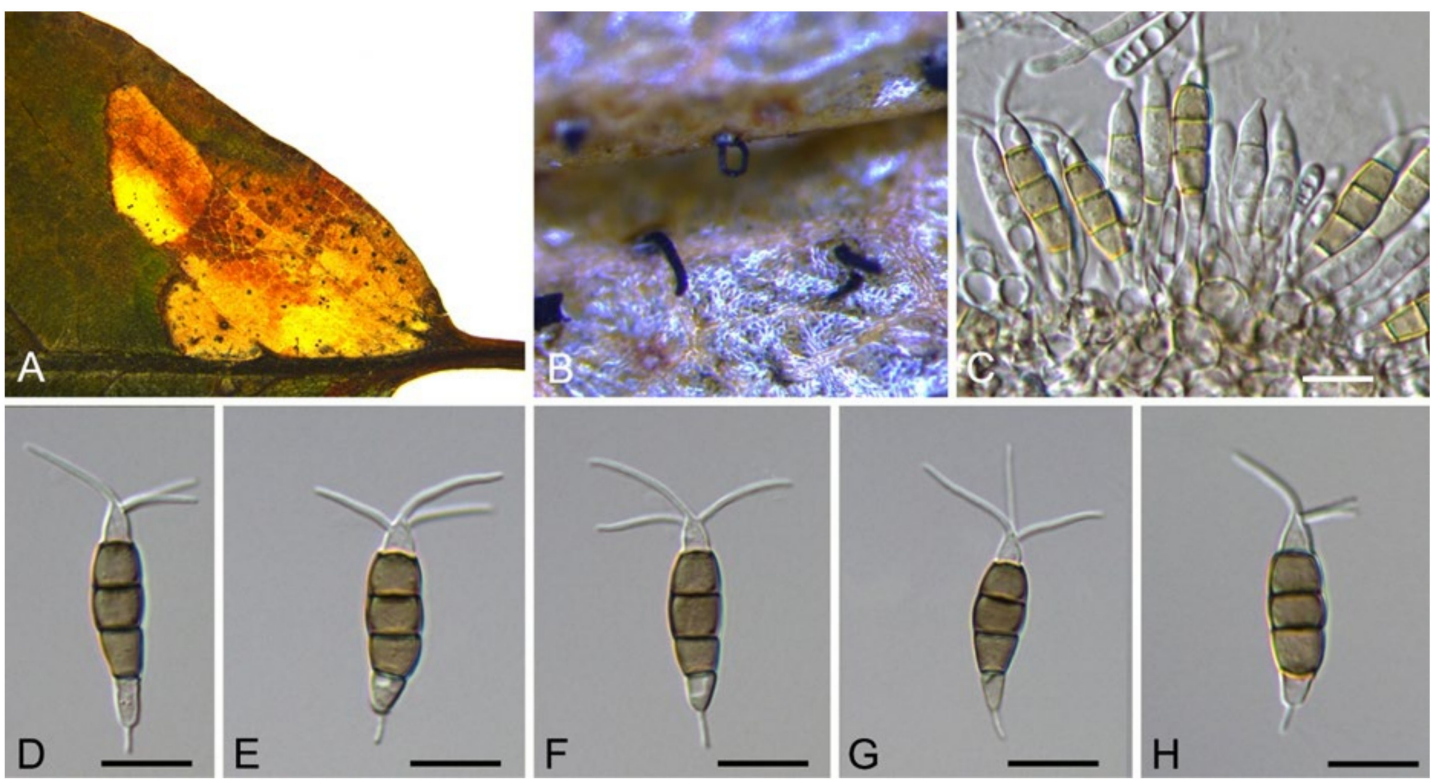

Figure 19. Pestalotiopsis kenyana (BJFC-S1784). (A,B) Conidiomata on the diseased leaves of Castanea mollissima; (C) Conidiogenous cells giving rise to conidia; $(\mathbf{D}-\mathbf{H})$ Conidia. Scale bars: $(\mathbf{C}-\mathbf{H})=10 \mu \mathrm{m}$.

\subsection{Robillarda Sacc.}

Robillarda sessilis (Sacc.) Sacc., Michelia 2(no. 6): 8 (1880) (Figure 20)

Pathogenic on Castanea mollissima leaves. Sexual morph: Undetermined. Asexual morph: Conidiomata 100-200 $\mu \mathrm{m}$ diam., 20-60 $\mu \mathrm{m}$ high, acervular, conspicuous, scattered or aggregated, rounded, black. Conidiophores reduced to conidiogenous cells, smooth, hyaline. Conidiogenous cells $2.5-6 \times 1.5-3 \mu \mathrm{m}$, discrete, thin-walled, guttulate or not, lageniform, ampulliform or irregular. Conidia composed of a 1-septate conidium body and a septate apical cell modified into a branched appendage. Conidium body (10.7-)11.213.1(-13.5) $\times(2.9-) 3.1-3.8(-3.9) \mu \mathrm{m}(\bar{x}=12.2 \times 3.4 \mu \mathrm{m}, n=50), \mathrm{L} / \mathrm{W}=(2.9-) 3.1-4.1(-4.5)$ $(\bar{x}=3.6, n=50)$, cylindrical, straight, 1-septate, smooth, hyaline to pale brown, guttulate, slightly constricted at the median septum; apical cell cylindrical for 4.0-5.0 $\mu \mathrm{m}$ long, then dividing into $2-4$ (mostly 3 ) divergent branches; apical appendages unbranched, attenuated, 15-28 $\mu \mathrm{m}$ long; basal appendages absent.

Culture characteristics-Colonies on PDA reaching up to $60 \mathrm{~mm}$ in 15 days, flat with entire edge, white, aerial mycelia villiform. Fruiting bodies were observed after 20 days.

Material examined-CHINA, Yunnan Province, Zhaotong City, Zhenxiong County, $27^{\circ} 43^{\prime} 28^{\prime \prime} \mathrm{N}, 105^{\circ} 10^{\prime} 35^{\prime \prime} \mathrm{E}$, alt. $1280 \mathrm{~m}$, on leaf spots of Castanea mollissima, 5 September 2020, N. Jiang (BJFC-S1804, living culture, CFCC 54353 = ZX5); ibid. (living culture, ZX5-1); Guizhou Province, Zunyi City, Goujiang Town, $27^{\circ} 24^{\prime} 49^{\prime \prime}$ N, $106^{\circ} 52^{\prime} 49^{\prime \prime}$ E, alt. $1064 \mathrm{~m}$, on leaf spots of Castanea mollissima, 7 September 2020, N. Jiang (living culture, ZY5-1).

Notes-Robillarda sessilis was documented from quite variable hosts, such as Bischofia, Cocos, Ficus, Fragaria, Fumana, Ludwigia, Magnolia, Paeonia, Quercus, Randia, Rosa, Rubus, and Vitis [52]. Strains from present study clustered with the ex-epitype strain (CBS 114312) of Robillarda sessilis (Figure A8). This is the first report of this fungus on the host Castanea mollissima, and in China as a country. 

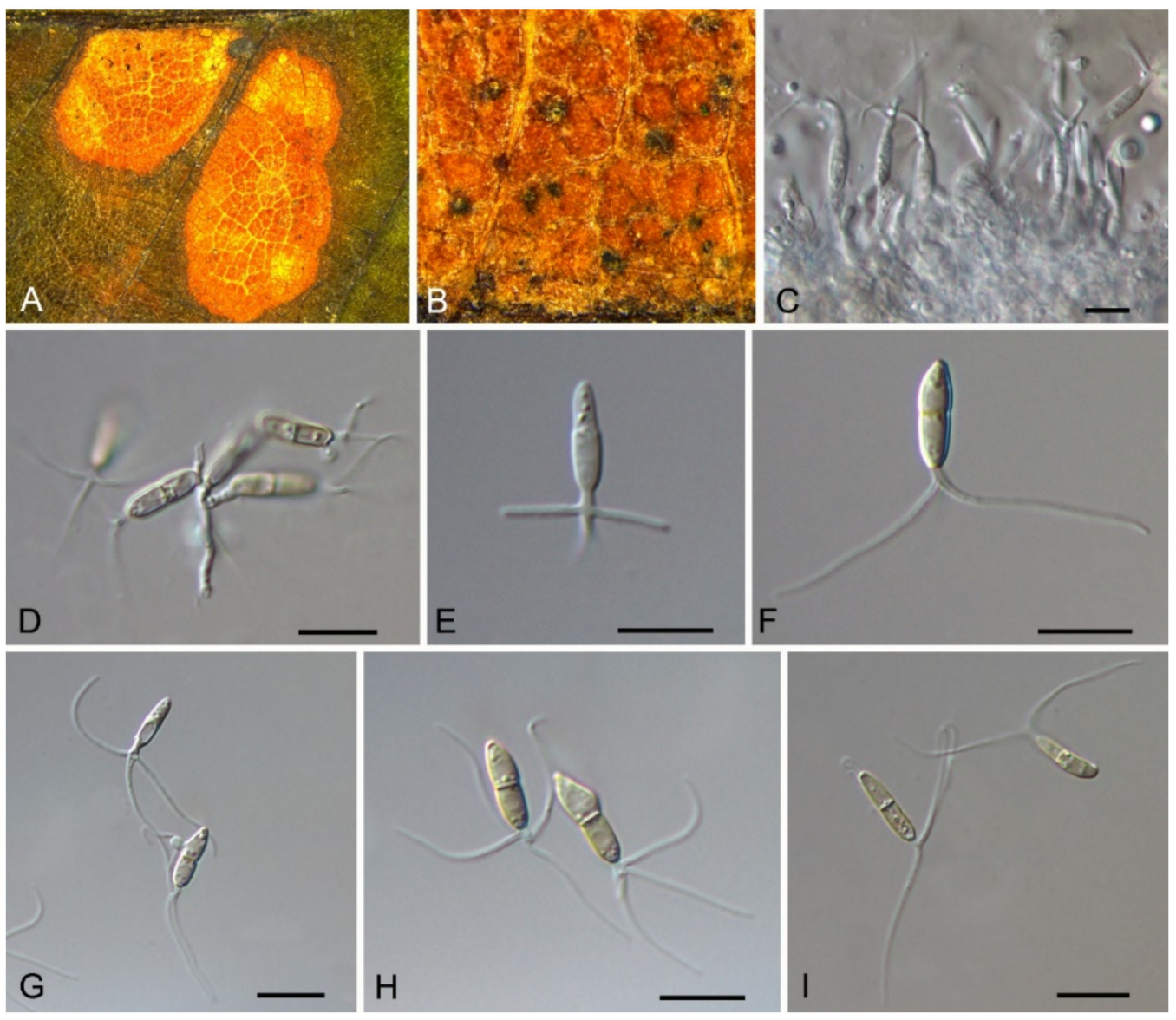

Figure 20. Robillarda sessilis (BJFC-S1804). (A,B) Conidiomata on the diseased leaves of Castanea mollissima; (C,D) Conidiogenous cells giving rise to conidia; $(\mathbf{E}-\mathbf{I})$ Conidia. Scale bars: $(\mathbf{C}-\mathbf{I})=10 \mu \mathrm{m}$.

\subsection{Diaporthe Nitschke}

Diaporthe lithocarpi Y.H. Gao \& L. Cai, Fungal Biology 119(5): 306 (2015) (Figure 21)

Pathogenic on Castanea henryi leaves. Sexual morph: Undetermined. Asexual morph: Conidiomata 120-3000 $\mu \mathrm{m}$ diam., pycnidial, aggregated, globose to subglobose, black. Conidiophores reduced to conidiogenous cells. Conidiogenous cells 2.5-12.5 $\times 1.5-3 \mu \mathrm{m}$, cylindrical, hyaline, phiailidic, unbranched, straight. Conidia (7.6-)7.9-9.1(-9.8) $\times(2.5-) 2.6-$ $3(-3.1) \mu \mathrm{m}(\bar{x}=8.5 \times 2.8 \mu \mathrm{m}, n=50), \mathrm{L} / \mathrm{W}=(2.4-) 2.7-3.4(-3.7)(\bar{x}=3.1, n=50)$, aseptate, hyaline, ellipsoidal, biguttulate, mostly with one end obtuse and the other acute.

Culture characteristics-Colonies on PDA reaching up to $60 \mathrm{~mm}$ in 7 days, flat, initially white mycelium, gradually becoming pale brownish, with cottony aerial mycelium and fringed margin; reverse pale yellowish.

Material examined-CHINA, Hunan Province, Changsha City, Changsha County, Jinjing Town, $28^{\circ} 58^{\prime} 52^{\prime \prime} \mathrm{N}, 113^{\circ} 34^{\prime} 38^{\prime \prime} \mathrm{E}$, alt. $63 \mathrm{~m}$, on leaf spots of Castanea henryi, 10 November 2020, C.M. Tian \& N. Jiang (BJFC-S1809; living culture, CFCC $54573=$ JJ3); ibid. (living cultures, JJ3-2, JJ26B).

Notes-Diaporthe lithocarpi was reported to cause leaf spots on Lithocarpus glabra, Loropetalum chinensis, Smilax china, S. glabra and Ternstroemia gymnanthera in Zhejiang Province of China [53]. The present study adds a new Castanea henryi host for the fungus based on the phylogenetic inference of ITS, cal, his, tef1 and tub2 sequence data (Figure A9), and exactly matched morphology. 

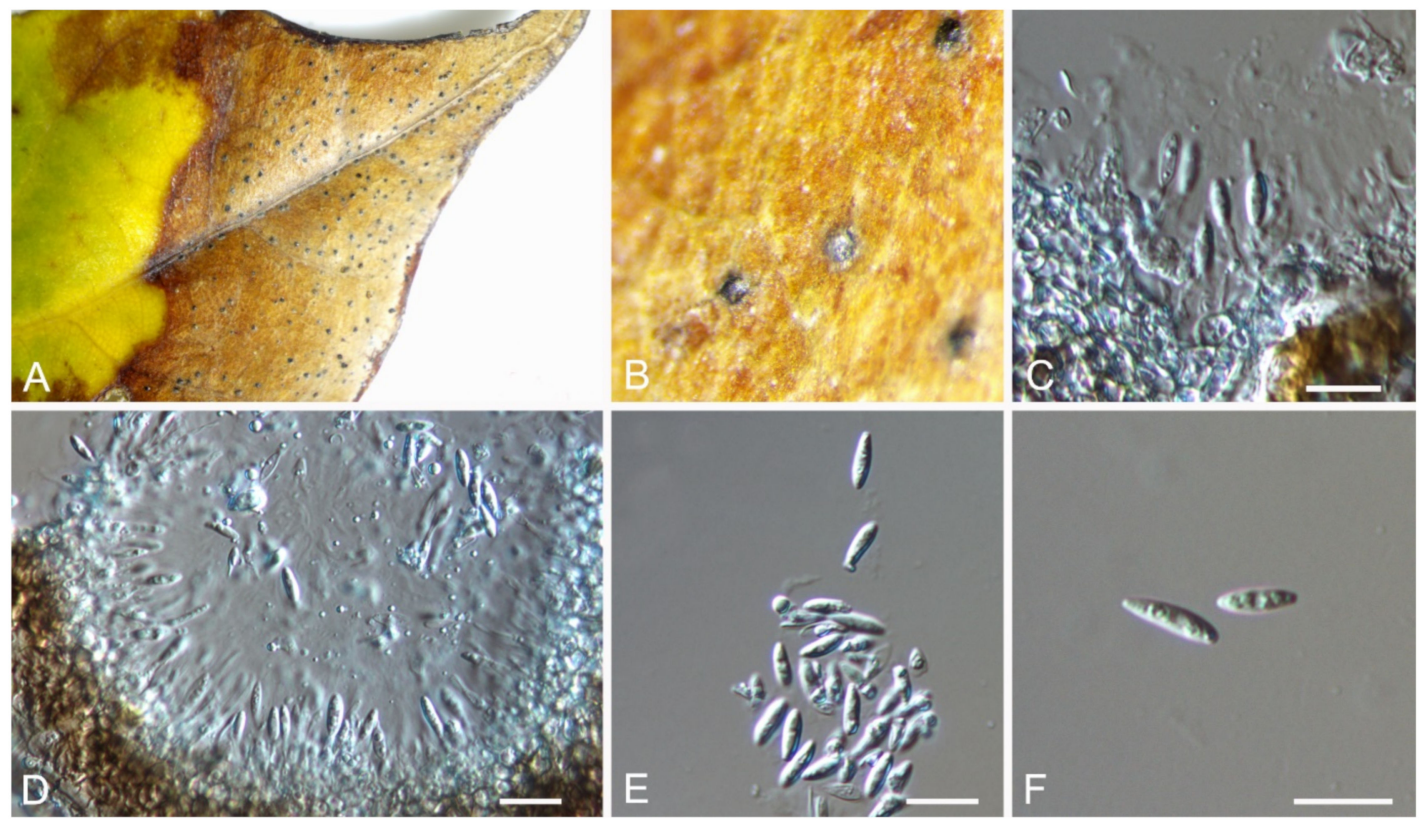

Figure 21. Diaporthe lithocarpi (BJFC-S1809). (A,B) Conidiomata on the diseased leaves of Castanea henryi; (C) Conidiogenous cells giving rise to conidia; (D) Section through the pycnidium; $(\mathbf{E}, \mathbf{F})$ Conidia. Scale bars: $(\mathbf{C}-\mathbf{F})=10 \mu \mathrm{m}$.

\subsection{Gnomoniopsis Berl.}

Gnomoniopsis daii C.M. Tian \& N. Jiang, Forests 10(11/1016): 6 (2019) (Figure 22)

Pathogenic on Castanea mollissima leaves. Sexual morph: Undetermined. Asexual morph: Conidiomata 30-100 $\mu \mathrm{m}$ diam., pycnidial, aggregated, globose to pulvinate, black, single ostiolate, forming long and yellow tendrils. Conidiophores reduced to conidiogenous cells. Conidiogenous cells $2.5-18 \times 1.5-3 \mu \mathrm{m}$, cylindrical, hyaline, phiailidic, unbranched, straight. Conidia (4.9-)5.1-5.9(-6.2) $\times(2.4-) 2.5-2.6(-2.7) \mu \mathrm{m}(\bar{x}=5.5 \times 2.5 \mu \mathrm{m}, n=50)$, $\mathrm{L} / \mathrm{W}=(1.9-) 2-2.2(-2.5)(\bar{x}=2.2, n=50)$, aseptate, hyaline, ellipsoidal, guttulate.

Culture characteristics-Colonies on PDA reaching up to $60 \mathrm{~mm}$ in 7 days, flat, velutinous to shortly woolly, dark brown in center, gradually lightening to pale grey at margin; margin diffuse; reverse dark brown to grey.

Material examined-CHINA, Yunnan Province, Zhaotong City, Zhenxiong County, $27^{\circ} 43^{\prime} 28^{\prime \prime} \mathrm{N}, 105^{\circ} 10^{\prime} 35^{\prime \prime} \mathrm{E}$, alt. $1280 \mathrm{~m}$, on leaf spots of Castanea mollissima, 5 September 2020, N. Jiang (BJFC-S1794, living culture, ZX14-1); Guizhou Province, Zunyi City, Goujiang Town, $27^{\circ} 24^{\prime} 49^{\prime \prime} \mathrm{N}, 106^{\circ} 52^{\prime} 49^{\prime \prime} \mathrm{E}$, alt. $1064 \mathrm{~m}$, on leaf spots of Castanea mollissima, 7 September 2020, N. Jiang (BJFC-S1795, living culture, CFCC 54345 = ZY11); ibid. (living cultures, ZY10-1, ZY10-3, ZY12A).

Notes-The fungus Gnomoniopsis smithogilvyi causes fruit rot and branch canker diseases on Castanea sativa in Australia and Europe [4,5]. Interestingly, similar symptoms on Castanea mollissima in China were caused by two different species. Gnomoniopsis chinese causes branch canker, and G. daii causes fruit rot [54,55]. In this study, we confirmed the Gnomoniopsis pathogen on leaves in China as G. daii based on the phylogenetic inference of ITS, tef1 and tub2 sequence data (Figure A10), and exactly matched morphology. 

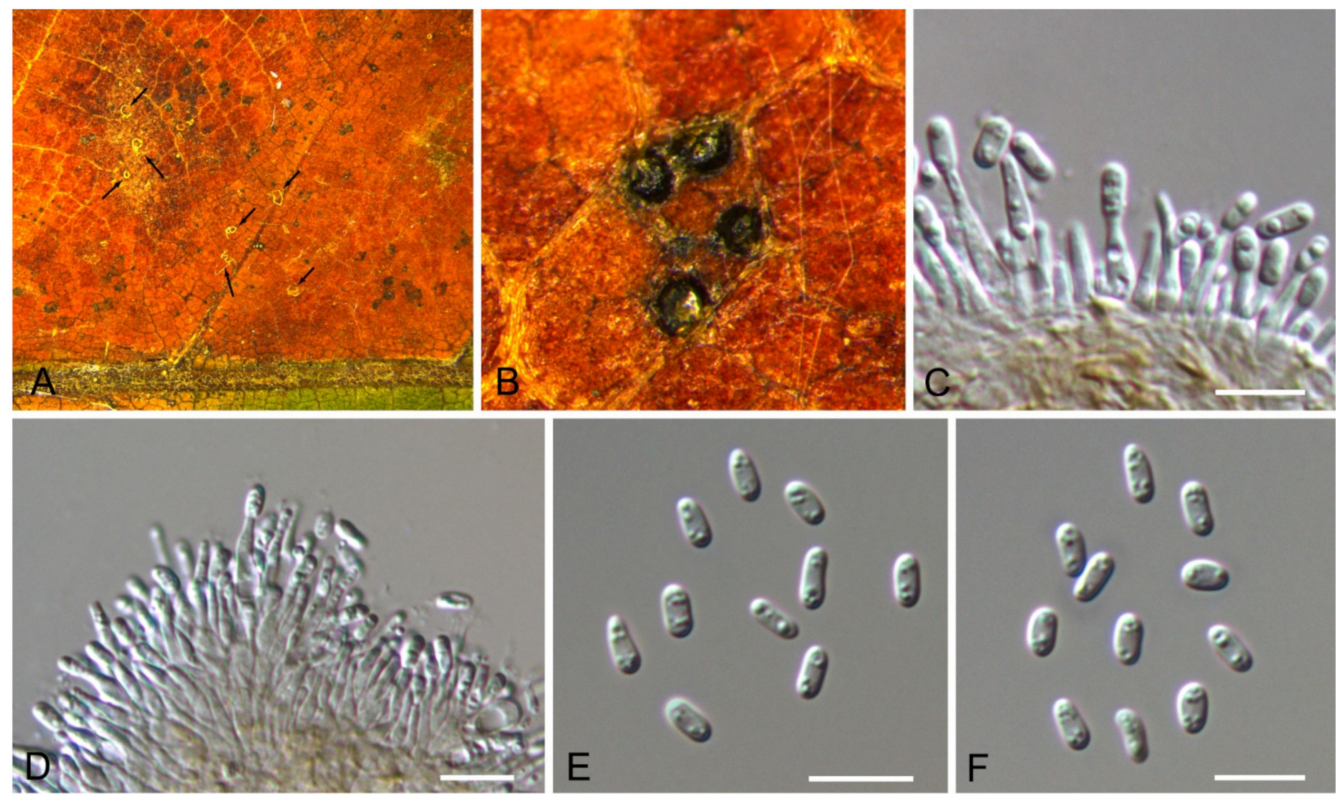

Figure 22. Gnomoniopsis daii (BJFC-S1794). (A,B) Conidiomata on the diseased leaves of Castanea mollissima (arrows showing orange tendrils); (C,D) Conidiogenous cells giving rise to conidia; (E,F) Conidia. Scale bars: $(\mathbf{C}-\mathbf{F})=10 \mu \mathrm{m}$.

3.15. Pyrisporaceae C.M. Tian \& N. Jiang

3.15.1. Pyrisporaceae C.M. Tian \& N. Jiang, fam. nov.

\section{MycoBank: MB 838315}

Etymology—named from the type genus, Pyrispora.

Type genus-Pyrispora C.M. Tian \& N. Jiang

Pathogenic or saprobic on Castanea mollissima leaves. Sexual morph: Ascomata semiimmersed, aggregated, globose to pulvinate, black, single ostiolate. Ostioles single, dark grey to black. Paraphyses deliquescent. Asci cylindrical to clavate, 8-spored, bi-seriate, with a distinct apical ring. Ascospores aseptate, hyaline, smooth, fusoid, multiguttulate, straight to slight curved. Asexual morph: Conidiomata pycnidial, aggregated, globose to subglobose, black, single ostiolate. Conidiophores reduced to conidiogenous cells. Conidiogenous cells pyriform base with long neck, hyaline, phiailidic, unbranched, straight. Conidia aseptate, hyaline, smooth, ellipsoidal, multiguttulate.

Notes-The fungal order Diaporthales was well-classified based on both morphology and phylogeny in recent years (Figure 23) [56-59]. In this study, the sexual morph was observed on Castanea leaves, showing the typical characters of Diaporthales, the asci with distinct apical ring. Additionally, the asexual morph is distinctive based on the conidiogenous cells with pyriform base and long neck. Hence, we proposed a new family to accommodate this species. 


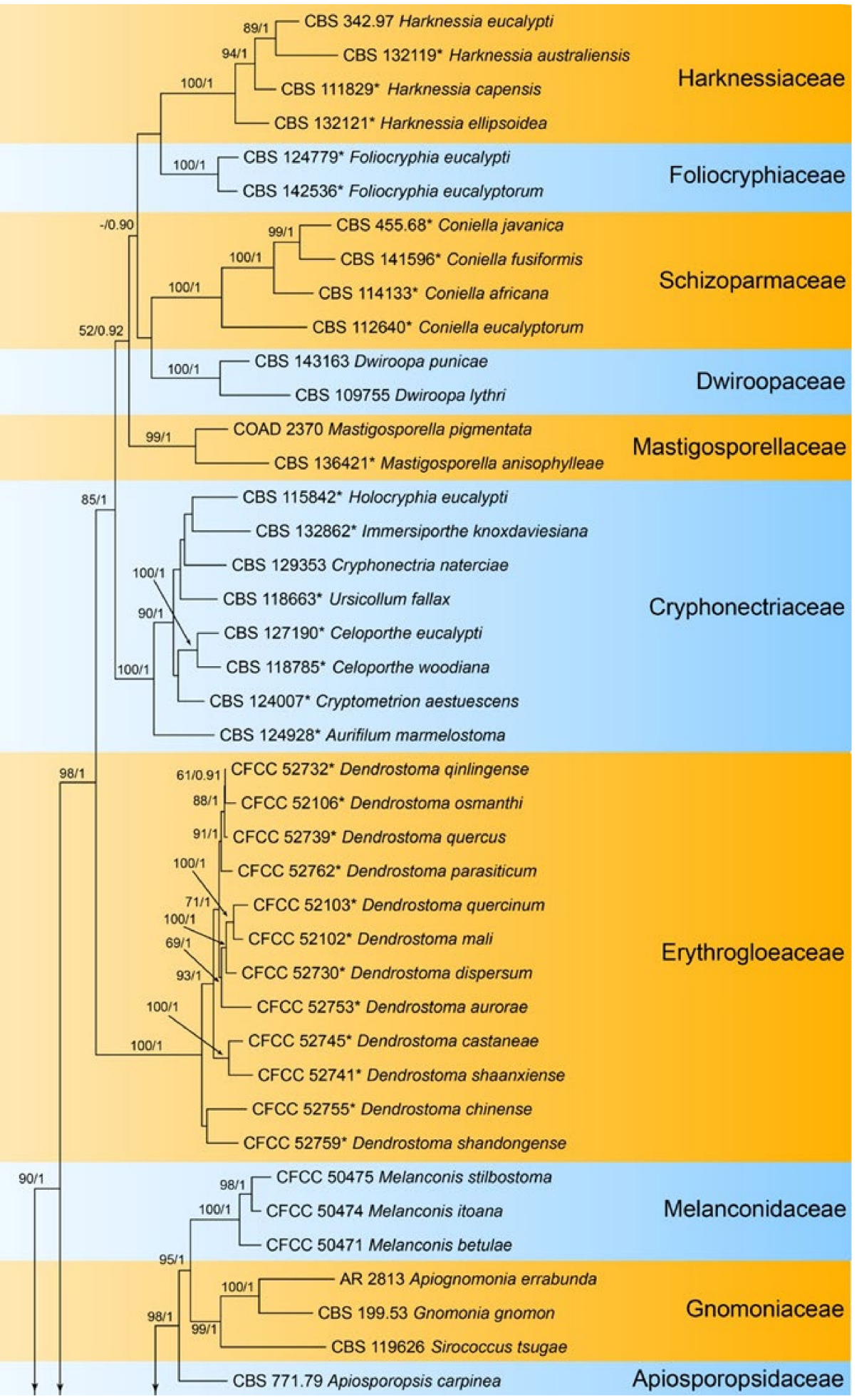

Figure 23. Cont. 


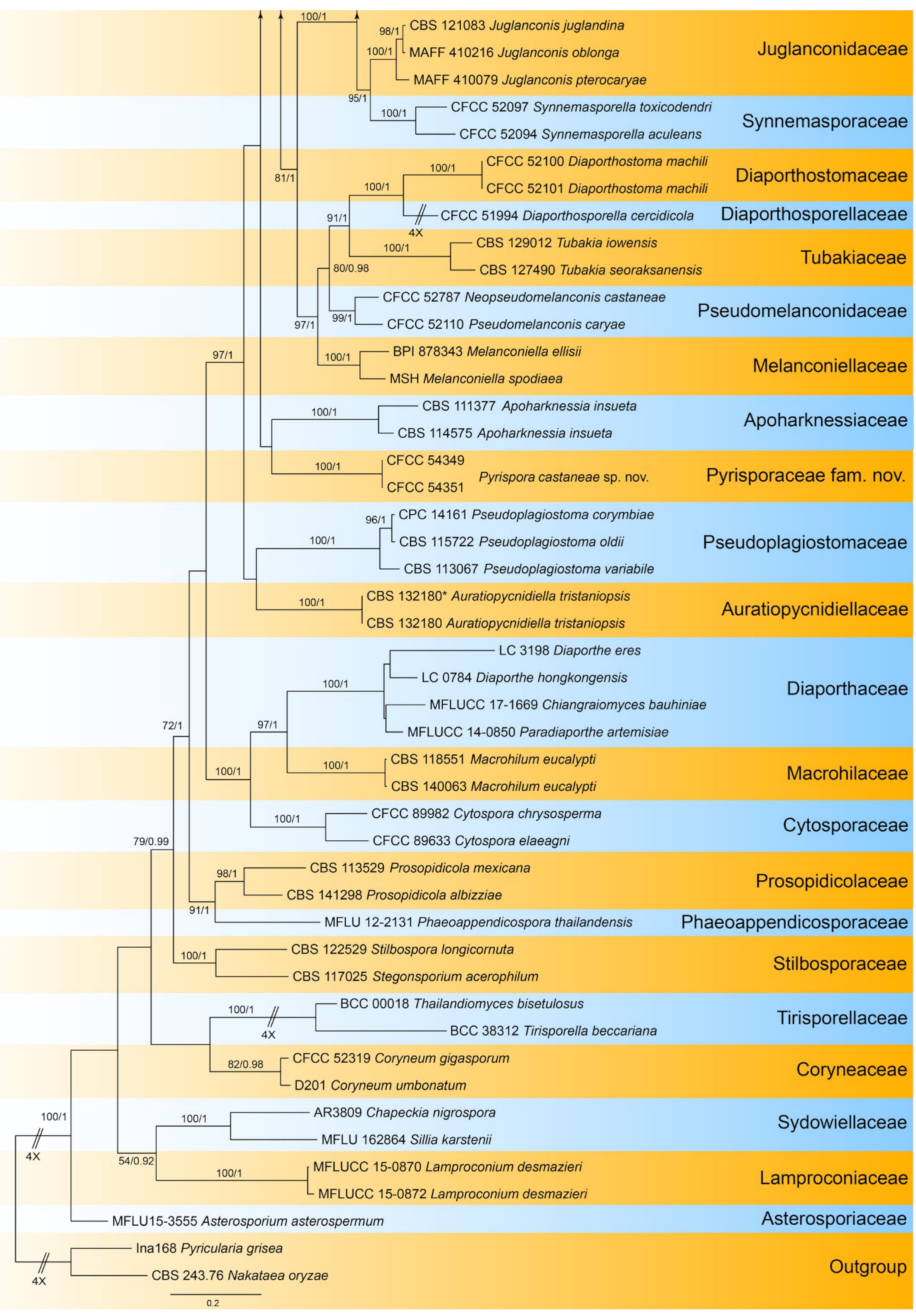

Figure 23. Phylogram generated from RAxML analysis based on combined ITS, LSU, tef1 and $r p b 2$ sequence data of Diaporthales isolates. The tree was rooted to Pyricularia grisea (Ina 168) and Nakataea oryzae (CBS 243.76). The scale bar indicates 0.2 nucleotide changes per site. 
3.15.2. Pyrispora C.M. Tian \& N. Jiang, gen. nov.

MycoBank: MB 838316

Etymology—named for the pyriform base of the conidiogenous cells.

Type species-Pyrispora castaneae C.M. Tian \& N. Jiang

Pathogenic or saprobic on Castanea mollissima leaves. Sexual morph: Ascomata semiimmersed, aggregated, globose to pulvinate, black, single ostiolate. Ostioles single, dark grey to black. Paraphyses deliquescent. Asci cylindrical to clavate, 8-spored, bi-seriate, with a distinct apical ring. Ascospores aseptate, hyaline, smooth, fusoid, multiguttulate, straight to slight curved. Asexual morph: Conidiomata pycnidial, aggregated, globose to subglobose, black, single ostiolate. Conidiophores reduced to conidiogenous cells. Conidiogenous cells pyriform base with long neck, hyaline, phiailidic, unbranched, straight. Conidia aseptate, hyaline, smooth, ellipsoidal, multiguttulate.

\subsubsection{Pyrispora castaneae C.M. Tian \& N. Jiang, sp. nov.}

MycoBank: MB 838317

Etymology—named for the host genus, Castanea.

Holotype-BJFC-S1798

Pathogenic or saprobic on Castanea mollissima leaves. Sexual morph: Ascomata 80-200 $\mu \mathrm{m}$ diam., semi-immersed, aggregated, globose to pulvinate, black, single ostiolate. Ostioles 30-75 $\mu \mathrm{m}$, diam., single, dark grey to black. Paraphyses deliquescent. Asci (41-)44.5-52(-58) $\times(7-) 8.5-10.5(-11) \mu \mathrm{m}$, cylindrical to clavate, 8-spored, bi-seriate, with a distinct apical ring. Ascospores (11.4-)12.2-14.5(-14.9) $\times(4.3-) 4.4-4.9(-5.2) \mu \mathrm{m}$ $(\bar{x}=13.3 \times 4.7 \mu \mathrm{m}, n=50), \mathrm{L} / \mathrm{W}=(2.2-) 2.5-3(-3.2)(\bar{x}=2.9, n=50)$, aseptate, hyaline, smooth, fusoid, multiguttulate, straight to slight curved. Asexual morph: Conidiomata 60-250 $\mu \mathrm{m}$ diam., pycnidial, aggregated, globose to subglobose, black, single ostiolate. Conidiophores reduced to conidiogenous cells. Conidiogenous cells 4-7.5 $\times 2-3.5 \mu \mathrm{m}$, pyriform base with long neck, necks up to $45 \mu \mathrm{m}$, hyaline, phiailidic, unbranched, straight. Conidia (10.4-)11.7-13(-13.9) $\times(4.1-) 4.4-4.9(-5.5) \mu \mathrm{m}(\bar{x}=12.3 \times 4.5 \mu \mathrm{m}, n=50), \mathrm{L} / \mathrm{W}=$ $(2.2-) 2.5-3.2(-3.4)(\bar{x}=2.8, n=50)$, aseptate, hyaline, smooth, ellipsoidal, multiguttulate (Figures 24 and 25).
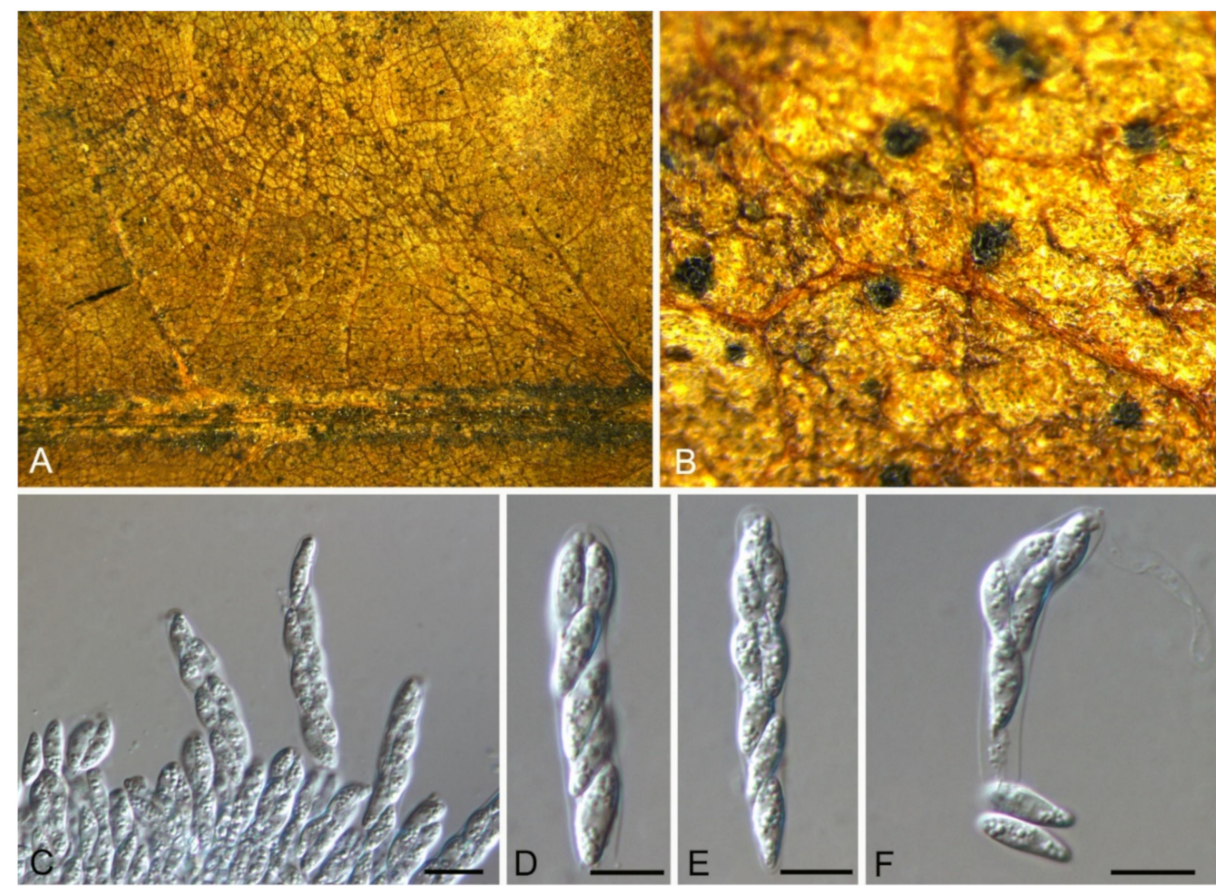

Figure 24. Pyrispora castaneae (BJFC-S1800). (A,B) Ascomata on the diseased leaves of Castanea mollissima; (C-F) Asci and ascospores. Scale bars: $(\mathbf{C}-\mathbf{F})=10 \mu \mathrm{m}$. 

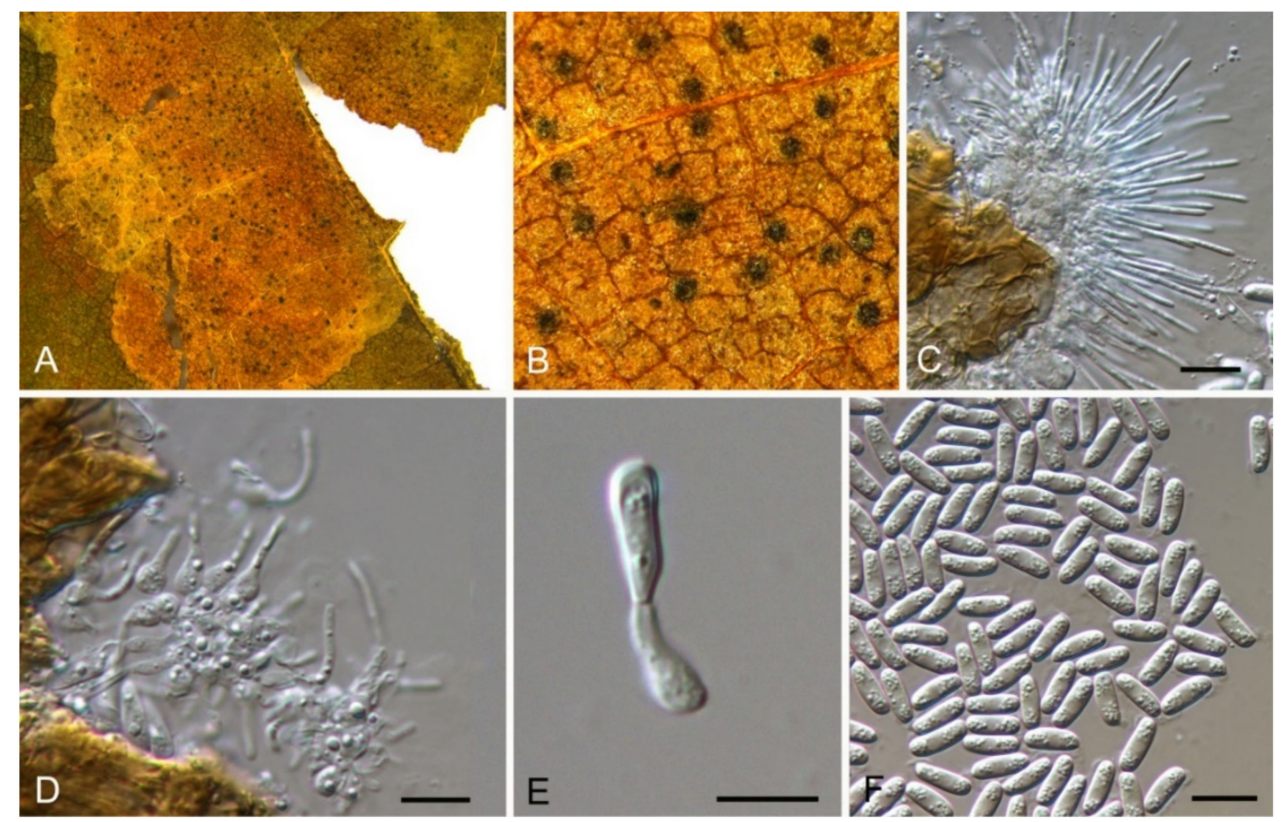

Figure 25. Pyrispora castaneae (BJFC-S1798). (A,B) Conidiomata on the diseased leaves of Castanea mollissima; (C-E) Conidiogenous cells giving rise to conidia; $(\mathbf{F})$ Conidia. Scale bars: $(\mathbf{C}-\mathbf{F})=10 \mu \mathrm{m}$.

Culture characteristics-Colonies on PDA reaching up to $60 \mathrm{~mm}$ in 7 days, flat, white, with cottony aerial mycelium and fringed margin; reverse pale yellowish.

Material examined-CHINA, Sichuan Province, Yaan City, Shimian County, $29^{\circ} 13^{\prime} 31^{\prime \prime} \mathrm{N}$, $102^{\circ} 21^{\prime} 27^{\prime \prime}$ E, alt. $978 \mathrm{~m}$, on leaf spots of Castanea mollissima, 10 September 2020, N. Jiang (BJFC-S1798, holotype; ex-type living culture, CFCC 54349 = SM17); ibid. (BJFC-S1799, living culture, CFCC 54350 = SM20); ibid. (BJFC-S1800, living culture, SM28); ibid. (BJFCS1801, living culture, CFCC 54351 = SM29); ibid. (BJFC-S1802, living culture, SM30); ibid. (BJFC-S1803, living culture, SM31); Hunan Province, Xiangtan City, $27^{\circ} 48^{\prime} 51^{\prime \prime} \mathrm{N}, 112^{\circ} 71^{\prime} 42^{\prime \prime}$ E, alt. 85 m, on leaf spots of Castanea mollissima, 9 November 2020, C.M. Tian \& N. Jiang (living culture, CFCC $54578=$ XT01).

\subsection{Coniella Höhn.}

Coniella castaneicola B. Sutton, The Coelomycetes (Kew): 420 (1980) (Figure 26)

Pathogenic on Castanea mollissima leaves. Sexual morph: Undetermined. Asexual morph: Conidiomata 100-150 $\mu \mathrm{m}$ diam., pycnidial, conspicuous, scattered, globose to subglobose, black, single ostiolate. Conidiophores reduced to conidiogenous cells. Conidiogenous cells 4-13.5 $\times 1.5-3.5 \mu \mathrm{m}$, simple, hyaline, smooth, tapering. Conidia (16.7-)18.421.3(-22.3) $\times(2.7-) 2.8-3.2(-3.3) \mu \mathrm{m}(\bar{x}=19.9 \times 3 \mu \mathrm{m}, n=50), \mathrm{L} / \mathrm{W}=(5.1-) 6-7.2(-7.3)$ $(\bar{x}=6.6, n=50)$, aseptate, initially hyaline, becoming pale brown, smooth, cylindrical, linear, apex acute to nearly rounded, base truncate, smooth-walled, multiguttulate, enclosed in a persistent mucoid sheath.

Culture characteristics-Colonies on PDA reaching up to $60 \mathrm{~mm}$ in 10 days, flat, white, aerial mycelium spreads in irregular concentric zones. Conidiomata were formed after 15 days.

Material examined-CHINA, Guizhou Province, Zunyi City, Goujiang Town, $27^{\circ} 24^{\prime} 49^{\prime \prime} \mathrm{N}$, $106^{\circ} 52^{\prime} 49^{\prime \prime}$ E, alt. $1064 \mathrm{~m}$, on leaf spots of Castanea mollissima, 7 September 2020, N. Jiang (BJFC-S1793, living culture, CFCC 54344 = ZY7-1); ibid. (living culture, ZY7-2).

Notes-The genus Coniella was well classified recently [60]. However, Coniella castaneicola was not studied for lacking of fresh collections and DNA data. In present study, we obtained fresh Coniella isolates from Castanea mollissima, and found it distinct from others in the phylogram (Figure A11). However, specimen in present study shared similar conidial morphology with the original description of Coniella castaneicola $(20 \times 2-2.5 \mu \mathrm{m})$ [61], hence we temporarily assign it to $C$. castaneicola. 

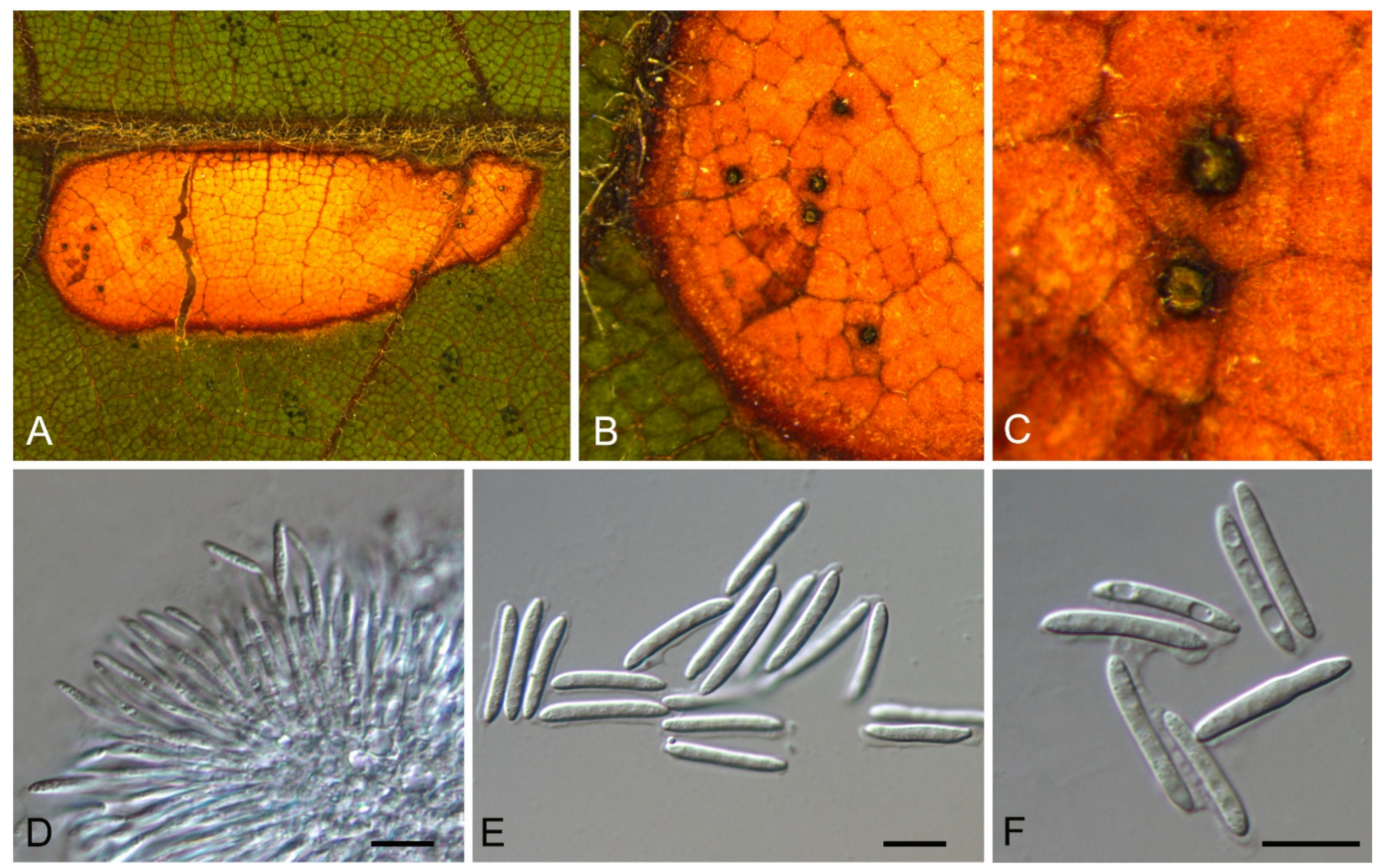

Figure 26. Coniella castaneicola (BJFC-S1793). (A-C) Conidiomata on the diseased leaves of Castanea mollissima; (D) Conidiogenous cells giving rise to conidia; $(\mathbf{E}, \mathbf{F})$ Conidia. Scale bars: $(\mathbf{D}-\mathbf{F})=10 \mu \mathrm{m}$.

\subsection{Tubakia B. Sutton}

Tubakia dryinoides C. Nakash., Fungal Systematics and Evolution 1: 80 (2018) (Figure 27) Pathogenic or saprobic on Castanea mollissima leaves. Sexual morph: Undetermined. Asexual morph: Conidiomata 70-120 $\mu \mathrm{m}$ diam., pycnothyrial, conspicuous, aggregated, superficial, circular or subcircular, black. Conidiophores reduced to conidiogenous cells, arising from the underside of the scutella, around the columella, radiating. Conidiogenous cells 5-14 $\times 2.5-5 \mu \mathrm{m}$, cylindrical, conical, hyaline to brown, thin-walled, smooth, apex obtuse to truncate. Conidia (10.4-)11.5-15.6(-17.7) $\times(5.1-) 5.3-6.1(-6.5) \mu \mathrm{m}(\bar{x}=13.6 \times 5.7 \mu \mathrm{m}$, $n=50), \mathrm{L} / \mathrm{W}=(1.7-) 1.9-2.9(-3.4)(\bar{x}=2.4, n=50)$, aseptate, hyaline to pale brown, smooth, cylindrical to obovoid.

Culture characteristics-Colonies on PDA reaching up to $60 \mathrm{~mm}$ in 14 days, flat, creamy white, aerial mycelium forming concentric rings. Conidiomata were formed after 15 days.

Material examined-CHINA, Sichuan Province, Yaan City, Shimian County, $29^{\circ} 13^{\prime} 31^{\prime \prime} \mathrm{N}$, $102^{\circ} 21^{\prime} 27^{\prime \prime}$ E, alt. $978 \mathrm{~m}$, on leaf spots of Castanea mollissima, 10 September 2020, N. Jiang (BJFC-S1796; living culture, CFCC 54346 = SM10-1); ibid. (living culture, = SM10).

Notes-Tubakia dryinoides was described from Castanea crenata and Quercus phillyraeoides in Japan [62]. In present study, strains from diseased chestnut leaves formed a supported clade with the ex-type strain NBRC 9267 (Figure A12), and shared similar morphology. Hence, we identified our strains as T. dryinoides, which represented a new host and geographical record. 


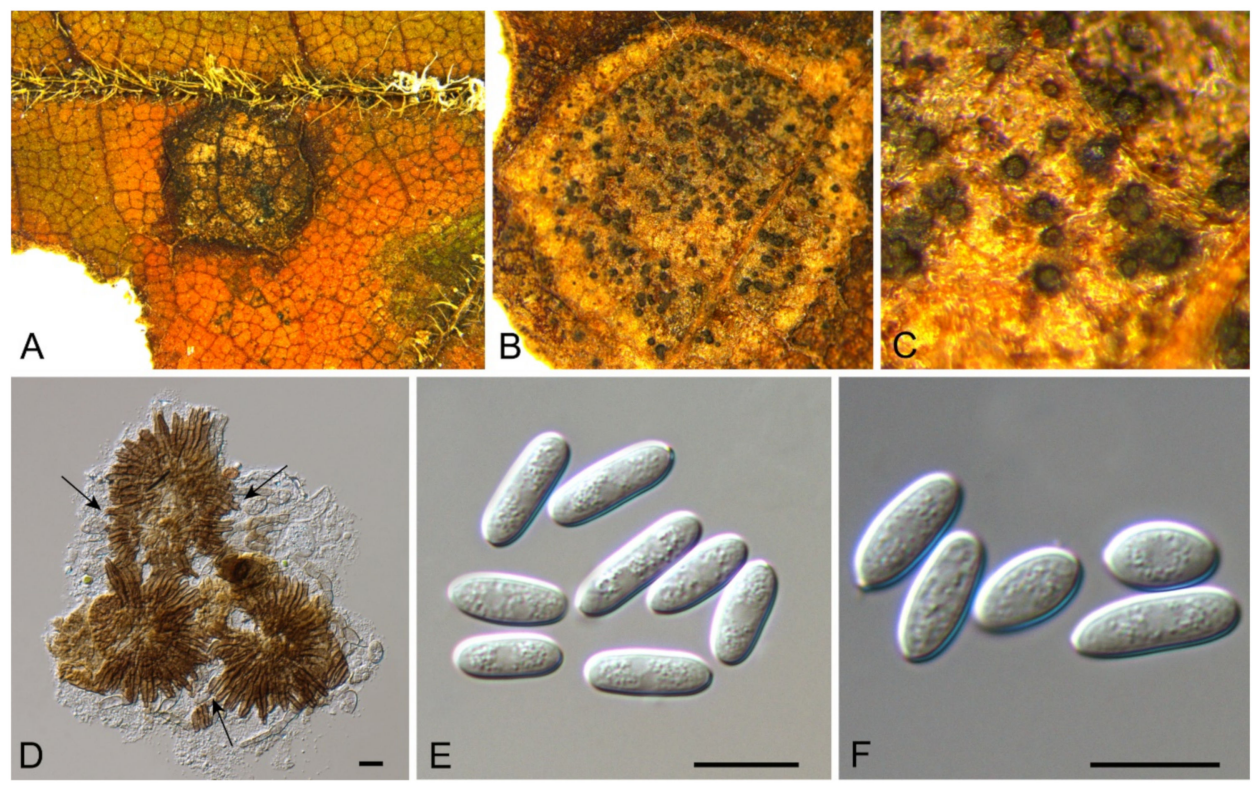

Figure 27. Tubakia dryinoides (BJFC-S1796). (A-C) Pycnothyria on the diseased leaves of Castanea mollissima; (D) Conidiogenous cells giving rise to conidia; $(\mathbf{E}, \mathbf{F})$ Conidia. Scale bars: $(\mathbf{D}-\mathbf{F})=10 \mu \mathrm{m}$.

\subsection{Colletotrichum Corda}

\subsubsection{Colletotrichum fructicola}

Colletotrichum fructicola Prihast., L. Cai \& K.D. Hyde, Fungal Divers. 39: 96 (2009)

Pathogenic on Castanea henryi and C. mollissima leaves. Sexual morph: Undetermined. Asexual morph was observed on PDA: Conidiomata, acervular, aggregated, orange. Conidiophores hyaline, septate, branched. Conidiogenous cells 5-17.5 × 1.5-3 $\mu \mathrm{m}$, hyaline, cylindrical to ampulliform. Conidia (10.8-)11.2-16.9(-17.9) $\times(3.1-) 3.2-5.4(-5.9) \mu \mathrm{m}$ $(\bar{x}=14.7 \times 4.3 \mu \mathrm{m}, n=50), \mathrm{L} / \mathrm{W}=(3.1-) 3.2-3.5(-3.6)(\bar{x}=3.4, n=50)$, aseptate, hyaline, smooth, cylindrical, both ends rounded.

Culture characteristics-Colonies on PDA reaching up to $60 \mathrm{~mm}$ in 5 days, flat with entire edge, aerial mycelium dense, cottony, grey to dark grey in the centre, white at the margin; reverse greyish green.

Material examined-CHINA, Sichuan Province, Yaan City, Shimian County, $29^{\circ} 13^{\prime} 31^{\prime \prime} \mathrm{N}$, $102^{\circ} 21^{\prime} 27^{\prime \prime}$ E, alt. $978 \mathrm{~m}$, on leaf spots of Castanea mollissima, 10 September 2020, N. Jiang (living cultures, SM6, SM9, SM13, SM14, SM14, SM16, SM30, SM31); Hunan Province, Shaoshan City, Yintian Town, $27^{\circ} 52^{\prime} 04^{\prime \prime} \mathrm{N}, 112^{\circ} 35^{\prime} 03^{\prime \prime} \mathrm{E}$, alt. $73 \mathrm{~m}$, on leaf spots of Castanea mollissima, 9 November 2020, C.M. Tian \& N. Jiang (living cultures, SS01, SS14); Hunan Province, Xiangtan City, $27^{\circ} 48^{\prime} 51^{\prime \prime} \mathrm{N}, 112^{\circ} 71^{\prime} 42^{\prime \prime} \mathrm{E}$, alt. $85 \mathrm{~m}$, on leaf spots of Castanea mollissima, 9 November 2020, N. Jiang (living cultures, XT08, XT12, XT14-2, XT15); Hunan Province, Changsha City, Changsha County, Jinjing Town, $28^{\circ} 58^{\prime} 52^{\prime \prime} \mathrm{N}, 113^{\circ} 34^{\prime} 38^{\prime \prime} \mathrm{E}$, alt. $63 \mathrm{~m}$, on leaf spots of Castanea henryi, 10 November 2020, C.M. Tian \& N. Jiang (living culture, JJ21).

Notes-Colletotrichum fructicola was described from Coffea arabica in Thailand [63], and subsequently found to infect several economic plants in China, such as Camellia sinensis, Citrus sinensis, Morus alba, Pyrus pyrifolia and Vitis vinifera [64]. In present study, strains from diseased chestnut leaves formed a supported clade with Colletotrichum fructicola (Figure A13), and shared similar morphology. Hence, we identified our strains as C. fructicola, and Castanea henryi and C. mollissima represented two new host records.

\subsubsection{Colletotrichum henanense}

Colletotrichum henanense F. Liu \& L. Cai, Persoonia 35: 80 (2015)

Pathogenic on Castanea mollissima leaves. Sexual morph: Undetermined. Asexual morph was observed on PDA: Conidiomata, acervular, aggregated, orange. Conidiophores 
hyaline, septate, branched. Conidiogenous cells 4.5-15 $\times 1.5-2.5 \mu \mathrm{m}$, hyaline, cylindrical to ampulliform. Conidia (8.8-)11.5-13.2(-17.2) $\times(3-) 3.4-5.1(-5.8) \mu \mathrm{m}(\bar{x}=12.2 \times 4.3 \mu \mathrm{m}$, $n=50), \mathrm{L} / \mathrm{W}=(2.5-) 2.6-2.9(-3)(\bar{x}=2.7, n=50)$, aseptate, hyaline, smooth, cylindrical, both ends rounded.

Culture characteristics-Colonies on PDA reaching up to $60 \mathrm{~mm}$ in 5 days, flat with entire edge, aerial mycelium dense, cottony, grey to dark grey in the centre, white at the margin; reverse greyish green.

Material examined-CHINA, Sichuan Province, Yaan City, Shimian County, $29^{\circ} 13^{\prime} 31^{\prime \prime} \mathrm{N}$, $102^{\circ} 21^{\prime} 27^{\prime \prime}$ E, alt. $978 \mathrm{~m}$, on leaf spots of Castanea mollissima, 10 September 2020, N. Jiang (living cultures, SM12, SM22, SM33); Hunan Province, Shaoshan City, Yintian Town, $27^{\circ} 52^{\prime} 04^{\prime \prime} \mathrm{N}, 112^{\circ} 35^{\prime} 03^{\prime \prime} \mathrm{E}$, alt. $73 \mathrm{~m}$, on leaf spots of Castanea mollissima, 9 November 2020, C.M. Tian \& N. Jiang (living cultures, SS02, SS04); Yunnan Province, Zhaotong City, Zhenxiong County, $27^{\circ} 43^{\prime} 28^{\prime \prime} \mathrm{N}, 105^{\circ} 10^{\prime} 35^{\prime \prime} \mathrm{E}$, alt. $1280 \mathrm{~m}$, on leaf spots of Castanea mollissima, 5 September 2020, N. Jiang (living culture, ZX2-1); Hunan Province, Changsha City, Changsha County, Kaihui Town, $28^{\circ} 58^{\prime} 12^{\prime \prime} \mathrm{N}, 113^{\circ} 25^{\prime} 48^{\prime \prime}$ E, alt. $65 \mathrm{~m}$, on leaf spots of Castanea mollissima, 10 November 2020, C.M. Tian \& N. Jiang (living culture, KH1).

Notes-Colletotrichum henanense was initially proposed as the leaf pathogen of Camellia sinensis and Cirsium japonicum in China [65]. Later, it was recorded to cause anthracnose of Camellia oleifera in China [66]. In the present study, strains from diseased chestnut leaves formed a supported clade with Colletotrichum henanense (Figure A13), and shared similar morphology. Hence, we identified our strains as C. henanense, and Castanea mollissima represented a new host record.

\subsubsection{Colletotrichum jiangxiense}

Colletotrichum jiangxiense F. Liu \& L. Cai, Persoonia 35: 82 (2015)

Pathogenic on Castanea mollissima leaves. Sexual morph: Undetermined. Asexual morph: Undetermined.

Culture characteristics-Colonies on PDA reaching up to $60 \mathrm{~mm}$ in 7 days, flat with entire edge, aerial mycelium dense, cottony, white to grey; reverse olivaceous.

Material examined-CHINA, Sichuan Province, Yaan City, Shimian County, $29^{\circ} 13^{\prime} 31^{\prime \prime} \mathrm{N}$, $102^{\circ} 21^{\prime} 27^{\prime \prime}$ E, alt. $978 \mathrm{~m}$, on leaf spots of Castanea mollissima, 10 September 2020, N. Jiang (living culture, SM21); Yunnan Province, Zhaotong City, Zhenxiong County, $27^{\circ} 43^{\prime} 28^{\prime \prime} \mathrm{N}$, $105^{\circ} 10^{\prime} 35^{\prime \prime}$ E, alt. $1280 \mathrm{~m}$, on leaf spots of Castanea mollissima, 5 September 2020, N. Jiang (living culture, ZX10-1); Guizhou Province, Zunyi City, Goujiang Town, $27^{\circ} 24^{\prime} 49^{\prime \prime} \mathrm{N}$, $106^{\circ} 52^{\prime} 49^{\prime \prime}$ E, alt. $1064 \mathrm{~m}$, on leaf spots of Castanea mollissima, 7 September 2020, N. Jiang (living cultures, ZY12, ZY12B).

Notes-Colletotrichum jiangxiense was previously described from Camellia sinensis in China [65], and subsequently discovered from Citrus sinensis [67]. In present study, strains from diseased chestnut leaves formed a supported clade with Colletotrichum jiangxiense (Figure A13). Hence, we identified our strains as C. jiangxiense, and Castanea mollissima represented a new host record.

3.18.4. Colletotrichum karsti You L. Yang, Zuo Y. Liu, K.D. Hyde \& L. Cai, Cryptog. Mycol. 32(3): 241 (2011)

Pathogenic on Castanea mollissima leaves. Sexual morph: Undetermined. Asexual morph: Undetermined.

Culture characteristics-Colonies on PDA reaching up to $60 \mathrm{~mm}$ in 6 days, flat with entire margin, aerial mycelium dense, cottony, initially white, becoming grey with age; reverse pale brown.

Material examined-CHINA, Guizhou Province, Zunyi City, Goujiang Town, 27 $24^{\prime} 49^{\prime \prime}$ N, $106^{\circ} 52^{\prime} 49^{\prime \prime}$ E, alt. $1064 \mathrm{~m}$, on leaf spots of Castanea mollissima, 7 September 2020, N. Jiang (living cultures, CFCC 54365 = ZY3B, ZY3B-1).

Notes-Colletotrichum karsti was described from Arundina graminifolia, Calanthe argenteostriata, Eria coronaria, Pleione bulbocodioides and Vanda sp. in China [68]. In the present study, strains from diseased chestnut leaves formed a supported clade with Colletotrichum 
karsti (Figure A14). Hence, we identified our strains as C. karsti, and Castanea mollissima represented a new host record.

3.18.5. Colletotrichum nymphaeae (Pass.) Aa, Netherlands Journal of Plant Pathology, Supplement 1 84(3): 110 (1978)

Pathogenic on Castanea mollissima leaves. Sexual morph: Undetermined. Asexual morph: Undetermined.

Culture characteristics-Colonies on PDA reaching up to $60 \mathrm{~mm}$ in 8 days, flat with entire edge, aerial mycelium dense, cottony, white to grey; reverse olivaceous.

Material examined-CHINA, Sichuan Province, Yaan City, Shimian County, $29^{\circ} 13^{\prime} 31^{\prime \prime} \mathrm{N}$, $102^{\circ} 21^{\prime} 27^{\prime \prime}$ E, alt. $978 \mathrm{~m}$, on leaf spots of Castanea mollissima, 10 September 2020, N. Jiang (living cultures, CFCC 54366 = SM26, SM26-1).

Notes-Colletotrichum nymphaeae was recorded to be associated with several hosts, including Camellia oleifera, Citrus aurantifolia, Juglans regia, Malus domestica, Prunus salicina and Vitis vinifera [69]. In the present study, strains from diseased chestnut leaves formed a supported clade with Colletotrichum nymphaeae (Figure A15). Hence, we identified our strains as C. nymphaeae, and Castanea mollissima represented a new host record.

\section{Discussion}

Castanea henryi and C. mollissima are two crops currently cultivated in plantations of China, and suffering from cankers, leaf spots and fruit rot diseases commonly. During our investigations in the past years, Cryphonectria parasitica and Dendrostoma spp. were commonly occurring in most plantations, causing mild to serious cankers depending on the management $[2,10]$. Gnomoniopsis chinensis caused fatal stem and branch canker disease in only Hebei Province [60]. Compared to the cankers, leaf spots are usually neglected. In present study, we focused on the leaf-inhabiting fungi, identified them to 26 fungal species using phenotypic characters and the multi-locus phylogeny.

From Table 3, most fungi (92.3\%) belong to Sordariomycetes and the rest two species belong to Dothideomycetes. This result is nearly congruent as we expected, because Sordariomycetes is a species-rich class and contains many plant pathogens [69]. Within Sordariomycetes, Amphisphaeriales (45.8\%), Botryosphaeriales (12.5\%), Diaporthales (33.3\%) and Glomerellales $(20.8 \%)$ are identified. They contain famous plant pathogens such as pestalotioid taxa, Botryosphaeria-like taxa, diaporthalean fungi and Colletotrichum species. These fungi were documented in the monograph of chestnut disease by Xie in 1998 [44]. However, genus and species concepts have changed a lot in recent years. For example, the old name Colletotrichum gloeosporioides has been expanded to a group of species named Colletotrichum gloeosporioides species complex [70], hence the chestnut-inhabiting Colletotrichum needs to be re-identified to particular one or several species. The genus Pestalotiopsis s. l. was separated into three genera, namely Pestalotiopsis s. S., Neopestalotiopsis and Pseudopestalotiopsis based on phylogeny [50]. In addition, species with similar morphology from the same host, especially resulting into same symptoms, are not easy to be distinguished without molecular approach in previous studies. Gnomoniopsis daii from Chinese chestnut and Gnomoniopsis smithogilvyi (G. castaneae) from European chestnut were likely identified to Phomopsis (now Diaporthe) species for extremely similar morphology.

According to the filed investigation and sample observation, Colletotrichum spp., Neopestalotiopsis spp., Pestalotiopsis kenyana and Phyllosticta capitalensis are now common pathogens in plantations of Castanea henryi and C. mollissima. Pathogenicity tests and disease control methods are required to be conducted in the future.

Author Contributions: Experiments: N.J.; writing—original draft preparation: N.J.; writing—review and editing: N.J., X.F. and C.T. All authors have read and agreed to the published version of the manuscript.

Funding: This research was funded by the National Natural Science Foundation of China, grant number 31670647. 
Data Availability Statement: All sequence data are available in NCBI GenBank following the accession numbers in the manuscript.

Acknowledgments: We are grateful for the assistance of Yingmei Liang (Museum of Beijing Forestry University), Chungen Piao and Minwei Guo (China Forestry Culture Collection Center) during this study.

Conflicts of Interest: The authors declare no conflict of interest.

\section{Appendix A}

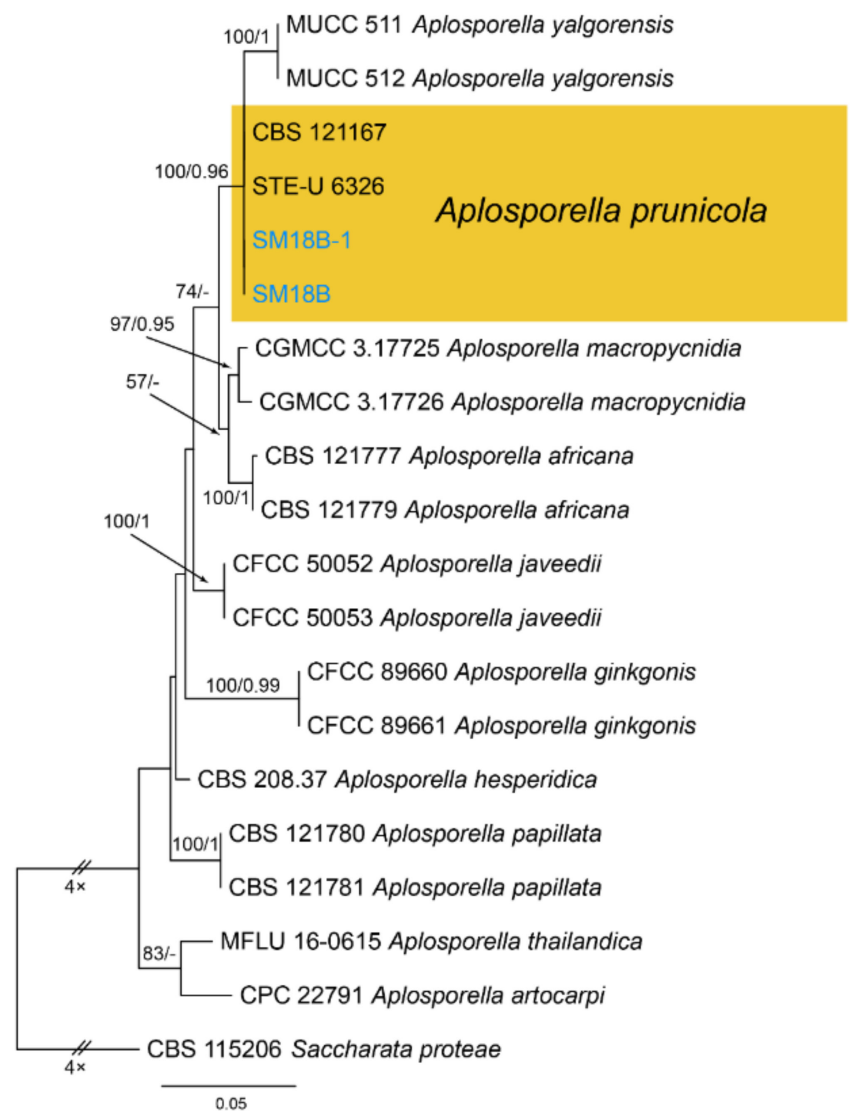

Figure A1. Phylogram generated from RAxML analysis based on combined ITS and tef1 sequence data of Aplosporella isolates. The tree was rooted to Saccharata proteae (CBS 115206). The scale bar indicates 0.05 nucleotide changes per site. Isolates from this study are marked in blue, and the identified species is marked in yellow. 


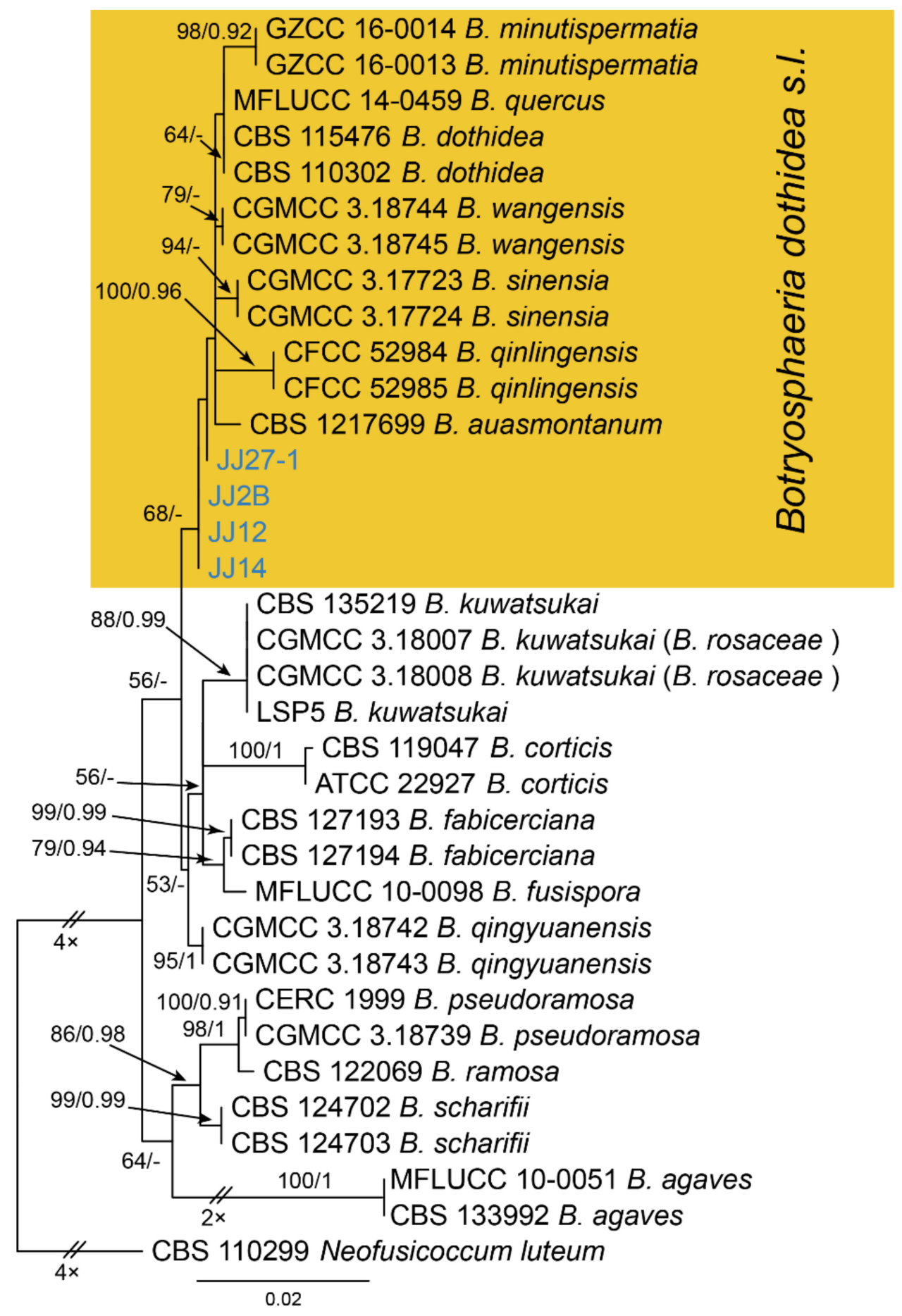

Figure A2. Phylogram generated from RAxML analysis based on combined ITS, tef1 and tub2 sequence data of Botryosphaeria isolates. The tree was rooted to Neofusicoccum luteum (CBS 110229). The scale bar indicates 0.02 nucleotide changes per site. Isolates from this study are marked in blue, and the identified species is marked in yellow. 


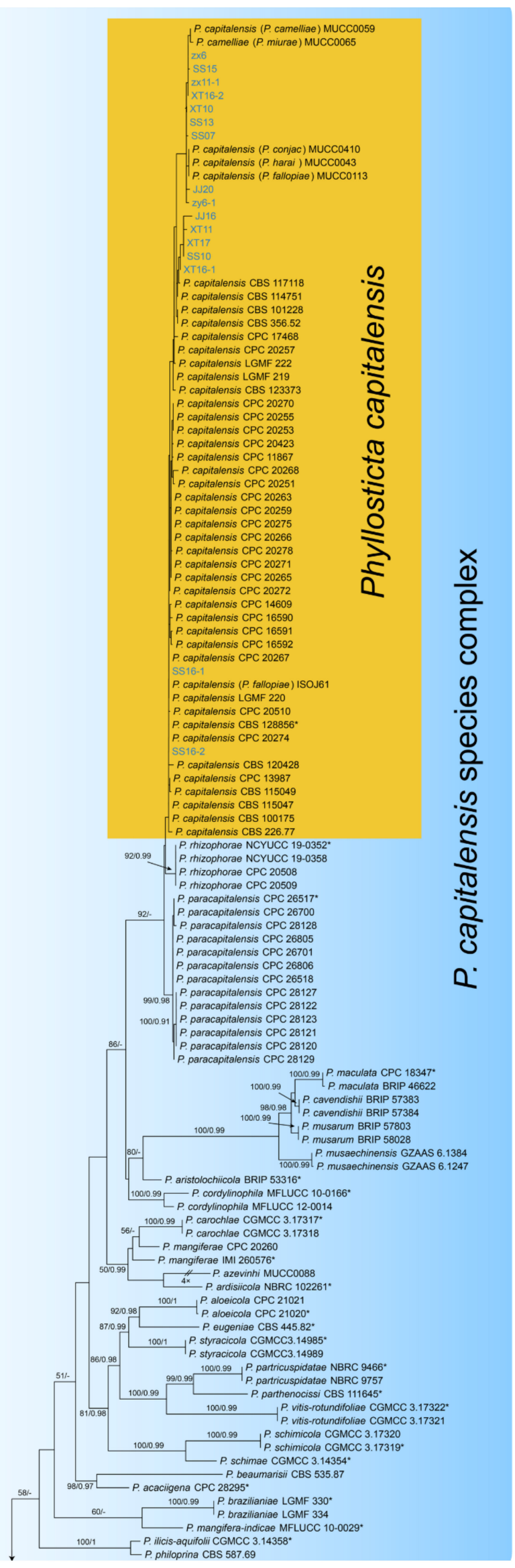

Figure A3. Cont. 


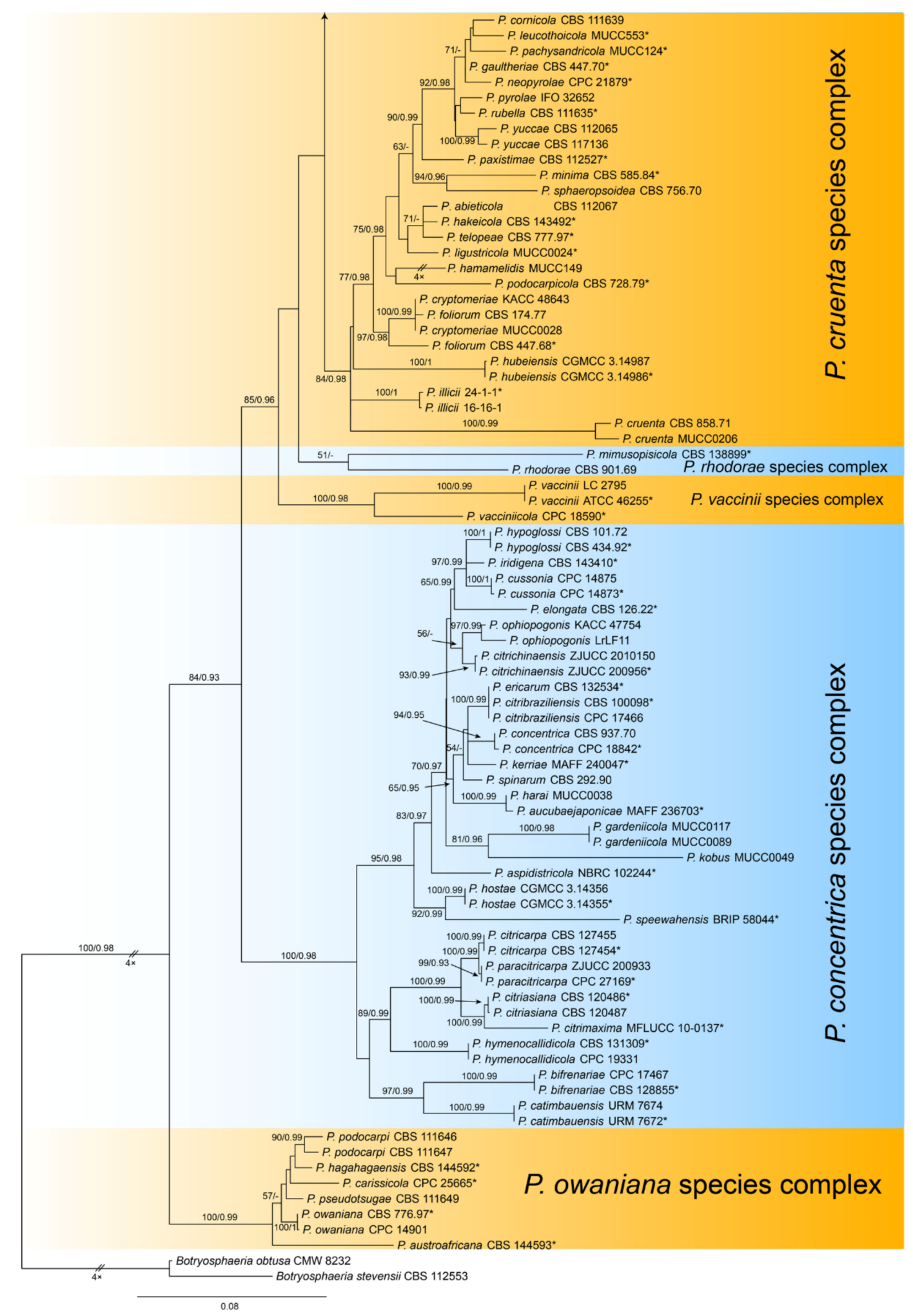

Figure A3. Phylogram generated from RAxML analysis based on combined ITS, LSU, act, gapdh and tef1 sequence data of Phyllosticta isolates. The tree was rooted to Botryosphaeria obtusa (CMW 8232) and B. stevensii (CBS 112553). The scale bar indicates 0.08 nucleotide changes per site. Isolates from this study are highlighted, and ex-type strains are marked with * 


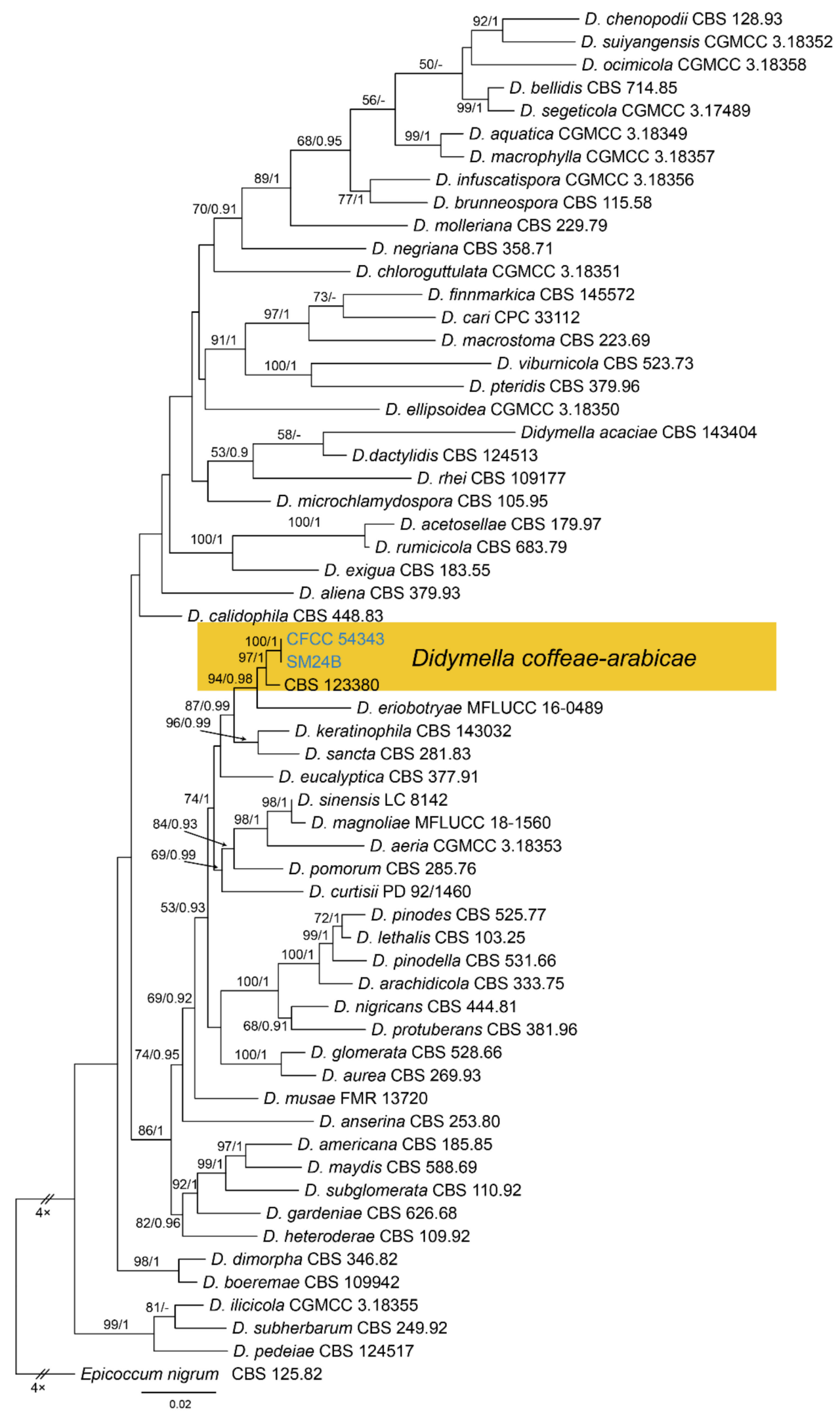

Figure A4. Phylogram generated from RAxML analysis based on combined ITS, LSU, rpb2 and tub2 sequence data of Didymella isolates. The tree was rooted to Epicoccum nigrum (CBS 125.82). The scale bar indicates 0.02 nucleotide changes per site. Isolates from this study are marked in blue, and the identified species is marked in yellow. 


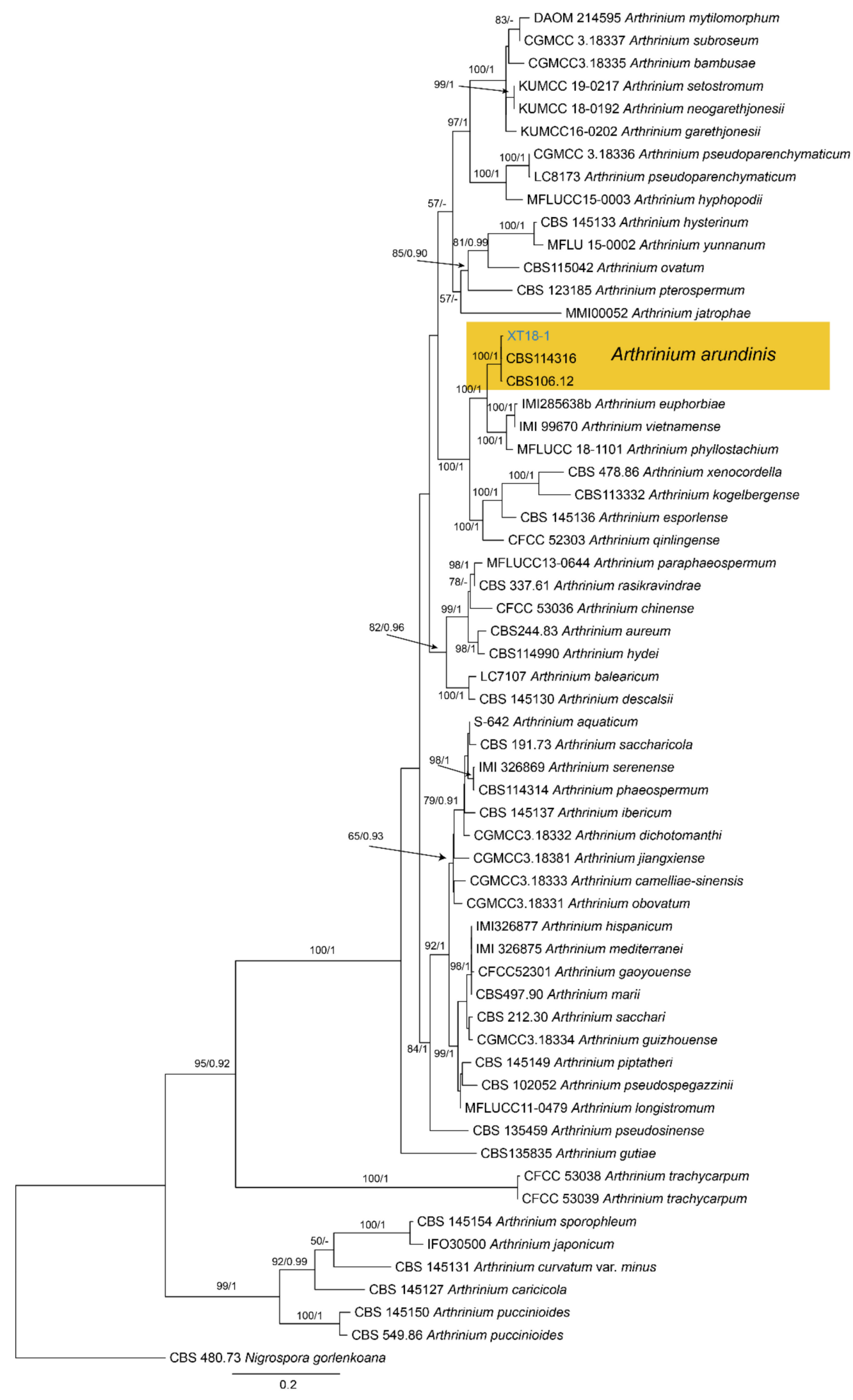

Figure A5. Phylogram generated from RAxML analysis based on combined ITS, tef1 and tub2 sequence data of Arthrinium isolates. The tree was rooted to Nigrospora gorlenkoana (CBS 480.73). The scale bar indicates 0.2 nucleotide changes per site. Isolate from this study is marked in blue, and the identified species is marked in yellow. 


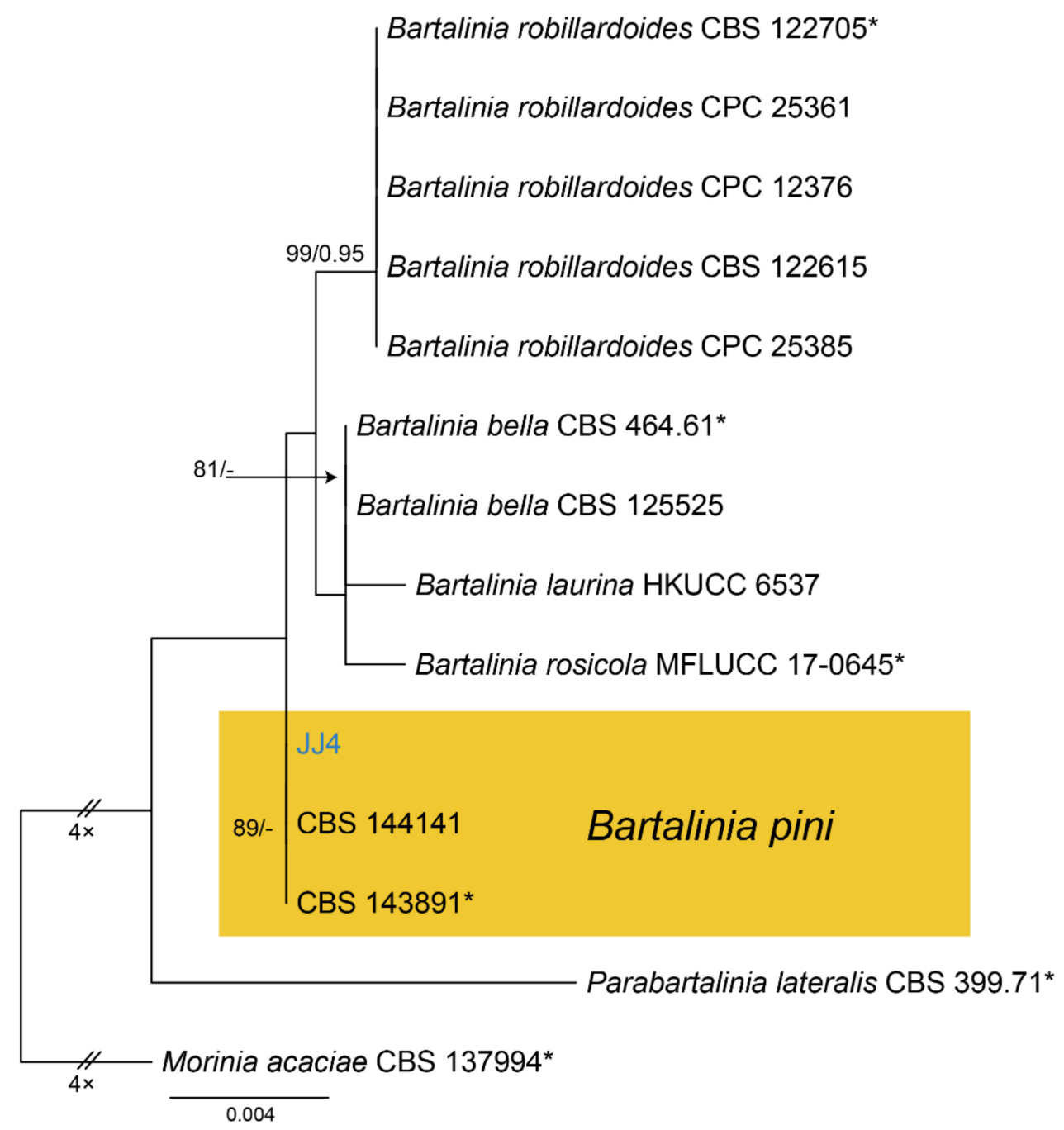

Figure A6. Phylogram generated from RAxML analysis based on combined ITS and LSU sequence data of Bartalinia isolates. Table 137994. The scale bar indicates 0.004 nucleotide changes per site. Isolate from this study is marked in blue, ex-type strains are marked with *, and the identified species is marked in yellow. 


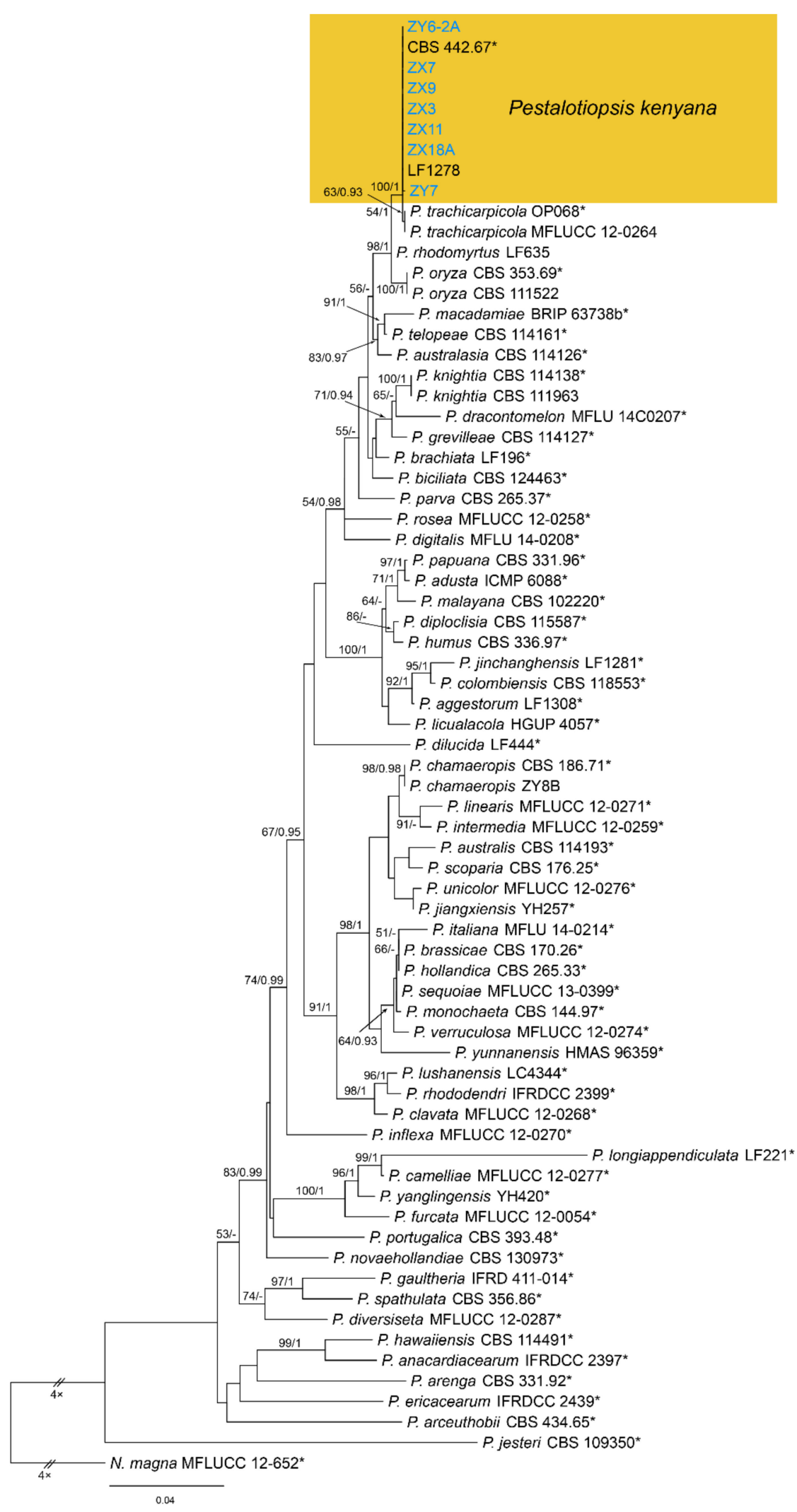

Figure A7. Phylogram generated from RAxML analysis based on combined ITS, tef1 and tub2 sequence data of Pestalotiopsis isolates. The tree was rooted to Neopestalotiopsis magna (MFLUCC 12-652). The scale bar indicates 0.04 nucleotide changes per site. Isolates from this study are marked in blue, ex-type strains are marked with *, and the identified species is marked in yellow. 


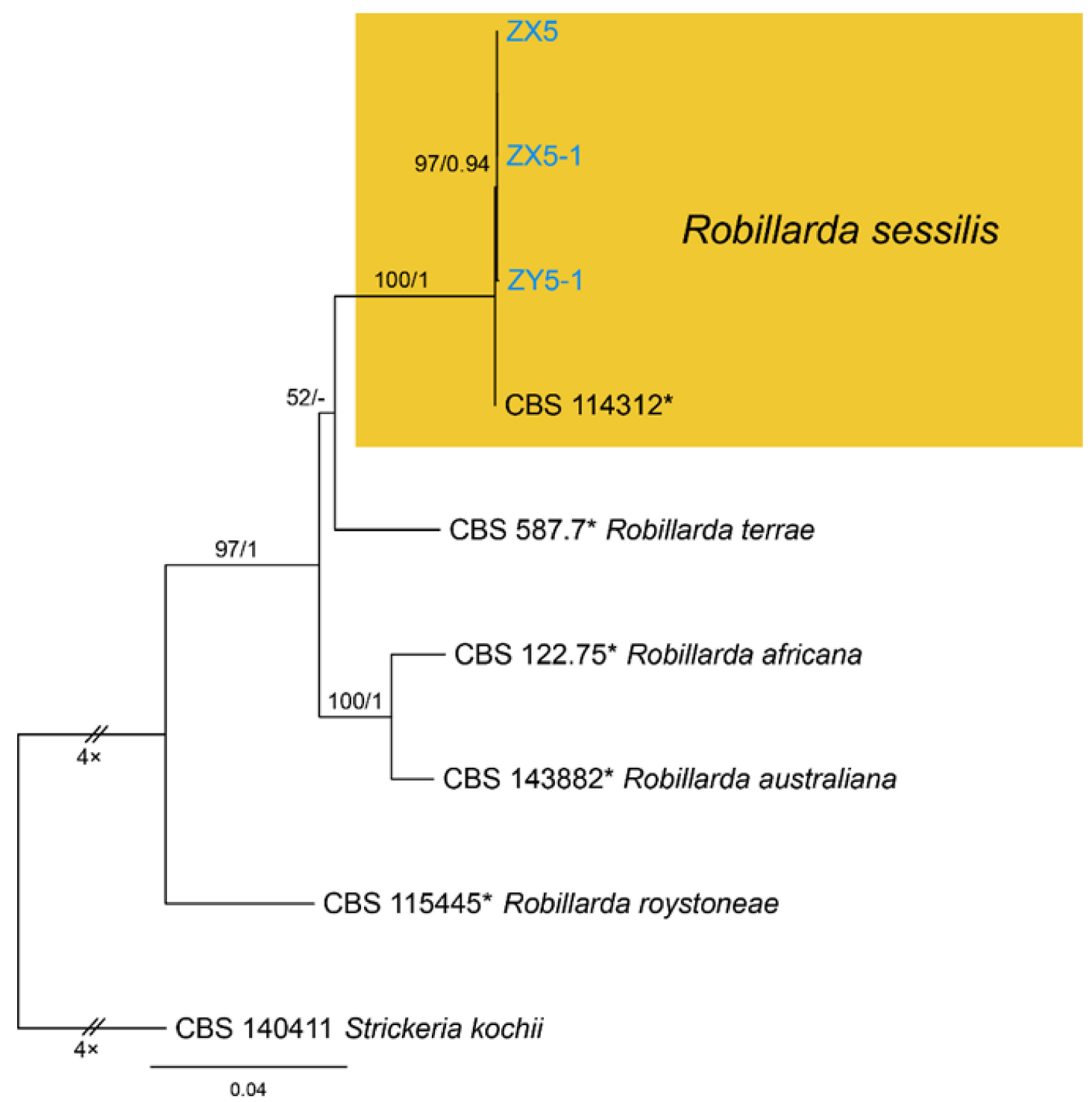

Figure A8. Phylogram generated from RAxML analysis based on combined ITS, LSU, rpb2, tef1 and tub2 sequence data of Robillarda isolates. The tree was rooted to Strickeria kochii (CBS 140411). The scale bar indicates 0.04 nucleotide changes per site. Isolates from this study are marked in blue, ex-type strains are marked with *, and the identified species is marked in yellow. 


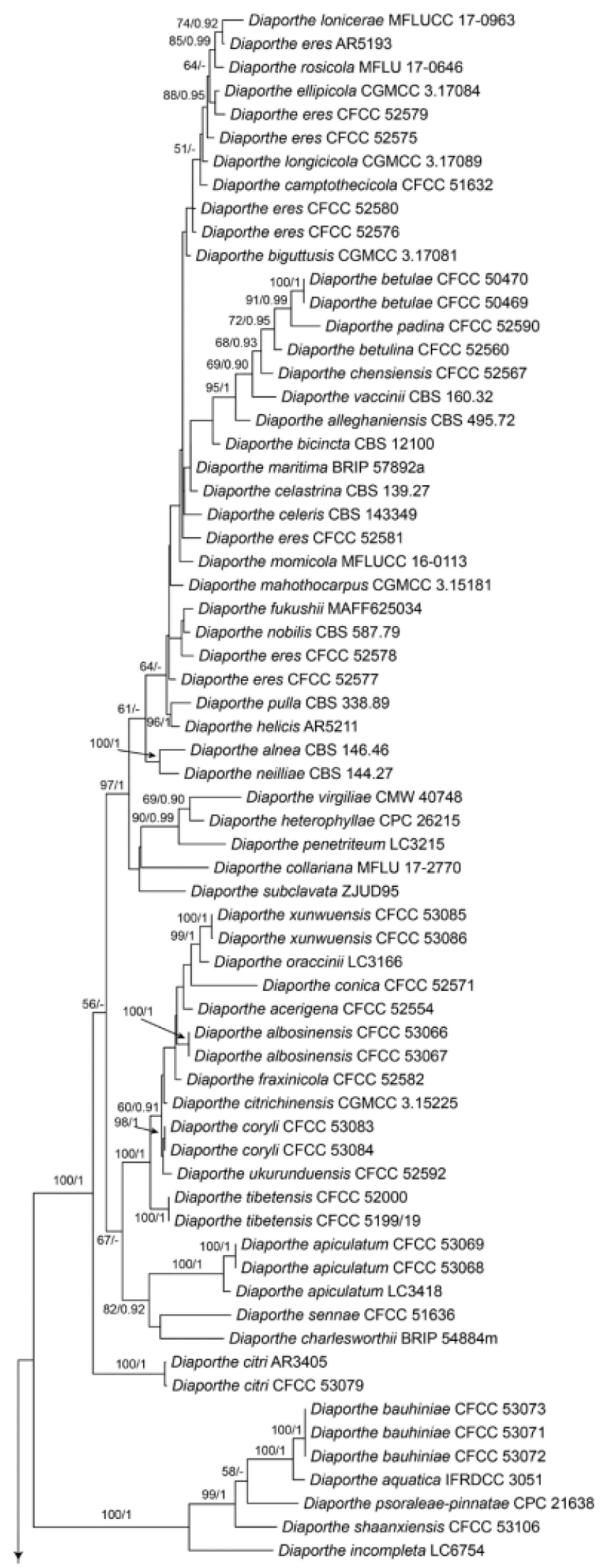

Figure A9. Cont. 


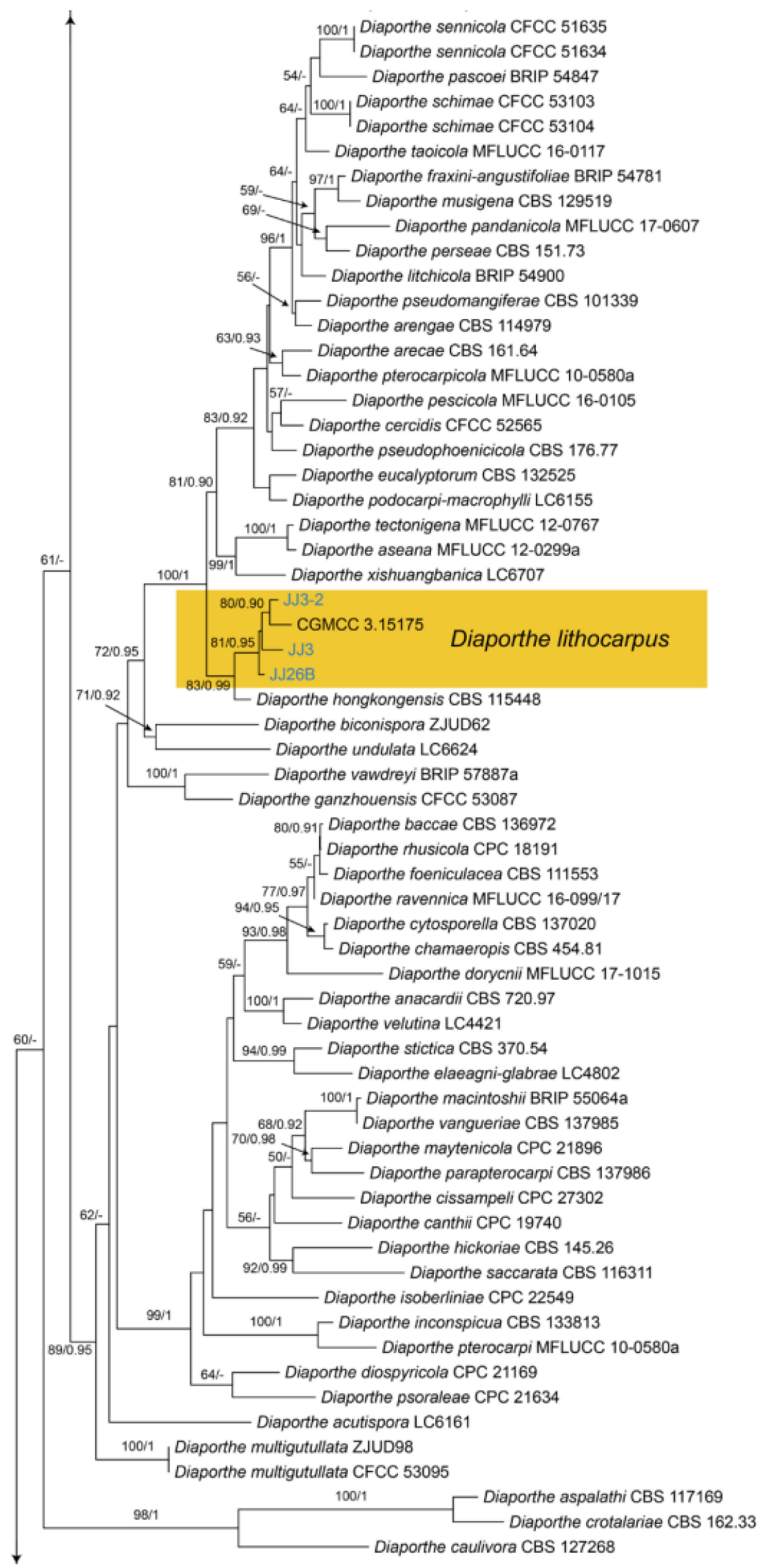

Figure A9. Cont. 


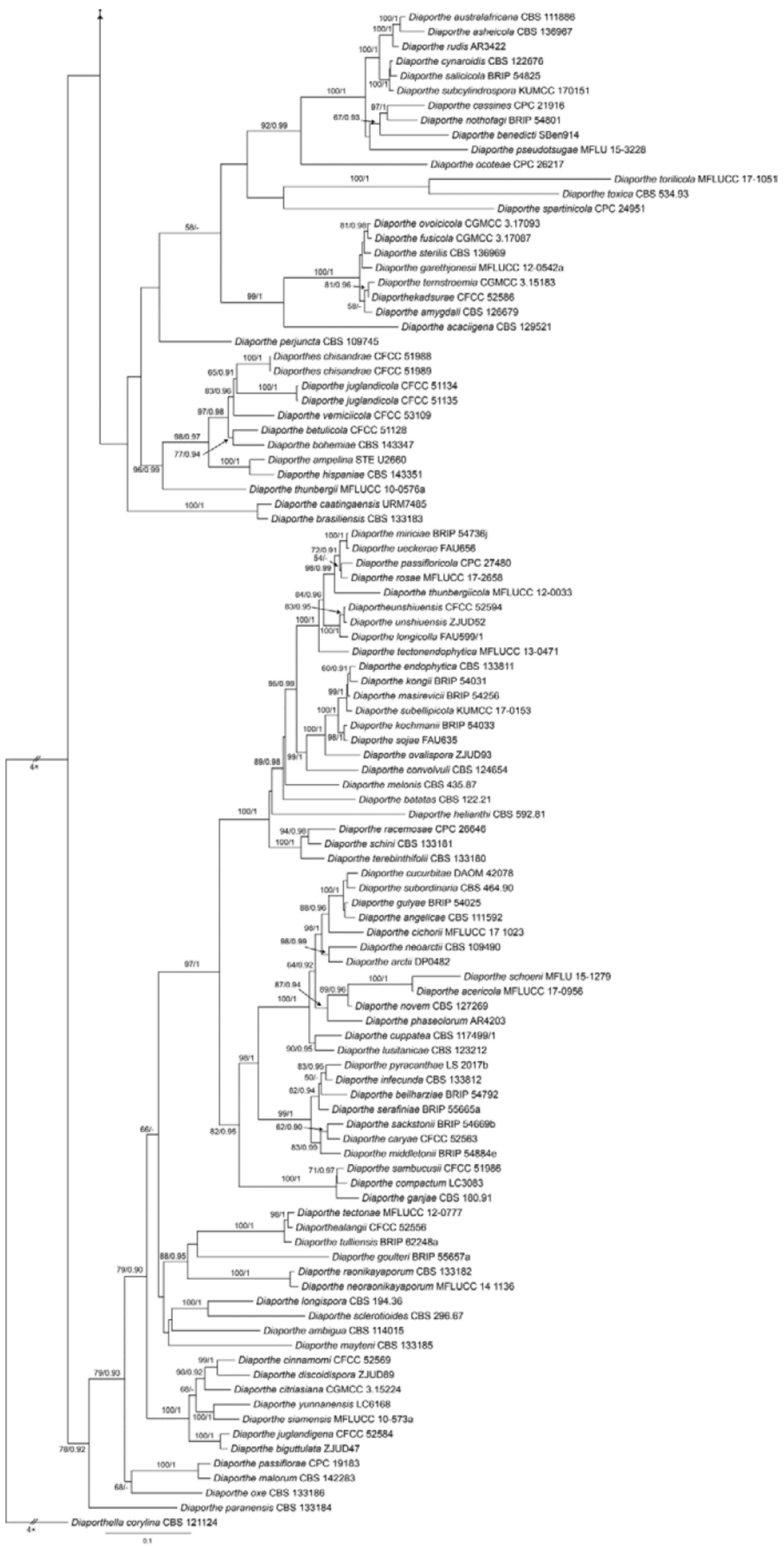

Figure A9. Phylogram generated from RAxML analysis based on combined ITS, cal, his, tef1 and tub2 sequence data of Diaporthe isolates. The tree was rooted to Diaporthella corylina (CBS 121124). The scale bar indicates 0.1 nucleotide changes per site. Isolates from this study are marked in blue, and the identified species is marked in yellow. 


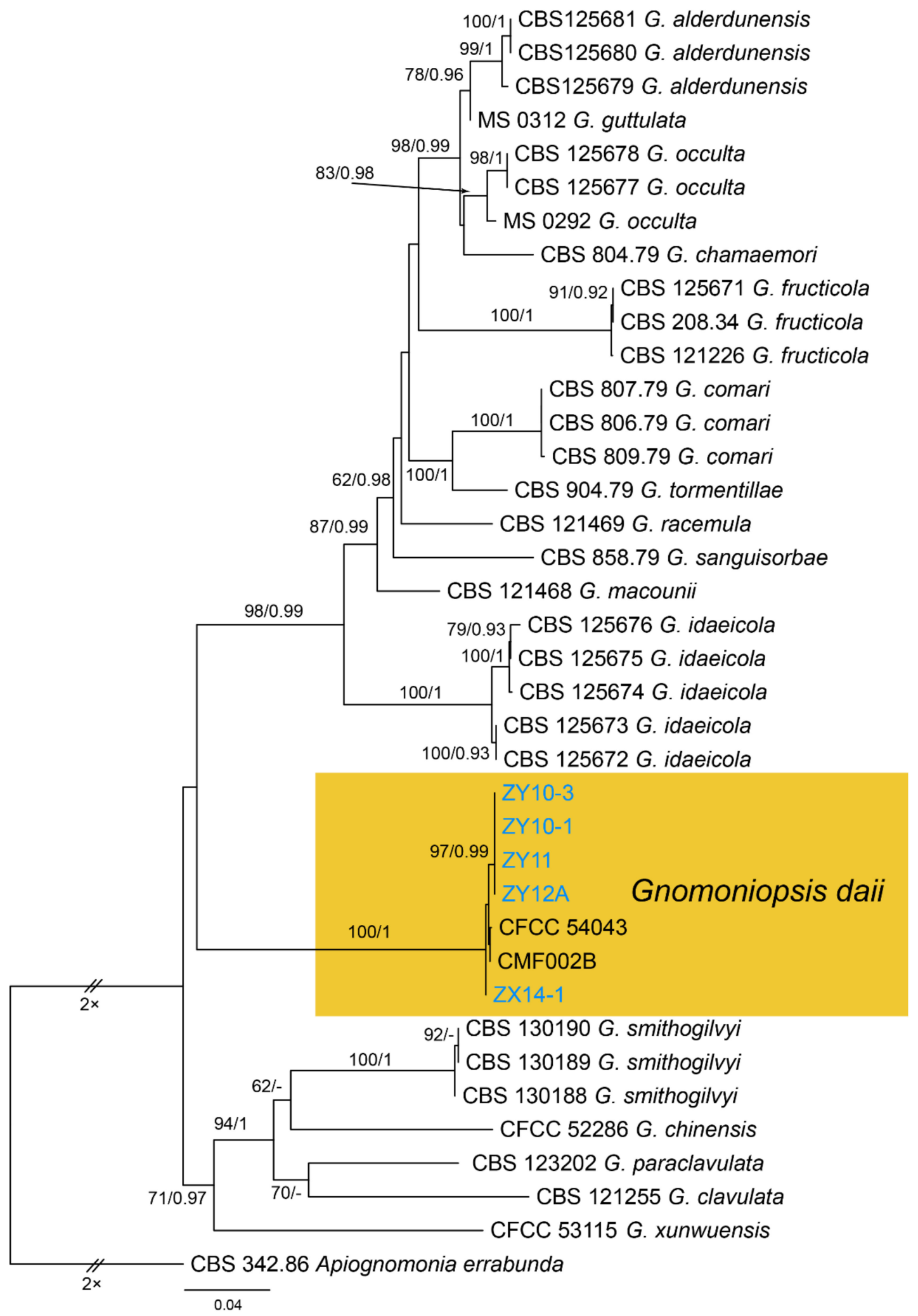

Figure A10. Phylogram generated from RAxML analysis based on combined ITS, tef1 and tub2 sequence data of Gnomoniopsis isolates. The tree was rooted to Apiognomonia errabunda (CBS 342.86). The scale bar indicates 0.04 nucleotide changes per site. Isolates from this study are marked in blue, and the identified species is marked in yellow. 


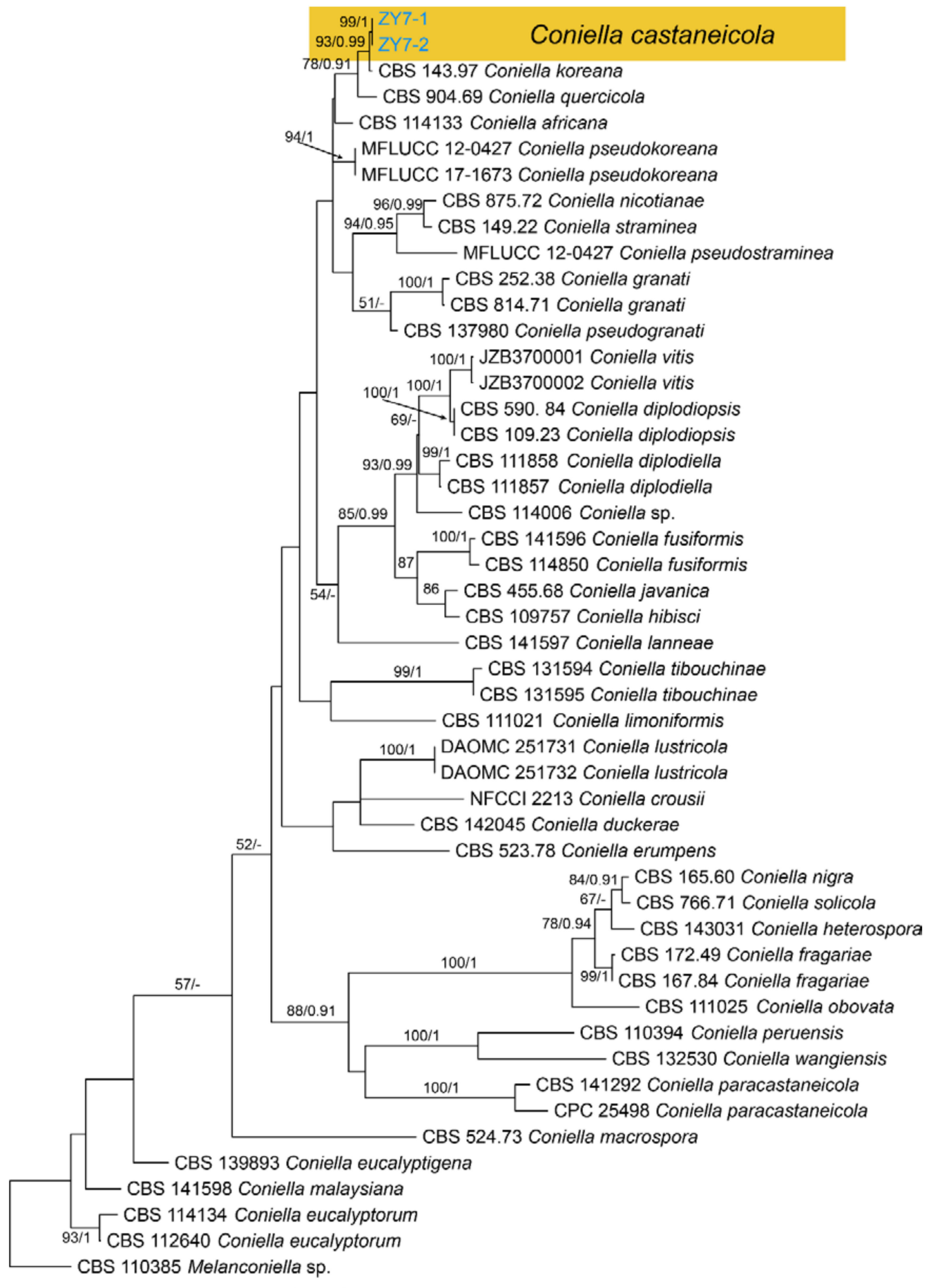

$\overline{0.05}$

Figure A11. Phylogram generated from RAxML analysis based on combined ITS, tef1 and tub2 sequence data of Coniella isolates. The tree was rooted to Melanconiella sp. (CBS 110385). The scale bar indicates 0.05 nucleotide changes per site. Isolates from this study are marked in blue, and the identified species is marked in yellow. 


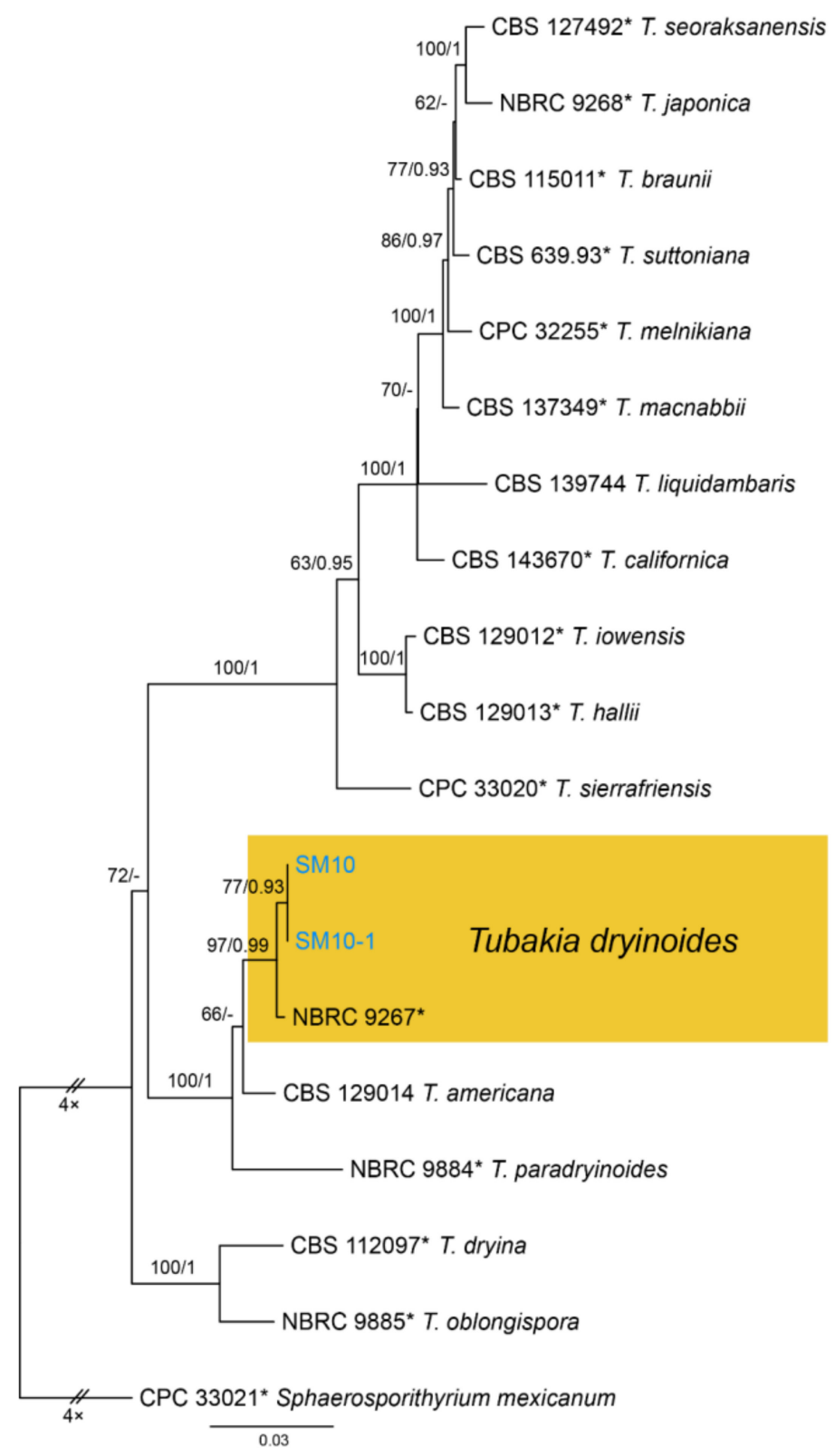

Figure A12. Phylogram generated from RAxML analysis based on combined ITS, tef1 and tub2 sequence data of Tubakia isolates. The tree was rooted to Sphaerosporithyrium mexicanum (CPC 33021). The scale bar indicates 0.03 nucleotide changes per site. Isolates from this study are marked in blue, ex-type strains are marked with *, and the identified species is marked in yellow. 


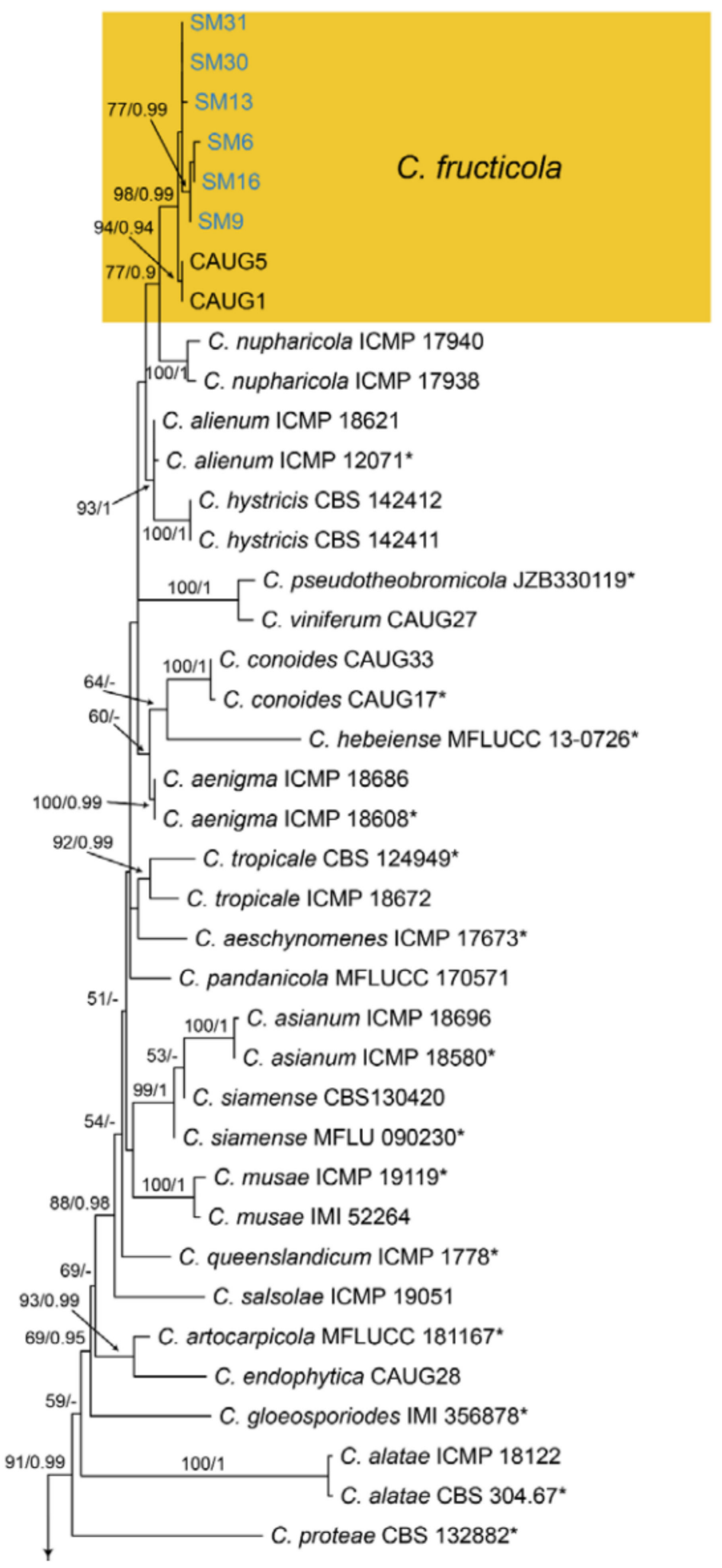

Figure A13. Cont. 


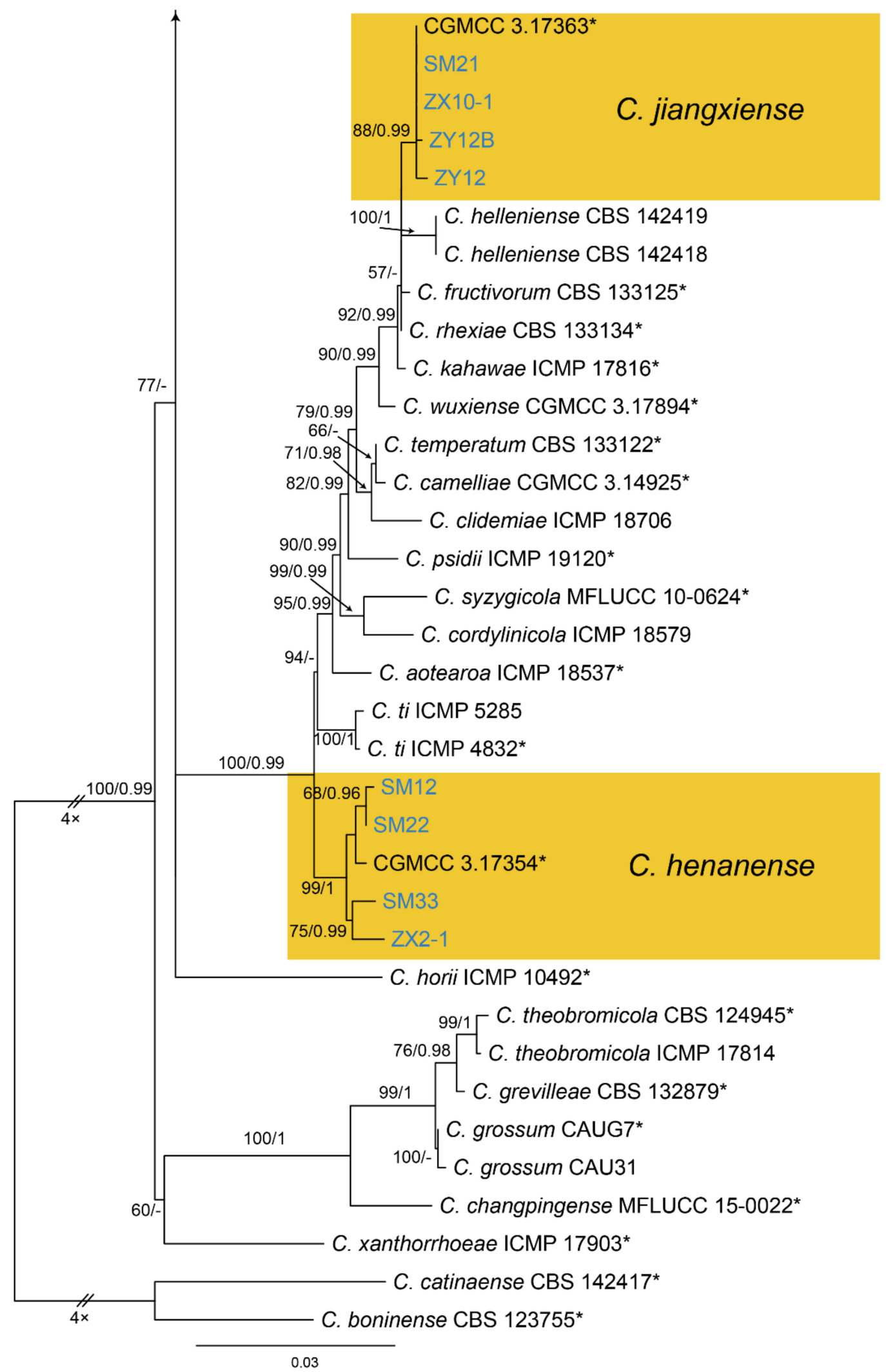

Figure A13. Phylogram generated from RAxML analysis based on combined ITS, act, chs-1, gapdh and tub2 sequence data of Collectrichum gloeosporiodes species complex isolates. The tree was rooted to Collectrichum catinaense (CBS 142417) and C. boninense (CBS 123755). The scale bar indicates 0.03 nucleotide changes per site. Isolates from this study are marked in blue, ex-type strains are marked with *, and the identified species are marked in yellow. 


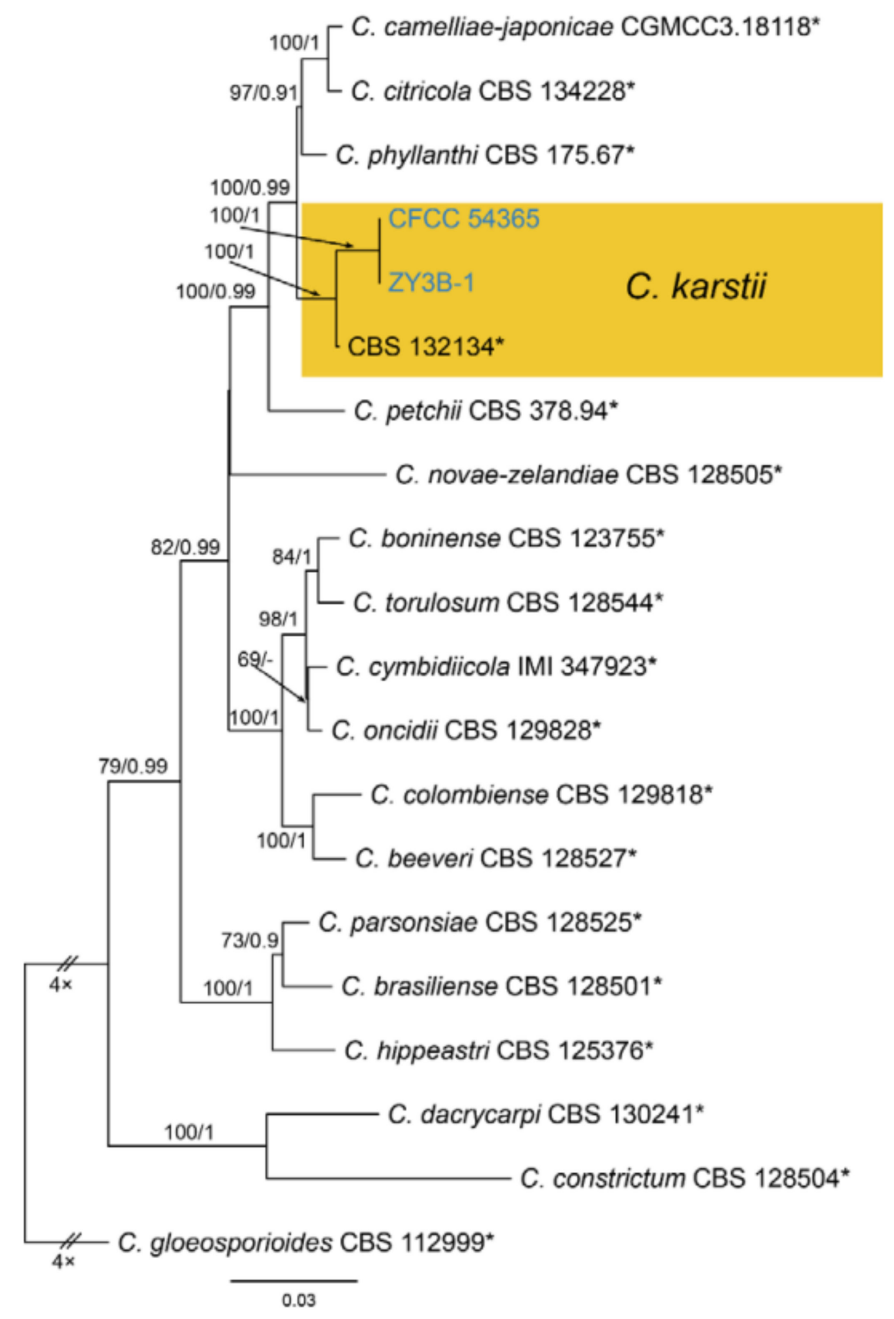

Figure A14. Phylogram generated from RAxML analysis based on combined ITS, act, chs-1, gapdh and $t u b 2$ sequence data of Collectrichum boninense species complex isolates. The tree was rooted to Collectrichum gloeosporiodes (CBS 112999). The scale bar indicates 0.03 nucleotide changes per site. Isolates from this study are marked in blue, ex-type strains are marked with *, and the identified species is marked in yellow. 


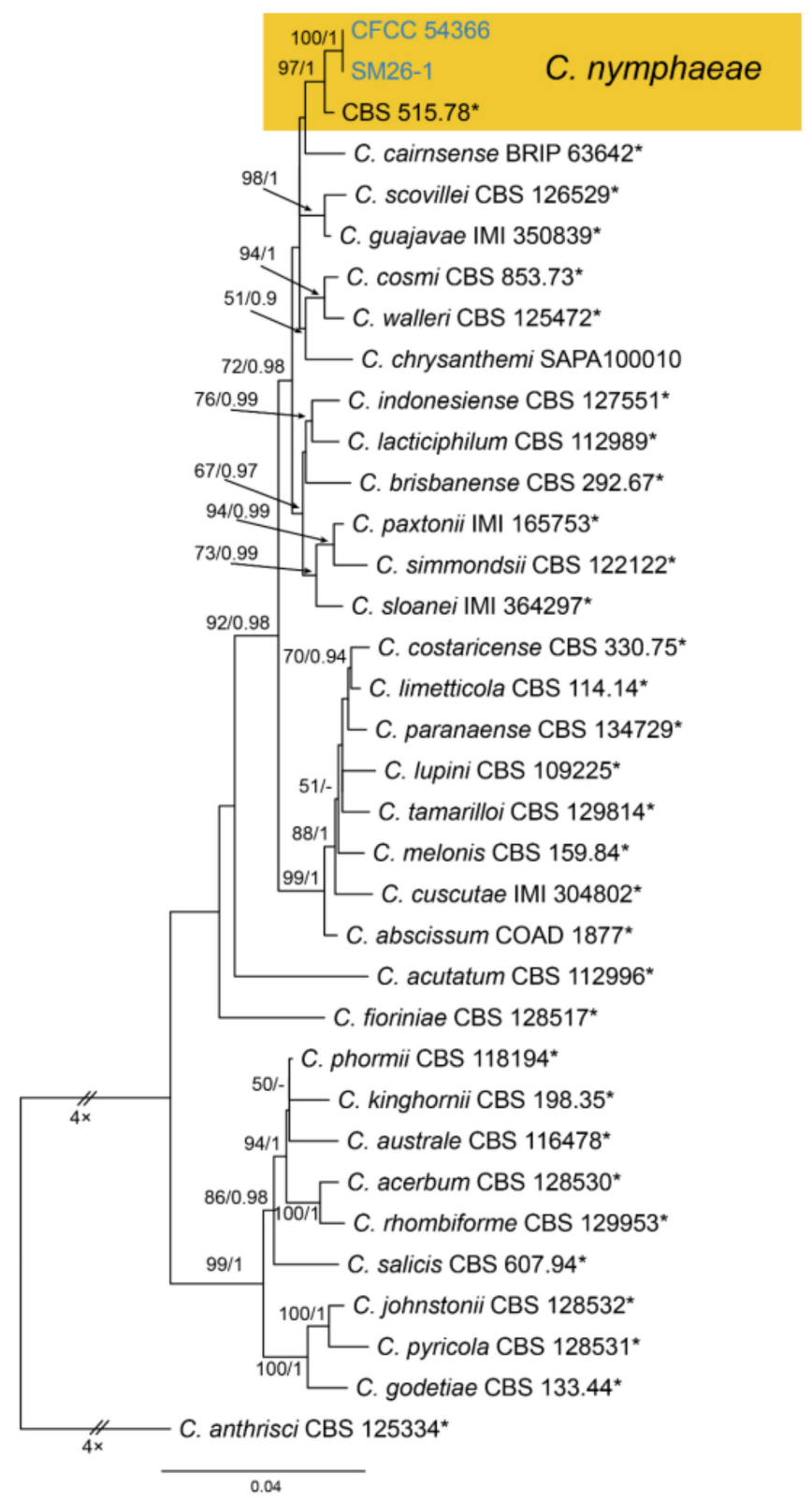

Figure A15. Phylogram generated from RAxML analysis based on combined ITS, act, chs-1, gapdh and $t u b 2$ sequence data of Collectrichum acutatum species complex isolates. The tree was rooted to Collectrichum anthrisci (CBS 125334). The scale bar indicates 0.04 nucleotide changes per site. Isolates from this study are marked in blue, ex-type strains are marked with *, and the identified species is marked in yellow.

\section{References}

1. Anagnostakis, S.L. Chestnut blight: The classical problem of an introduced pathogen. Mycologia 1987, 79, 23-37. [CrossRef]

2. Jiang, N.; Fan, X.L.; Tian, C.M. Identification and pathogenicity of Cryphonectriaceae species associated with chestnut canker in China. Plant Pathol. 2019, 68, 1132-1145. [CrossRef]

3. Rigling, D.; Prospero, S. Cryphonectria parasitica, the causal agent of chestnut blight: Invasion history, population biology and disease control. Mol. Plant. Pathol. 2018, 19, 7-20. [CrossRef] [PubMed]

4. Shuttleworth, L.A.; Walker, D.M.; Guest, D.I. The chestnut pathogen Gnomoniopsis smithogilvyi (Gnomoniaceae, Diaporthales) and its synonyms. Mycotaxon 2016, 130, 929-940. [CrossRef]

5. Visentin, I.; Gentile, S.; Valentino, D.; Gonthier, P.; Tamietti, G.; Cardinale, F. Gnomoniopsis castanea sp. nov. (Gnomoniaceae, Diaporthales) as the causal agent of nut rot in sweet chestnut. J. Plant. Pathol. 2012, 94, 411-419. 
6. Simsek, S.A.; Katircioglu, Y.Z.; Serce, Ç.U.; Cakar, D.; Rigling, D.; Maden, S. Phytophthora species associated with dieback of sweet chestnut in Western Turkey. For. Pathol. 2019, 49, e12533. [CrossRef]

7. Meyer, J.B.; Trapiello, E.; Senn-Irlet, B.; Sieber, T.N.; Cornejo, C.; Aghayeva, D.; González, A.J.; Prosperoa, S. Phylogenetic and phenotypic characterisation of Sirococcus castaneae comb. nov. (synonym Diplodina castaneae), a fungal endophyte of European chestnut. Fungal Biol. 2017, 121, 625-637. [CrossRef]

8. Jiang, N.; Voglmayr, H.; Tian, C.M. New species and records of Coryneum from China. Mycologia 2018, 110, 1172-1188. [CrossRef]

9. Jiang, N.; Yang, Q.; Fan, X.L.; Tian, C.M. Identification of six Cytospora species on Chinese chestnut in China. MycoKeys 2020, 62, 1-25. [CrossRef]

10. Jiang, N.; Fan, X.L.; Crous, P.W.; Tian, C.M. Species of Dendrostoma (Erythrogloeaceae, Diaporthales) associated with chestnut and oak canker diseases in China. MycoKeys 2019, 48, 67-96. [CrossRef]

11. Jiang, N.; Li, J.; Piao, C.G.; Guo, M.W.; Tian, C.M. Identification and characterization of chestnut branch-inhabiting melanocratic fungi in China. Mycosphere 2018, 9, 1268-1289. [CrossRef]

12. Jiang, N.; Phillips, A.J.L.; Zhang, Z.X.; Tian, C.M. Morphological and molecular identification of two novel species of Melanops in China. Mycosphere 2018, 9, 1187-1196. [CrossRef]

13. Doyle, J.J.; Doyle, J.L. Isolation of plant DNA from fresh tissue. Focus 1990, 12, 13-15.

14. Miller, M.A.; Pfeiffer, W.; Schwartz, T. Creating the CIPRES Science Gateway for Inference of Large Phylogenetic Trees; Institute of Electrical and Electronics Engineers: New Orleans, LA, USA, 2010.

15. Ronquist, F.; Huelsenbeck, J.P. MrBayes 3: Bayesian phylogenetic inference under mixed models. Bioinformatics 2003, 19, 1572-1574. [CrossRef] [PubMed]

16. White, T.J.; Bruns, T.; Lee, S.; Taylor, J. Amplification and direct sequencing of fungal ribosomal RNA genes for phylogenetics. PCR Protoc. Guide Methods Appl. 1990, 18, 315-322.

17. Carbone, I.; Kohn, L.M. A method for designing primer sets for speciation studies in filamentous ascomycetes. Mycologia 1999, 91, 553-556. [CrossRef]

18. Templeton, M.D.; Rikkerink, E.H.; Solon, S.L.; Crowhurst, R.N. Cloning and molecular characterization of the glyceraldehyde3-phosphate dehydrogenase-encoding gene and cDNA from the plant pathogenic fungus Glomerella cingulata. Gene 1992, 122, 225-230. [CrossRef]

19. Myllys, L.; Stenroos, S.; Thell, A. New genes for phylogenetic studies of lichenized fungi: Glyceraldehyde-3-phosphate dehydrogenase and beta-tubulin genes. Lichenologist 2002, 34, 237-246. [CrossRef]

20. Glass, N.L.; Donaldson, G.C. Development of primer sets designed for use with the PCR to amplify conserved genes from filamentous ascomycetes. Appl. Environ. Microb. 1995, 61, 1323-1330. [CrossRef]

21. Crous, P.W.; Groenewald, J.Z.; Risède, J.M.; Simoneau, P.; Hywel-Jones, N.L. Calonectria species and their Cylindrocladium anamorphs: Species with sphaeropedunculate vesicles. Stud. Mycol. 2004, 50, 415-430.

22. Liu, Y.J.; Whelen, S.; Hall, B.D. Phylogenetic relationships among ascomycetes: Evidence from an RNA polymerse II subunit. Mol. Biol. Bvol. 1999, 16, 1799-1808. [CrossRef]

23. Damm, U.; Fourie, P.H.; Crous, P.W. Aplosporella prunicola, a novel species of anamorphic Botryosphaeriaceae. Fungal Divers. 2007, $27,35-43$.

24. Ariyawansa, H.A.; Hyde, K.D.; Liu, J.K.; Wu, S.P.; Liu, Z.Y. Additions to Karst Fungi 1: Botryosphaeria minutispermatia sp. nov., from Guizhou Province, China. Phytotaxa 2016, 275, 35-44. [CrossRef]

25. Li, G.Q.; Liu, F.F.; Li, J.Q.; Liu, Q.L.; Chen, S.F. Botryosphaeriaceae from Eucalyptus plantations and adjacent plants in China. Persoonia 2018, 40, 63-95. [CrossRef]

26. Liang, L.Y.; Jiang, N.; Chen, W.Y.; Liang, Y.M.; Tian, C.M. Botryosphaeria qinlingensis sp. nov. causing oak frogeye leaf spot in China. Mycotaxon 2019, 134, 463-473. [CrossRef]

27. Norphanphoun, C.; Hongsanan, S.; Gentekaki, E.; Chen, Y.J.; Kuo, C.H.; Hyde, K.D. Differentiation of species complexes in Phyllosticta enables better species resolution. Mycosphere 2020, 11, 2542-2628. [CrossRef]

28. De Hoog, G.S.; Hermanides-Nijhof, E.J. Aureobasidium and allied genera. Stud. Mycol. 1977, 15, $166-173$.

29. Zalar, P.; Gostinčar, C.; De Hoog, G.S.; Uršič, V.; Sudhadham, M.; Gunde-Cimerman, N. Redefinition of Aureobasidium pullulans and its varieties. Stud. Mycol. 2008, 61, 21-38. [CrossRef]

30. Arzanlou, M.; Khodaei, S. Aureobasidium iranianum, a new species on bamboo from Iran. Mycosphere 2012, 3, 404-408. [CrossRef]

31. Peterson, S.W.; Manitchotpisit, P.; Leathers, T.D. Aureobasidium thailandense sp. nov. isolated from leaves and wooden surfaces. Int. J. Syst. Evol. Micr. 2013, 63, 790-795. [CrossRef]

32. Jiang, N.; Liang, Y.M.; Tian, C.M. Aureobasidium pini sp. nov. from pine needle in China. Phytotaxa 2019, 402, 199-206. [CrossRef]

33. Aveskamp, M.M.; Verkley, G.J.; de Gruyter, J.; Murace, M.A.; Perello, A.; Woudenberg, J.H.; Groenewald, J.Z.; Crous, P.W. DNA phylogeny reveals polyphyly of Phoma section Peyronellaea and multiple taxonomic novelties. Mycologia 2009, 101, 363-382. [CrossRef]

34. Chen, Q.; Jiang, J.R.; Zhang, G.Z.; Cai, L.; Crous, P.W. Resolving the Phoma enigma. Stud. Mycol. 2015, 82, 137-217. [CrossRef]

35. Chen, Q.; Hou, L.W.; Duan, W.J.; Crous, P.W.; Cai, L. Didymellaceae revisited. Stud. Mycol. 2017, 87, 105-159. [CrossRef]

36. Hou, L.W.; Hernández-Restrepo, M.; Groenewald, J.Z.; Cai, L.; Crous, P.W. Citizen science project reveals high diversity in Didymellaceae (Pleosporales, Dothideomycetes). MycoKeys 2020, 65, 49-99. [CrossRef] 
37. Hou, L.W.; Groenewald, J.Z.; Pfenning, L.H.; Yarden, O.; Crous, P.W.; Cai, L. The phoma-like dilemma. Stud. Mycol. 2020, 96, 309-396. [CrossRef]

38. Dai, D.Q.; Jiang, H.B.; Tang, L.Z.; Bhat, D.J. Two new species of Arthrinium (Apiosporaceae, Xylariales) associated with bamboo from Yunnan, China. Mycosphere 2016, 7, 1332-1345. [CrossRef]

39. Wang, M.; Tan, X.M.; Liu, F.; Cai, L. Eight new Arthrinium species from China. MycoKeys 2018, 34, 1-24. [CrossRef]

40. Pintos, Á.; Alvarado, P.; Planas, J.; Jarling, R. Six new species of Arthrinium from Europe and notes about A. caricicola and other species found in Carex spp. hosts. MycoKeys 2019, 49, 15-48. [CrossRef]

41. Yan, H.; Jiang, N.; Liang, L.Y.; Yang, Q.; Tian, C.M. Arthrinium trachycarpum sp. nov. from Trachycarpus fortunei in China. Phytotaxa 2019, 400, 203-210. [CrossRef]

42. Jiang, N.; Liang, Y.M.; Tian, C.M. A novel bambusicolous fungus from China, Arthrinium chinense (Xylariales). Sydowia 2020, 72, 77-83.

43. Liu, F.; Bonthond, G.; Groenewald, J.Z.; Cai, L.; Crous, P.W. Sporocadaceae, a family of coelomycetous fungi with appendagebearing conidia. Stud. Mycol. 2019, 92, 287-415. [CrossRef]

44. Xie, B.D. Chestnut Diseases; China Forestry Publishing: Beijing, China, 1998; pp. 1-188.

45. Li, J.W.; Liu, J.K.; Bhat, D.J.; Chomnunti, P. Molecular phylogenetic analysis reveals two new species of Discosia from Italy. Phytotaxa 2015, 203, 37-46. [CrossRef]

46. Tangthirasunun, N.; Silar, P.; Bhat, D.J.; Maharachchikumbura, S.S.; Wijayawardene, N.W.; Bahkali, A.H.; Hyde, K.D. Morphology and phylogeny of two appendaged genera of coelomycetes: Ciliochorella and Discosia. Sydowia 2015, 67, 217-226.

47. De Silva, N.I.; Maharachchikumbura, S.S.; Bhat, D.J.; Phookamsak, R.; Al-Sadi, A.M.; Lumyong, S.; Hyde, K.D. Monochaetia sinensis sp. nov. from Yunnan Province in China. Phytotaxa 2018, 375, 59-69. [CrossRef]

48. Crous, P.W.; Schumacher, R.K.; Wingfield, M.J.; Akulov, A.; Bulgakov, T.S.; Carnegie, A.J.; Jurjević, Ž.; Decock, C.; Denman, S.; Lombard, L.; et al. New and interesting fungi. 1. Fungal Syst. Evol. 2019, 1, 169-215. [CrossRef]

49. Maharachchikumbura, S.S.N.; Guo, L.D.; Cai, L.; Chukeatirote, E.; Wu, W.; Sun, X.; Crous, P.W.; Bhat, D.J.; Mckenzie, E.; Bahkali, A. A multi-locus backbone tree for Pestalotiopsis, with a polyphasic characterization of 14 new species. Fungal Divers. 2012, 56, 95-129. [CrossRef]

50. Maharachchikumbura, S.S.; Hyde, K.D.; Groenewald, J.Z.; Xu, J.; Crous, P.W. Pestalotiopsis revisited. Stud. Mycol. 2014, 79, 121-186. [CrossRef]

51. Bezerra, J.D.P.; Machado, A.R.; Firmino, A.L.; Rosado, A.W.C.; de Souza, C.A.F.; de Souza-Motta, C.M.; Freire, K.T.L.d.S.; Paiva, L.M.; Magalhães, O.M.C.; Pereira, O.L.; et al. Mycological diversity description I. Acta Bot. Bras. 2018, 32, 656-666. [CrossRef]

52. Yurchenko, E.; Belomesyatseva, D. Robillarda sessilis, a rare coelomycete isolated from Scots pine seedlings. Acta Mycol. 2010, 45, 27-32. [CrossRef]

53. Gao, Y.H.; Sun, W.; Su, Y.Y.; Cai, L. Three new species of Phomopsis in Gutianshan nature reserve in China. Mycol. Prog. 2014, 13, 111-121. [CrossRef]

54. Jiang, N.; Tian, C.M. An emerging pathogen from rotted chestnut in China: Gnomoniopsis daii sp. nov. Forests $2019,10,1016$. [CrossRef]

55. Jiang, N.; Liang, L.Y.; Tian, C.M. Gnomoniopsis chinensis (Gnomoniaceae, Diaporthales), a new fungus causing canker of Chinese chestnut in Hebei Province, China. MycoKeys 2020, 67, 19-32. [CrossRef] [PubMed]

56. Jiang, N.; Fan, X.L.; Tian, C.M.; Crous, P.W. Reevaluating Cryphonectriaceae and allied families in Diaporthales. Mycologia 2020, 112, 267-292. [CrossRef]

57. Fan, X.L.; Bezerra, J.D.; Tian, C.M.; Crous, P.W. Families and genera of diaporthalean fungi associated with canker and dieback of tree hosts. Persoonia 2018, 40, 119-134. [CrossRef]

58. Senanayake, I.C.; Crous, P.W.; Groenewald, J.Z.; Maharachchikumbura, S.S.; Jeewon, R.; Phillips, A.J.; Bhat, J.D.; Perera, R.H.; Li, Q.R.; Li, W.J.; et al. Families of Diaporthales based on morphological and phylogenetic evidence. Stud. Mycol. 2017, 86, 217-296. [CrossRef]

59. Senanayake, I.C.; Jeewon, R.; Chomnunti, P.; Wanasinghe, D.N.; Norphanphoun, C.; Karunarathna, A.; Pem, D.; Perera, R.H.; Camporesi, E.; Eric, H.C.; et al. Taxonomic circumscription of Diaporthales based on multigene phylogeny and morphology. Fungal Divers. 2018, 93, 241-443. [CrossRef]

60. Alvarez, L.V.; Groenewald, J.Z.; Crous, P.W. Revising the Schizoparmaceae: Coniella and its synonyms Pilidiella and Schizoparme. Stud. Mycol. 2016, 85, 1-34. [CrossRef]

61. Sutton, B.C. The Coelomycetes. In Fungi Imperfecti with Pycnidia, Acervuli and Stromata; Commonwealth Mycological Institute: Kew, UK, 1980.

62. Braun, U.; Nakashima, C.; Crous, P.W.; Groenewald, J.Z.; Moreno-Rico, O.; Rooney-Latham, S.; Blomquist, C.L.; Haas, J.; Marmolejo, J. Phylogeny and taxonomy of the genus Tubakia s. lat. Fungal Syst. Evol. 2018, 1, 41-99. [CrossRef]

63. Prihastuti, H.; Cai, L.; Chen, H.; McKenzie, E.H.C.; Hyde, K.D. Characterization of Colletotrichum species associated with coffee berries in northern Thailand. Fungal Divers. 2009, 39, 89-109.

64. Farr, D.F.; Rossman, A.Y. Fungal Databases, U.S. National Fungus Collections, ARS, USDA. Available online: https://nt.ars-grin. gov/fungaldatabases/ (accessed on 22 December 2020). 
65. Liu, F.; Weir, B.S.; Damm, U.; Crous, P.W.; Wang, Y.; Liu, B.; Wang, M.; Zhang, M.; Cai, L. Unravelling Colletotrichum species associated with Camellia: Employing ApMat and GS loci to resolve species in the C. gloeosporioides complex. Persoonia 2015, 35, 63-86. [CrossRef] [PubMed]

66. Li, H.; Zhou, G.Y.; Qi, X.Y.; Jiang, S.Q. First report of Colletotrichum henanense causing anthracnose on tea-oil trees in China. Plant Dis. 2018, 102, 1040. [CrossRef]

67. Jayawardena, R.S.; Hyde, K.D.; Damm, U.; Cai, L.; Liu, M.; Li, X.H.; Zhang, W.; Zhao, W.S.; Yan, J.Y. Notes on currently accepted species of Colletotrichum. Mycosphere 2016, 7, 1192-1260. [CrossRef]

68. Yang, Y.L.; Cai, L.; Yu, Z.; Liu, Z.; Hyde, K.D. Colletotrichum species on Orchidaceae in southwest China. Cryptogamie Mycol. 2011, 32, 229-253.

69. Hyde, K.D.; Norphanphoun, C.; Maharachchikumbura, S.S.N.; Bhat, D.J.; Jones, E.B.G.; Bundhun, D.; Chen, Y.J.; Boonmee, S.; Calabon, M.; Chaiwan, N.; et al. Refined families of Sordariomycetes. Mycosphere 2020, 11, 305-1059. [CrossRef]

70. Weir, B.S.; Johnston, P.R.; Damm, U. The Colletotrichum gloeosporioides species complex. Stud Mycol. 2012, 73, 115-180. [CrossRef] 